\title{
DIRECTORS' DUTIES TO CREDITORS: POWER IMBALANCE AND THE FINANCIALLY DISTRESSED CORPORATION
}

\author{
Jonathan C. Lipson
}

This Article questions the widely held view that the fiduciary duties that corporate directors ordinarily owe to or for the benefit of shareholders should "shift" to creditors when the corporation is in financial distress. This view suffers from two important flaws. First, it mistakenly assumes a strong connection between duty and priority in right of payment. Thus, the thinking goes, as the corporation approaches insolvency, creditors should displace shareholders as the residual claimants, to whom duties should run. While this may make sense when a corporation liquidates, it ignores the fact that priority is a distributional doctrine, and therefore functions very differently than does duty. Moreover, priority is often an unstable and opaque doctrine, and thus a poor trigger of duty.

The second, and more important, mistake is that linking priority and duty causes us to ignore the deeper normative concerns that should animate duty in the corporate context. These normative concerns usually respond to power imbalances expressed as disparities of volition (voluntariness), cognition (information), and exit (access to secondary markets).

On this view, it is apparent that not all creditors of the distressed corporation are equal. Creditors who lack volition, cognition, and exit-and thus should benefit from directorial duties-might include tort creditors, terminated at-will employees, taxing authorities and certain trade creditors. Other creditors-chiefly banks and bondholders-neither need nor deserve directorial duties. They typically benefit from high levels of volition, cognition, and exit, as expressed in both the heavily negotiated contracts that govern their relationships with the corporate debtor and their access to well-established secondary markets. This Article contains a proposal for adjusting directors' duties accordingly.

* Associate Professor of Law, University of Baltimore School of Law. A prior draft of this paper was presented at the 2002 Law and Society Conference. It has benefited from the comments of, or discussions with, William Allen, Carl Bjerre, Fred Brown, Joe Franco, Eric Gouvin, Claire Hill, Bob Lawless, Kathleen Noonan, Lynn Stout, Brian Robinson, and Jay Westbrook. Jennifer Jordan, Richard Smith, and Catherine Worthington provided valuable research assistance, and Tracy Casadio and the staff of the UCLA Law Review provided valuable editorial assistance with this Article. Errors and omissions are mine alone. 을 2003 Jonathan C. Lipson, all rights reserved. 


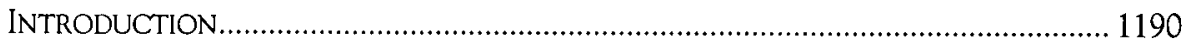

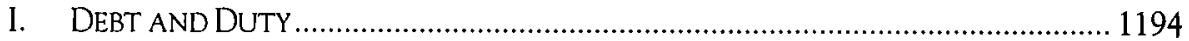

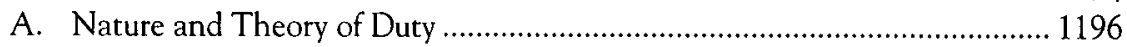

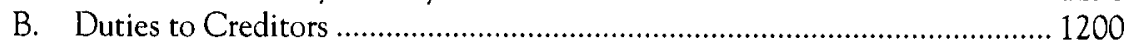

1. The Event/Condition Paradigm............................................................ 1203

a. The Trust Fund Cases.................................................................... 1203

b. Credit Lyonnais -The "Vicinity" of Insolvency............................... 1208

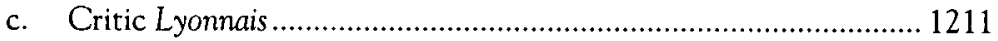

2. The Efficiency Paradigm ........................................................................ 1213

a. Shareholder Maximization—No Shift ………………………….... 1214

b. Entity Maximization-Expanding Duties ...................................... 1218

c. Creditor Maximization-True Shift............................................... 1225

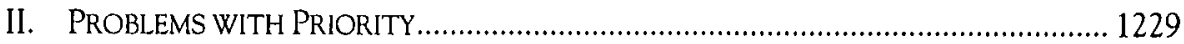

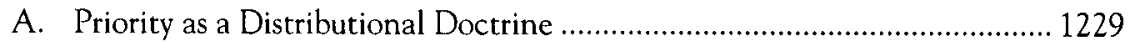

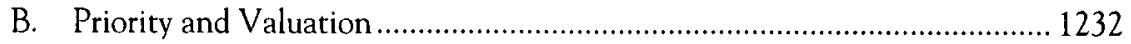

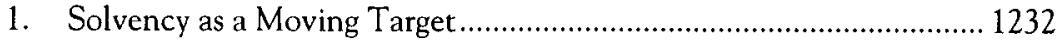

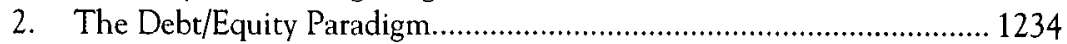

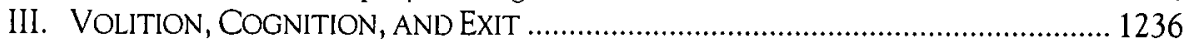

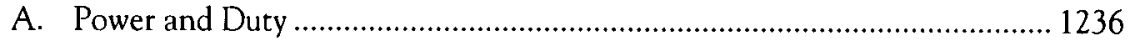

B. Volition, Cognition, and Exit: Contract and Creditors ............................... 1242

1. Low VCE Creditors.......................................................................... 1245

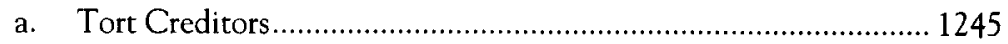

b. Terminated Employees .................................................................. 1247

c. Taxing Authorities ........................................................................ 1248

d. Certain Trade Creditors .............................................................. 1248

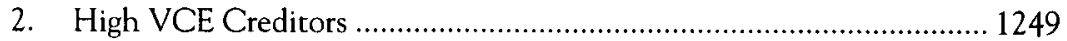

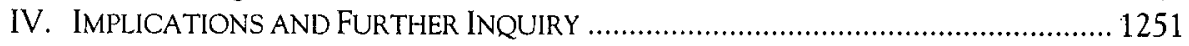

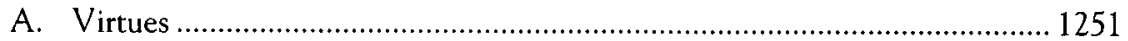

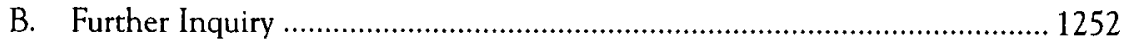

1. The Proper Role of Priority and Contract ........................................... 1252

2. Problems with Volition, Cognition, and Exit..................................... 1253

3. Contingent and Unliquidated Claims ............................................... 1254

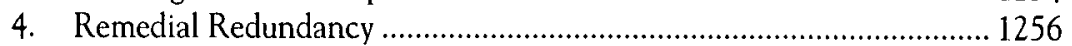

5. The Special Problem of Securities Fraud ...........................................1257

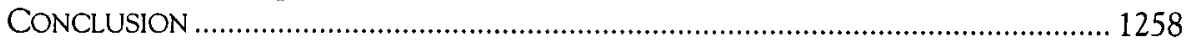

\section{INTRODUCTION}

It has become commonplace-perhaps trite-to observe that once a corporation is in financial distress, duties of care and loyalty that ordinarily run solely to or for the benefit of shareholders "shift" to corporate creditors. This observation is generally rooted in a line of cases beginning with the 
1991 Credit Lyonnais decision.' It has yielded a healthy amount of analysis, most of it focusing on what it means for a corporation to be distressed such that duty begins its shift. ${ }^{2}$

1. See Credit Lyonnais Bank Nederland, N.V. v. Pathe Communications Corp., No. 12150, 1991 Del. Ch. LEXIS 215, at *108-*09 (Del. Ch. Dec. 30, 1991). Cases following Credit Lyonnais include: Miramar Res., Inc. v. Schultz (In re Schultz), 208 B.R. 723, 729 (Bankr. M.D. Fla. 1997); Official Comm. of Unsecured Creditors of Buckhead Am. Corp. v. Reliance Capital Group (In re Buckhead Am. Corp.), 178 B.R. 956, 968 (D. Del. 1994); Geyer v. Ingersoll Publ'ns Co., 621 A.2d 784, 787 (Del. Ch. 1992); Brandt v. Hicks, Muse \& Co. (In re Healthco Int'l, Inc.), 208 B.R. 288, 300 (Bankr. D. Mass. 1997); Official Comm. of Unsecured Creditors of Hechinger Inv. Co. of Del. v. Fleet Retail Fin. Group (In re Hechinger Inv. Co. of Del. ), 274 B.R. 71, 89 (D. Del. 2002). As discussed in Part I.B.1.a., infra, decisions linking distress and directorial duties to creditors well precede the 1991 Credit Lyonnais opinion. As the most controversial of the decisions, however, Credit Lyonnais has received the most attention.

2. See, e.g., Christopher L. Barnett, Healthco and the "Insolvency Exception": An Unnecessary Expansion of the Doctrine?, 16 BANKR. DEV. J. 441, 465 (2000); Royce de R. Barondes, Fiduciary Duties of Officers and Directors of Distressed Corporations, 7 GEO. MASON L. REV. 45, 101-02 (1998); Norwood P. Beveridge, Jr., Does a Corporation's Board of Directors Owe a Fiduciary Duty to Its Creditors?, 25 ST. MARY'S L.J. 589 (1994); Stephen H. Case, Fiduciary Duty of Corporate Directors and Officers, Resolution of Conflicts Between Creditors and Shareholders, and Removal of Directors by Dissident Shareholders in Chapter 11 Cases, in WILLIAMSBURG CONFERENCE ON BANKRUPTCY 373, 391 (ALI-ABA Invitational Conference 1988); Richard M. Cieri et al., The Fiduciary Duties of Directors of Financially Troubled Companies, 3 J. BANKR. L. \& PRAC. 405, 42122 (1994); Lewis U. Davis, Jr. et al., Corporate Reorganization in the 1990s: Guiding Directors of Troubled Corporations Through Uncertain Territory, 47 BUS. LAw. 1, 14-16 (1991); Laura Lin, Shift of Fiduciary Duty upon Corporate Insolvency: Proper Scope of Directors' Duty to Creditors, 46 VAND. L. REV. 1485, 1524 (1993); Harvey R. Miller, Corporate Governance in Chapter 11: The Fiduciary Relationship Between Directors and Stockholders of Solvent and Insolvent Corporations, 23 SETON HALL L. REV. 1467, 1513-15 (1993); Robert B. Millner, What Does It Mean for Directors of Financially Troubled Corporations to Have Fiduciary Duties to Creditors?, 9 J. BANKR. L. \& PRAC. 201, 224-25 (2000); C. Robert Morris, Directors' Duties in Nearly Insolvent Corporations: A Comment on Credit Lyonnais, 19 J. CORP. L. 61 (1993); Brent Nicholson, Recent Delaware Case Law Regarding Director's Duties to Bondholders, 19 DEL. J. CORP. L. 573, 575 (1994); Joseph Jude Norton, Relationship of Shareholders to Corporate Creditors upon Dissolution: Nature and Implications of the "Trust Fund" Doctrine of Corporate Assets, 30 BuS. LAw. 1061, 1078-79 (1975); Ramesh K.S. Rao et al., Fiduciary Duty a la Lyonnais: An Economic Perspective on Corporate Govemance in a Financially-Distressed Firm, 22 J. CoRP. L. 53, 64-76 (1996); Mike Roberts, The Conundrum of Directors' Duties in Nearly Insolvent Corporations, 23 MEM. ST. U. L. REv. 273, 284 (1993); Andrew D. Shaffer, Corporate Fiduciary-Insolvent: The Fiduciary Relationship Your Corporate Law Professor (Should Have) Wamed You About, 8 AM. BANKR. INST. L. REV. 479 (2000); Ann E. Conaway Stilson, Reexamining the Fiduciary Paradigm at Corporate Insolvency and Dissolution: Defining Directors' Duties to Creditors, 20 DEL. J. CORP. L. 1, 121-22 (1995); Gregory V. Varallo \& Jesse A. Finkelstein, Fiduciary Obligations of Directors of the Financially Troubled Company, 48 BUS. LAW. 239, 239-40 (1992); Rima Fawal Hartman, Note, Situation-Specific Fiduciary Duties for Conporate Directors: Enforceable Obligations or Toothless Ideals?, 50 WASH. \& LEE L. REV. 1761, 1766 (1993); Vladimir Jelisavcic, Comment, Corporate Law-A Safe Harbor Proposal to Define the Limits of Directors' Fiduciary Duty to Creditors in the "Vicinity of Insolvency": Credit Lyonnais v. Pathe, 18 J. CoRP. L. 145, 148-50 (1992); Stephen R. McDonnell, Comment, Geyer v. Ingersoll Publications Co.: Insolvency Shifts Directors' Burden From Shareholders to Creditors, 19 DEL. J. CORP. L. 177, 210 (1994). Some of the issues raised by Credit Lyonnais were anticipated in Peter F. Coogan et al., Panel Discussion: The Problems of the Sinking Ship, 31 Bus. LAw. 1371 (1976). 
Yet, by organizing our analysis around the economics of distress ${ }^{3}$ - making a fetish of solvency-we err in two ways. First, we assume that there is, or should be, some strong correlation between duty and priority in right of payment. This follows from the standard account of directorial duties to creditors: As the corporation becomes financially distressed, creditors become its residual claimants, and are in a sense subrogated to the rights and privileges of shareholders, who no longer have an economic stake in the corporation. This may make sense when the insolvent corporation liquidates, since creditors will be the residual claimants on a standard theory of priority. But in most cases, this analysis is incomplete, if only because most large distresssed corporations do not liquidate; they reorganize.

More importantly, linking duty and priority is problematic because it causes us to ignore the deeper normative concerns that generally animate duty in the corporate context. Priority, in other words, becomes an awkward proxy for the real reasons we should (or should not) recognize directorial duties. Some of these reasons for recognizing duty can be gleaned from the "nexus of contracts" debate, the principal corporate law discussion of the last twenty years. In essence, this debate considers whether duty exists at all in the corporate context, and if so, whether that is a good thing. On the one hand, contractarians argue that duty is illusory, since a corporation is nothing more than a nexus of contractual relationships. Anticontractarians, on the other hand, reject this position, arguing that not all obligations in the corporate context are contractual. More recently, the debate has transformed somewhat, and now considers the role that social norms play in this context.

The nexus of contracts debate is, in many ways, really about three kinds of power imbalance. Contractarians would argue that the only power imbalance that matters arises if a corporate stakeholder lacks "exit"-a secondary market into which the stakeholder can sell its claims against the corporation. Anticontractarians would argue that imbalances of volition (voluntariness) and cognition (information) also warrant imposition of an extracontractual duty. ${ }^{4}$ Curiously, the voluminous literature on directorial

3. This Article intentionally orients its analysis around the concept of "distress" rather than "insolvency." "Insolvency" connotes a level of precision that I think is absent from most discussions of directors' duties to creditors. Indeed, I argue below that insolvency may be difficult, if not impossible, to determine. See the discussion at Il.B.1., infra. Distress is more appropriate because it does not purport to be precise. It also reflects the view expressed in Credit Lyonnais that duties may arise prior to insolvency.

4. The terms "volition" and "cognition" are somewhat loaded. I use these terms in a common sense way to refer to "voluntariness" and "information access," respectively. I am mindful, however, of the fact that these terms could imply a much wider range of meanings. 
duties to creditors has yet to recognize the role that volition, cognition, and exit should play in this context.

This Article remedies that failure. The thesis of the Article is that directorial duties should not be governed exclusively by priority in right of payment. Rather, duties to creditors should be informed by the concerns that ordinarily animate duty in the corporate context-imbalances of volition, cognition, and exit (VCE). On this view, not all creditors of the distressed corporation are equal. In the case of large corporations there will often be wide disparities in the volition, cognition, and exit enjoyed by creditors. Banks and certain bondholders-usually the most vocal members of the claque calling for duties to creditors-typically have, or have access to, significant amounts of information about the debtor. Robust secondary markets give banks and bondholders ample opportunity to exit the corporate relationship if they are unhappy with the debtor's performance. It is not clear how a fiduciary duty would be anything more than a windfall for these sophisticated creditors (whom I will occasionally refer to as "high VCE creditors"). They should be limited to the contractual rights they have (probably laboriously) negotiated.

Yet, it is equally clear that many creditors will have little or no volition, cognition, or exit (I will refer to these as "low VCE creditors"). It is difficult, for example, to characterize tort claimants or taxing authorities as having contractual claims against the debtor. Nor do they have access to secondary markets into which they can sell their positions vis-à-vis the debtor. Rules against champerty and maintenance, for example, typically prohibit tort and wage claimants from selling their claims against the debtor.

\footnotetext{
"Volition," for example, might mean the capacity to act, or action itself. See Robert Audi, Volition, Intention, and Responsibility, 142 U. PA. L. REV. 1675, 1676 (1994) ("We might say, in line with both philosophical tradition and common speech, that volitions are acts of will....") (emphasis omitted). I mean to use volition in the simple sense that someone (say, a creditor) may choose to act with respect to another (for example, by choosing to extend credit to a debtor). Webster's New Collegiate Dictionary would support this reading, as it defines volition to mean "an act of making a choice or decision ... the power of choosing or determining." WEBSTER'S NEW COLLEGIATE DICTIONARY 1302 (1981).

Similarly, I recognize that "cognition" may refer to human faculties for processing information, see Herbert A. Simon \& William G. Chase, The Mind's Eye in Chess, in MODELS OF THOUGHT 404, 413-15 (Herbert A. Simon ed., 1979) (discussing cognition as the capacity to process information), to a feature of emotion, see, e.g., Cass R. Sunstein, Cognition and Cost-Benefit Analysis, 29 J. LEGAL STUD. 1059, 1070 (2000) ("There is no sharp distinction between cognition and emotion.") (citations omitted), or to our moral imagination, among other things, see, e.g., MARK JOHNSON, MORAL IMAGINATION (1993). As with volition, I use the term cognition simply to describe the access that a person (say, a creditor) may have to information about another person (say, a debtor to whom the creditor extends credit). Here, too, Webster's might be helpful, defining cognition as "the act or process of knowing[,] including both awareness and judgment." WEBSTER'S, supra, at 215.
} 
The current crisis in corporate governance ${ }^{5}$ will doubtless lead many to examine more carefully the rules that govern the relationship between corporate insiders (directors and officers) and shareholders. ${ }^{6}$ Yet it is apparent that cases like Credit Lyonnais create even greater problems for corporate stewards, since they may vastly expand potential liability and yet create no correlative protections. By tying duty to its underlying normative base, this Article offers a solution to these problems by rationalizing and limiting duties to creditors. Directors' duties to creditors should, in short, be determined not by the nature or priority of the claim, but by the circumstances and relationships that give rise to it.

This Article proceeds in four major parts. Part I considers the relationship between debt and duty, and focuses on the two models that govern discussions about directorial duties to creditors: the event/condition paradigm, and the efficiency paradigm. Both approaches to the problem share the assumption that priority in right of payment should govern directors' duties. Part II evaluates problems with priority that demonstrate its limitations as a basis for determining whether creditors should benefit from directorial duties. Part III proposes that imbalances in volition, cognition, and exit should supplement priority in determining duties to creditors of distressed corporations, and offers examples of creditors that should and should not benefit from such duties. Part IV considers some of the implications of this proposal.

\section{DEBT AND DUTY}

Debt and duty are generally viewed as mutually exclusive categories of obligation. ' Debt is principally the obligation to pay money, and arises

5. Between January 2001 and December 2002, seven of the ten largest business bankruptcy cases in modern U.S. history were commenced. See The Largest Bankruptcies 1980-Present, at http://www.bankruptcydata.com/Research/15_Largest.htm (Dec. 27, 2002). These included the bankruptcies of Worldcom (the largest, with more than $\$ 100$ billion in claimed pre-bankruptcy assets) and Enron (the second largest, with more than $\$ 60$ billion in claimed pre-bankruptcy assets). Id.

6. The Enron case has already spawned a cottage industry among legal academics. See, e.g., Douglas G. Baird \& Robert K. Rasmussen, Four (or Five) Easy Lessons from Enron, 55 VAND. L. REV. 1787 (2002); William W. Bratton, Enron and the Dark Side of Shareholder Value, 76 TUL. L. REV. 1275 (2002); Mark Klock, Two Possible Answers to the Enron Experience: Will It Be Regulation of Fortune Tellers or Rebirth of Secondary Liability? 28 J. CORP. L. 69 (2002); Symposium, Enron and Its Aftermath: Rebuilding Corporate Boards and Refocusing Shareholders for the Post-Enron Era, 76 ST. JOHN'S L. REV. 787 (2002); Symposium, Lessons from Enron: A Symposium on Corporate Governance, 54 MERCER L. REV. 663 (2003).

7. A typical expression is thus: "A debtor-creditor relationship is qualitatively different from the traditional examples of fiduciary relationships." Steven L. Schwarcz, Rethinking a Corporation's Obligations to Creditors, 17 CARDOZO L. REV. 647, 655, n.38 (1996); see also Frank Partnoy, Adding Derivatives to the Corporate Law Mix, 34 GA. L. REV. 599, 611 (2000) ("United 
largely by contract or operation of law. It is a fairly simple obligation, and the failure to satisfy the obligation usually results in a monetary judgment against the debtor.

Duty, by contrast, is a profoundly more complex class of obligations. Duty may describe, among other things, the obligations owed by agent to principal, ${ }^{8}$ attorney to client, ${ }^{9}$ partner to partner, ${ }^{10}$ trustee to beneficiary, and corporate director to corporation and shareholder." If duty should exist at all-a contested claim ${ }^{12}$ - it does so largely by virtue of common law edicts about extracontractual relations. ${ }^{13}$ A suit alleging a breach of duty

States corporate law generally assigns control to equity; debt then bargains for specific contractual provisions to protect its interests. Similarly, under normal circumstances, managers owe duties to shareholders but not to bondholders.").

8. See Union Miniere, S.A. v. Parday Corp., 521 N.E.2d 700, 703 (Ind. Ct. App. 1988).

9. See FDIC v. Mmahat, 907 F.2d 546 (5th Cir. 1990); Croce v. Kurnit, 565 F. Supp. 884, 890 (S.D.N.Y. 1982); David Welch Co. v. Erskine \& Tulley, 250 Cal. Rptr. 339, 341 (Ct. App. 1988) ("The relation between attorney and client is a fiduciary relation of the very highest character, and binds the attorney to most conscientious fidelity-uberrima fides.") (quoting Cox v. Delmas, 33 P. 836, 839 (Cal. 1893)); STEPHEN GILlERS \& NORMAN DORSEN, REGULATION OF LAWYERS: PROBLEMS OF LAW AND ETHICS 409-10 (2d ed. 1989).

10. See Latta v. Kilbourn, 150 U.S. 524, 543 (1893); cf. UNIF. P'SHIP ACT § 21, 6 U.L.A. 194 (2001) (entitled "Partner Accountable as a Fiduciary").

11. See Gratz v. Claughton, 187 F.2d 46, 49 (2d Cir. 1954) (Hand, J.); Paramount Communications, Inc. v. QVC Network, 637 A.2d 34, 43 (Del. 1994); Guth v. Loft, Inc., 5 A.2d 503, 510 (Del. 1939); AmERICAN LAW INSTITUTE, PrinCIPLES OF CORPORATE GOVERNANCE: ANALYSIS AND RECOMMENDATIONS, PART V, INTRODUCTORY NOTE (Tentative Draft No. 5, 1986); Robert W. SOUTHGate \& DONALD W. Glazer, MassachusetTS Corporation LAW \& Practice 242-72.1 (2000); cf. Revised MOdel Bus. CORP. ACT $\$ 8.30$ (a) cmt. (1984) ('Section 8.30 does not use the term 'fiduciary' in the standard for directors' conduct, because that term could be confused with the unique attributes and obligations of a fiduciary imposed by the law of trusts, some of which are not appropriate for directors of a corporation."). See generally Harold Marsh Jr., Are Directors Trustees?: Conflict of Interest and Corporate Morality, 22 BUS. LAW. 35 (1966). Professor FitzGibbon has done an admirable job of preparing a précis of the various types of duty relationships in Scott FitzGibbon, Fiduciary Relationships Are Not Contracts, 82 MARQ. L. REV. 303, 306-07 (1999).

12. As discussed in Part I.A., a number of contractually-oriented writers associated with the law and economics school have argued that duty is an illusory class of obligation; everything, according to contractarians, may be explained as a function of express or implied contract.

13. Of course, fiduciary or similar duties may be said to arise under certain statutes. For example, section 3(21)(A) of the Employee Retirement Income Security Act of 1974 (ERISA) 29 U.S.C. $\$ 1002(21)$ (A) (1994), provides that, except for certain investment companies, a person is a plan fiduciary "to the extent" he (i) "exercises ... discretionary authority or ... control" over plan management or "any authority or control" over "management or disposition of [plan] assets," (ii) "renders investment advice [regarding plan assets] for a fee or other compensation... or has ... authority or responsibility to do so, or (iii) ... has any discretionary authority or. . . responsibility" in plan administration. See NLRB v. Amax Coal Co., 453 U.S. 322, 329-30 (1981) (explaining that Congress intended Taft-Hartley plan trustees to be fiduciaries and not representatives of bargaining parties); Donovan v. Mercer, 747 F.2d 304, 309 (5th Cir. 1984) (citing Department of Labor regulation); Narda, Inc. v. Rhode Island Hosp. Trust Nat'l Bank, 744 F. Supp. 685, 693 (D. Md. 1990); Freund v. Marshall \& Ilsley Bank, 485 F. Supp. 629, 635 (W.D. Wis. 1979). Under section 402(a), a "named fiduciary" must be appointed with overall fiduciary responsibility 
may result in either a monetary judgment or any of a large number of equitable remedies, including an injunction for specific performance.

\section{A. Nature and Theory of Duty}

In the corporate context, directors are generally said to owe duties of care and loyalty to the corporation. Although it often has little practical force, the duty of care requires directors to be reasonably well informed about the risks and rewards of any given course of corporate action. ${ }^{14}$ The greater the significance of the action, the better informed the directors should be. ${ }^{15}$

The duty of care may be at its strongest when corporation control is in play. Such famous cases as Van Gorkom ${ }^{16}$ and Revlon ${ }^{17}$ suggest that, in contests for corporation control, the duty of care requires directors to maximize firm value for shareholders. Otherwise, the duty of care is considered weak for a variety of reasons. Among other things, directors are insulated from

for the plan. See 29 U.S.C. \& 1102(a); Pension Benefit Guar. v. Pritchard (In re ESCO Mfg. Co.), 50 F.3d 315, 316 (5th Cir. 1995) (discussing the appointment requirement); Confer v. Custom Eng'g Co., 952 F.2d 34, 36 (3d Cir. 1991) (same); Yeseta v. Baima, 837 F.2d 380, 384 (9th Cir. 1988); Birmingham v. SoGen-Swiss Int'l Corp. Ret. Plan, 718 F.2d 515, 521-22 (2d Cir. 1983); Arakelian v. National Western Life Ins. Co., 680 F. Supp. 400,404 (D.D.C. 1987).

14. "The duty of care includes a duty [on the part of directors] to inform themselves, prior to making a business decision, of all material information reasonably available to them." ERnest L. Folk, III et al. Folk on the Delaware General Corporation law: A COMMENTARY AND ANALYSIS $§ 141.2 .1 .1$ (3d ed. 1992). According to the Business Law Section of the American Bar Association, at least under the Model Business Corporation Act, "[a] director's duty of care relates to the director's responsibility to exercise appropriate diligence in making decisions and taking other action, as well as in overseeing management of the corporation." COMMITTEE ON CORPORATE LAWS, AMERICAN BAR ASSOCIATION, CORPORATE DIRECTOR'S GUIDEBOOK (3d ed. 2001), reprinted in 56 BUS. LAW. 1571, 1582 (2001). Directors discharge these duties if they (i) "attend and participate ... in board and committee meetings," (ii) have and review "sufficient and accurate information to keep them[selves] properly informed about the business and affairs of the corporation," (iii) "rely ... on reports, opinions, information, and statements" presented by professionals retained by the corporation or the corporation's officers, employees or other board members "whom the director[s] reasonably believe[ ] to be reliable and competent in the matters presented," and, (iv) "make inquiry into potential problems or issues when alerted by circumstances or events which indicate that board attention is appropriate." Id. at 1582-83. Grounds for further inquiry may include "red flags' indicating that the corporation is or may be experiencing significant problems in a particular area of business." Id. at 1583.

15. See Mills Acquisition Co. v. Macmillan, Inc., 559 A.2d 1261, 1281 (Del. 1989) ("While a board of directors may rely in good faith upon 'information, opinions, reports or statements presented' by corporate officers, employees, and experts 'selected with reasonable care, DEL. CODE ANN. tit. $8 \$ 141$ (e) (1991), it may not avoid its active and direct duty of oversight in a matter as significant as the sale of corporate control.").

16. Smith v. Van Gorkom, 488 A.2d 858 (Del. 1985).

17. Revlon, Inc. v. MacAndrews \& Forbes Holdings, Inc., 506 A.2d 173 (Del. 1986). 
breach of duty of care claims by the business judgment rule, ${ }^{18}$ exculpatory charter provisions, ${ }^{19}$ and/or fairness or similar opinions. ${ }^{20}$

Unlike the duty of care, the duty of loyalty has had a fairly robust career. The duty of loyalty requires a corporate agent to subordinate his interests to those of the corporation. ${ }^{21}$ Directors or other corporate agents may violate the duty of loyalty by using corporate assets for personal gain, ${ }^{22}$ misappropriating corporate opportunities, ${ }^{23}$ paying excessive compensation, ${ }^{24}$

18. As Judge Ralph Winter observed:

While it is often stated that corporate directors and officers will be liable for negligence in carrying out their corporate duties, all seem agreed that such a statement is misleading.... [L]iability is rarely imposed upon corporate directors or officers simply for bad judgment and this reluctance to impose liability . . . has been doctrinally labelled the business judgment rule.

Joy v. North, 692 F.2d 880, 885 (2d Cir. 1982) (citations omitted).

19. See, e.g., DEL. CODE ANN. tit. 8, \$102(b)(7) (1991). Section 102(b)(7) of the Delaware General Corporation Law authorizes a charter provision limiting or eliminating the liability of directors except for: "breach of the director's duty of loyalty; acts or omissions not in good faith or which involve intentional misconduct or a knowing violation of law; [liability for unlawful dividends]; or [the receipt of] an improper personal benefit." Id.

20. "A fairness opinion, typically presented in the form of a letter to the board, contains the issuer's opinion regarding the fairness or adequacy to the corporation or its shareholders of the financial terms of a proposed transaction." Helen M. Bowers, Faimess Opinions and the Business Judgment Rule: An Empirical Investigation of Target Firms' Use of Faimess Opinions, 96 Nw. U. L. REV. 567, 569-70 (2002) (footnote omitted). Although their use predates Van Gorkom, fairness opinions are often associated with that case, since it "created the obligation that when evaluating a takeover proposal, the corporate boards of target firms must inform themselves of all reasonably available and relevant information to the decision." Id. at 567. Fairness opinions are thought by some to be one such source of information. Bill Shaw \& Edward J. Gac, Faimess Opinions in Leveraged Buy Outs: Should Investment Bankers Be Directly Liable to Shareholders?, 23 SEC. REG. L.J. 293, 293 (1995) ("Over the last decade, the fairness opinion has become a necessary and integral aspect of every major corporate control transaction. Directors feel they must seek the advice and blessing of investment banks before engaging in an action that requires them to enter the thicket of conflicting interests.").

21. Pepper v. Litton, 308 U.S. 295, 306-07 (1939); Geddes v. Anaconda Copper Mining Co., 254 U.S. 590, 599 (1921); Edelman v. Fruehauf Corp., 798 F.2d 882, 886 (6th Cir. 1986); Norlin Corp. v. Rooney, Pace, Inc., 744 F.2d 255, 264 (2d Cir. 1984); Cede \& Co. v. Technicolor, Inc., 634 A.2d 345, 361-62 (Del. 1993); Mills Acquisition Co. v. MacMillan, Inc., 559 A.2d 1261, 1264, 1279-80 (Del. 1988); Lewis v. Fuqua, 502 A.2d 962, 966-67 (Del. Ch. 1985); Pogostin v. Rice, 480 A.2d 619, 623-24 (Del. 1984); Aronson v. Lewis, 473 A.2d 805, 812 (Del. 1984); 3 William MEAdE FletCHER, ET AL., FletCHER CyClopedia OF THE LAW OF PRIVATE CORPORATIONS $\$ 837.60$ (perm. ed. rev. vol. 2002); FOLK, supra note 14, at $\$ 141.2 .1 .1$.

22. See e.g., Diamond v. Oreamuno, 248 N.E.2d 910, 913-15, (N.Y. 1969) (officers held liable to the corporation for selling stock after corporate earnings dropped, but before that information was published); AMERICAN LAW INSTITUTE, PRINCIPLES OF CORPORATE GOVERNANCE: ANALYSIS AND RECOMMENDATIONS $\$ 5.05$ (1994) [hereinafter ALI PRINCIPLES].

23. See, e.g., Miller v. Miller, 222 N.W.2d 71 (Minn. 1974).

24. See, e.g., Rogers v. Hill, 289 U.S. 582, 591-92 (1933). 
wasting corporate assets, ${ }^{25}$ competing with the corporation, ${ }^{26}$ selling control of the corporation, ${ }^{27}$ or abusing a corporate subsidiary, ${ }^{28}$ among other things.

Delaware corporate law protects directors from liability for claims of a breach of the duty of loyalty in two general ways. First, section 144 of the Delaware General Corporation Law provides that the informed support of "independent" directors for a transaction will "cleanse" it of any taint resulting from the fact that certain directors might have had an interest in the transaction, thus placing their loyalty in question. ${ }^{29}$ Even without the cleansing vote of disinterested directors, a self-aggrandizing transaction may be permissible if directors prove its "entire fairness" to the corporation. ${ }^{30}$

As a matter of legal theory, there have been two general approaches to the problem of duty in the corporate context. On the one hand, there are the economically-oriented writers, sometimes called contractarians, who tend to argue that fiduciary duty in the corporate context is illusory at best, and

25. See, e.g., Michelson v. Duncan, 407 A.2d 211, 217 (Del. 1979); ALI PRINCIPLES, supra note $22, \$ 5.03$.

26. See, e.g., ALI PRINCIPLES, supra note 22, § 5.06.

27. See, e.g., Perlman v. Feldmann, 219 F.2d 173, 175-76 (2d Cir. 1955); Jones v. H.F. Ahmanson \& Co., 460 P.2d 464 (Cal. 1969).

28. See, e.g., Sinclair Oil v. Levien, 280 A.2d 717, 719-23 (Del. 1971).

29. This section provides as follows:

(a) No contract or transaction between a corporation and 1 or more of its directors or officers, or between a corporation and any other corporation, partnership, association, or other organization in which 1 or more of its directors or officers, are directors or officers, or have a financial interest, shall be void or voidable solely for this reason, or solely because the director or officer is present at or participates in the meeting of the board or committee which authorizes the contract or transaction, or solely because his or their votes are counted for such purpose, if:

(1) The material facts as to his relationship or interest and as to the contract or transaction are disclosed or are known to the board of directors or the committee, and the board or committee in good faith authorizes the contract or transaction by the affirmative votes of a majority of the disinterested directors, even though the disinterested directors be less than a quorum; or

(2) The material facts as to his relationship or interest and as to the contract or transaction are disclosed or are known to the shareholders entitled to vote thereon, and the contract or transaction is specifically approved in good faith by vote of the shareholders; or

(3) The contract or transaction is fair as to the corporation as of the time it is authorized, approved or ratified, by the board of directors, a committee or the shareholders.

DEL. CODE ANN. tit. 8, § 144 (1996).

30. Del. CODE ANN. tit. 8, § 144 (1996); see also Geddes v. Anaconda Copper Mining Co., 254 U.S. 590, 599 (1920); Edelman v. Fruehauf Corp., 798 F.2d 882, 886 (6th Cir. 1986); Cede \& Co. v. Technicolor, Inc., 634 A.2d 345, 361-62 (Del. 1993); Mills Acquisition Co. v. Macmillan, Inc., 559 A.2d 1261, 1264, 1279-80 (Del. 1989); Aronson v. Lewis, 473 A.2d 805, 812 (Del. 1984); Pogostin v. Rice, 480 A.2d 619, 623-24 (Del. 1984); Lewis v. Fuqua, 502 A.2d 962, 970-71 (Del. Ch. 1985). 
inefficient at worst. ${ }^{31}$ Rather than speaking in terms of duties, courts should acknowledge that, in the words of Frank Easterbrook and Daniel Fischel, fiduciary duty is nothing more than a contract that happens to be "characterized by unusually high costs of specification and monitoring.".32

The contractarian position emanates from the view that a corporation is nothing more than a nexus of contracts. That is, the corporation is the construct through which the various participants in the enterprise organize their relations, all of which can be said to be more or less contractual. ${ }^{33}$ Contract is understood in economic, ${ }^{34}$ rather than legal terms, and refers generally to any relationship characterized by "asymmetric information, bilateral monopoly, and opportunism." ${ }^{35}$ Duty, on this view, is simply one more right for or against which parties can contract.

31. See, e.g., Stephen M. Bainbridge, Community and Statism: A Conservative Contractarian Critique of Progressive Corporate Law Scholarship, 82 CORNELL L. REV. 856, 858-73 (1997) [hereinafter Bainbridge, Community]; Henry N. Butler \& Larry E. Ribstein, Opting out of Fiduciary Duties: A Response to the Anti-Contractarians, 65 WASH. L. REV. 1, 71-72 (1990); Frank H. Easterbrook \& Daniel R. Fischel, Contract and Fiduciary Duty, 36 J.L. \& ECON. 425, 426-27 (1993) [hereinafter Easterbrook \& Fischel, Contract and Duty]; Frank H. Easterbrook \& Daniel R. Fischel, The Corporate Contract, 89 ColuM. L. REv. 1416 (1989) [hereinafter Easterbrook \& Fischel, Corporate Contract); Frank H. Easterbrook \& Daniel R. Fischel, Voting in Corporate Law, 26 J.L. \& ECON. 395 (1983) [hereinafter Easterbrook \& Fischel, Voting]; William A. Klein, The Modern Business Organization: Bargaining Under Constraints, 91 YALE. L.J. 1521, 1526 (1982); Jonathan R. Macey \& Geoffrey P. Miller, Good Finance, Bad Economics: An Analysis of the Fraudon-the-Market Theory, 42 STAN. L. REV. 1059, 1068-69 (1990); see also Lucian Arye Bebchuk, The Debate on Contractual Freedom in Corporate Law, 89 COLUM. L. REV. 1395, 1395-96, 1426-34 (1989) (describing the contractarian position).

32. Easterbrook \& Fischel, Contract and Duty, supra note 31, at 427

33. See Jeffrey N. Gordon, The Mandatory Structure of Corporate Law, 89 COLUM. L. REV. 1549 (1989) (describing the nexus of contracts view: "the corporate entity is nothing more than a gathering point for a series of contracts, express and implied, among assorted actors: shareholders, bondholders, managers, employees, suppliers and customers, for example.")

34. "The contractual approach to the firm was developed by economists." Thomas A. Smith, The Efficient Norm for Corporate Law: A Neotraditional Interpretation of Fiduciary Duty, 98 MiCH. L. ReV. 214, 216, n.11 (1999). The leading exposition by an economist is R.H. Coase, The Nature of the Firm, 4 ECONOMICA 386, 390-92 (1937). Legal adaptations appear in, e.g., RICHARD A. POSNER, ECONOMIC ANALYSIS OF LAW 292-93 (2d ed. 1977); Bainbridge, Community, supra note 31, at 858-73; Butler \& Ribstein, supra note 31; Henry N. Butler \& Larry E. Ribstein, State Anti-Takeover Statutes and the Contract Clause, 57 U. CIN. L. REV. 611, 615-17 (1988); Steven N.S. Cheung, The Contractual Nature of the Firm, 26 J.L. \& ECON. 1 (1983); Eugene F. Fama \& Michael C. Jensen, Separation of Owmership and Control, 26 J.L. \& ECON. 301 (1983); Easterbrook \& Fischel, Corporate Contract, supra note 31, at 1429 ("Perhaps the corporate contract, like the social contract, is no more than a rhetorical device."); Easterbrook \& Fischel, Voting, supra note 31, at 401; Klein, supra note 31, at 1521; Macey \& Miller, supra note 31, at 1068 ("[Clourts should treat an allegation of a breach of fiduciary duty as they would treat any other alleged breach of contract."); Oliver E. Williamson, Corporate Govemance, 93 YALE L.J. 1197,1200 (1984) [hereinafter Williamson, Corporate Govemance]; Oliver E. Williamson, The Modern Corporation: Origins, Evolution, Attributes, 19 J. ECON. LIT. 1537 (1981).

35. Stephen M. Bainbridge, The Board of Directors as Nexus of Contracts, 88 IOWA L. REV. 1, 10 (2002) [hereinafter Bainbridge, Board as Nexus]. In this article Stephen Bainbridge argues 
The contractarian approach stands in contrast to anticontractarian or progressive theories of duty. ${ }^{36}$ Anticontractarians generally have little trouble imposing extracontractual duties on corporate directors, at least to the extent that these duties run to or for the benefit of shareholders. As the name suggests, anticontractarian scholars fundamentally disagree with contractarians about the negotiability of duty. ${ }^{37}$ To anticontractarians, who include Victor Brudney, Melvin Eisenberg and Tamar Frankel, contract cannot and should not fully and exclusively explain the multitude of relationships in corporate life. ${ }^{38}$ Reducing duty to contract "misses the heart of that special bond." ${ }^{39}$ Moreover, a contractarian world would be a political and social nightmare, a devolved war of all against all. "The rhetoric of contract," Victor Brudney explains, "proceeds on doubtful assumptions about the circumstances of the parties, imports inappropriate normative consequences to govern the relationships thus assumed, and serves the ideological function of legitimating substantially unaccountable managerial discretion to determine corporate activities and to serve itself at the expense of investors."

\section{B. Duties to Creditors}

When a firm is solvent, there is little reason to think that corporate directors should owe fiduciary duties to creditors. ${ }^{41}$ These duties run solely

that corporate directors-rather than the corporation as such-are the "nexus" through which corporate participants contract.

36. This sentence implies a relationship between contractarians and anticontractarians. Bainbridge has suggested that the two schools may more accurately be characterized as "ships [passing] in the night." See Bainbridge, Community, supra note 31, at 860.

37. Lucian Arye Bebchuk, Limiting Contractual Freedom in Corporate Law: The Desirable Constraints on Charter Amendments, 102 HARV. L. REV. 1820 (1989); Victor Brudney, Corporate Governance, Agency Costs, and the Rhetoric of Contract, 85 COLUM. L. REV. 1403 (1985) [hereinafter Brudney, Corporate Govemance]; John C. Coffee, Jr., The Mandatory/Enabling Balance in Corporate Law: An Essay on the Judicial Role, 89 COLUM. L. REV. 1618 (1989); Gordon, supra note 33 , at 1551 .

38. See Brudney, Corporate Governance, supra note 37, at 1403-10; Melvin Aron Eisenberg, The Structure of Corporation Law, 89 COLUM. L. REV. 1461 (1989); Tamar Frankel, Fiduciary Duties as Default Rules, 74 OR. L. REv. 1209 (1995) [hereinafter Frankel, Fiduciary Duties]; Tamar Frankel, Fiduciary Law, 71 CAL. L. ReV. 795 (1983).

39. Margaret M. Blair \& Lynn A. Stout, Trust, Trustworthiness, and the Behavioral Foundations of Corporate Law, 149 U. PA. L. REV. 1735, 1782 (2001) [hereinafter Blair \& Stout, Trust].

40. See Brudney, Corporate Governance, supra note 37, at 1404.

41. See, e.g., Lorenz v. CSX Corp., 1 F.3d 1406, 1417 (3d Cir. 1993) ("[A] corporation does not have a fiduciary relationship with its debt security holders, as with its shareholders. The relationship between a corporation and its debentureholders is contractual in nature."); Metropolitan Life Ins. Co. v. RJR Nabisco, Inc., 716 F.Supp. 1504, 1524-25 (S.D.N.Y. 1989). 
to or for the benefit of the corporation and its shareholders. Some have made the unpopular suggestion that directors of solvent firms should be considered fiduciaries of bondholders or employees; there appears to be little support for these positions, however. ${ }^{42}$

At the margins, however, debt and duty do cohabit awkwardly, and have done so for many years. For example, certain statutory ancestors of our current system of personal property secured finance-chiefly the Uniform Trust Receipts Act-expressly invoked the rhetoric (if not the fact) of duty. ${ }^{43}$ Under the current personal property secured finance regime-Article 9 of the Uniform Commercial Code ${ }^{44}$-a secured party may pursue, or "trace," proceeds of collateral on the theory that the debtor is a trustee of sorts for the secured party. ${ }^{45}$ In the truly odd case, the foreclosing secured creditor has been characterized as owing a fiduciary duty to the debtor. ${ }^{46}$

Contemporary bankruptcy law also blurs the distinction. Upon commencement of a bankruptcy case, a fiduciary of some sort (a debtor in possession or a trustee in bankruptcy) is appointed to reorganize or liquidate the debtor's assets and affairs. ${ }^{47}$ The Bankruptcy Code $^{48}$ defines the term "claim" broadly to include claims for an "equitable remedy for breach of performance, if [the] . . . breach gives rise to a right to payment." ${ }^{\text {"49 }}$ This may encompass claims for the breach of a fiduciary duty. Although some have argued that " $[\mathrm{a}]$ debtor-creditor relationship is qualitatively different from the traditional examples of fiduciary relationships, ${ }^{, 50}$ there is a long (if not

42. As to bondholders, see Albert H. Barkey, The Financial Articulation of a Fiduciary Duty to Bondholders with Fiduciary Duties to Stockholders of the Corporation, 20 CREIGHTON L. REV. 47 (1986); Victor Brudney, Contract and Fiduciary Duty in Corporate Law, 38 B.C. L. REV. 595 (1997) [hereinafter Brudney, Contract and Duty]; Michael E. DeBow \& Dwight R. Lee, Shareholders, Nonshareholders and Corporate Law: Communitarianism and Resource Allocation, 18 DEL. J. CORP. L. 393 (1993); David M.W. Harvey, Bondholders' Rights and the Case for a Fiduciary Duty, 65 ST. JOHN'S L. REV. 1023 (1991); Lawrence E. Mitchell, The Faimess Rights of Corporate Bondholders, 65 N.Y.U. L. REV. 1165 (1990). As to employees, see materials cited in footnote 256, infra.

43. See, e.g., UNIF. TRUST RECEIPTS ACT $\$ 9(2)$ (a), 9C U.L.A. 255 (1957).

44. See U.C.C. \& 9-101, et seq. (2001).

45. See Universal C.I.T. Credit Corp. v. Farmers Bank, 358 F.Supp. 317, 325-27 (E.D. Mo. 1973); see also Jonathan C. Lipson, Remote Control: Revised Article 9 and the Negotiability of Information, 63 OHIO ST. L. J. 1327, 1393-1403 (2002) (discussing the history and development of rules on proceeds).

46. See Solfanelli v. Corestates Bank, N.A., 203 F.3d 197, 200 (3d Cir. 2000) (stating that a secured party "acts as the debtor's fiduciary" in connection with a secured party's disposition of collateral).

47. See, e.g., 11 U.S.C $\$ \S 701,1107$ (2000) (providing that a trustee be appointed upon commencement of a Chapter 7 bankruptcy case and that a debtor in possession shall act as trustee upon commencement of a Chapter 11 bankruptcy case).

48. 11 U.S.C. $\$ \S 101-1330(2000)$.

49. 11 U.S.C. $\$ 101(5)$ (B) (2000).

50. Schwarcz, supra note 7 , at 655 n.38. 
fully understood) tradition of treating creditors of the distressed firm as benefiting from fiduciary duties of some sort.

Courts $^{51}$ and commentators ${ }^{52}$ routinely assume that once a firm is distressed, directors owe fiduciary duties to corporate creditors. Although there are comparatively few cases actually holding directors liable for breaching a duty to creditors, ${ }^{53}$ there is no shortage of language exhorting directors to recognize that they must act in the interests of firm creditors once the firm is in financial distress. ${ }^{54}$

What this means and why this should be so are not completely clear. Two distinct, but related, paradigms dominate explanations of this phenomenon. First, duties to creditors may be explained as a function either of the occurrence of a certain event (for example, liquidation) or of the development of a financial condition (for example, insolvency). The event/condition paradigm is at work in most judicial decisions on duties to creditors, and explains when, if ever, duties to creditors should arise. It does not, however, explain why duties should arise at all, or to whom they should run. Second, duty may be seen as a function of concerns about efficiency. The efficiency paradigm tends to explain who should benefit from duty, rather than when duty should arise. The efficiency paradigm has not, however, recognized the power imbalances among corporate stakeholders that are the subject of this Article.

51. See supra note 1.

52. See supra note 2 .

53. See e.g., Unsecured Creditors Comm. of Debtor STN Enters. v. Noyes (In re STN Enters.), 779 F.2d 901, 904 (2d Cir. 1985) (Vermont law); Clarkson Co. v. Shaheen, 660 F.2d 506, 512 (2d Cir. 1981) (New York law) (superseded by state statute); FDIC v. Sea Pines Co., 692 F.2d 973, 977 (4th Cir. 1982) (South Carolina law); Brown v. Presbyterian Ministers Fund, 484 F.2d 998, 1005 (3d Cir. 1973) (Pennsylvania law) (superseded by state statute); Automatic Canteen Co. of Am. v. Wharton, 358 F.2d 587, 590 (2d Cir. 1966) (Indiana law); Official Comm. of Unsecured Creditors of Toy King Distribus. v. Liberty Sav. Bank (In re Toy Distribs., Inc.), 256 B.R. 1 (Bankr. M.D. Fla. 2000); Brandt v. Hicks, Muse \& Co. (In re Healthco, Int'l, Inc.), 208 B.R. 288, 300 (Bankr. D. Mass. 1997); Comm. of the Creditors of Xonics Medical Sys., Inc. v. Haverty (In re Xonics, Inc.), 99 B.R. 870, 872 (Bankr. N.D. Ill. 1989); Beemer v. Crandon Enters. (In re Holly Hill Medical Ctr., Inc.), 53 B.R. 412, 413-14 (Bankr. M.D. Fla. 1985); Waldschmidt v. Gilly (In re IMI, Inc.), 17 B.R. 784, 786-87 (Bankr. E.D. Wis. 1982); Roberts v. Geremia (In re Roberts, Inc.), 15 B.R. 584, 586 (Bankr. D. R.I. 1981); A.R. Teeters \& Assoc. v. Eastman Kodak Co., 836 P.2d 1034, 1043 (Ariz. Ct. App. 1992); Francis v. United Jersey Bank, 432 A.2d 814, 824 (N.J. 1981); Geyer v. Ingersoll Publ'ns Co., 621 A.2d 784 (Del. Ch. 1992); Harff v. Kerkorian, 324 A.2d 215, 222 (Del. Ch. 1974), rev'd in part on other grounds, 347 A.2d 133 (Del. 1975); Rosebud Corp. v. Boggio, 561 P.2d 367, 372 (Colo. Ct. App. 1977); Snyder Elec. Co. v. Fleming, 305 N.W.2d 863, 869 (Minn. 1981); N.Y. Credit Men's Adjustment Bureau, Inc. v. Weiss, 110 N.E. 2d 397, 398 (N.Y. 1953); Hixson v. Pride of Texas Distrib. Co., Inc., 683 S.W.2d 173, 176 (Tex. Ct. App. 1985).

54. As discussed below, Credit Lyonnais may contain some of the most important hortatory language about duty, even though the directors there were absolved. 
Both paradigms share an important assumption: Duty should shadow priority in right of payment. That is, because directors owe fiduciary duties to the residual claimants of the firm, creditors will naturally become such claimants when the firm is insolvent. Thus, because unsecured creditors precede shareholders in order of priority (broadly understood), they become the beneficiaries of a duty. The balance of this part reviews these two paradigms and the role that priority plays within them.

\section{The Event/Condition Paradigm}

The blurring of debt and fiduciary duty is not new. As discussed in this part, directorial duties to creditors appear to be rooted in cases in which firms liquidated without making adequate provision for creditors (or worse, the directors caused the corporation to engage in a fraudulent conveyance). ${ }^{55}$ The key to these early cases, sometimes called the trust fund cases, is that the duty to creditors arose upon the occurrence of a discrete event, usually corporate liquidation. With the passage of time, and the growing complexity of the processes by which debtors resolve financial distress, liquidation was no longer a certain, or particularly useful, trigger for duty. Thus, more recent cases hold that duties to creditors arise upon the development of a condition-insolvency or some other form of distress.

\section{a. The Trust Fund Cases}

An early and oft-cited example of the blurring of debt and duty appears in the nineteenth century decision of Wood v. Dummer. ${ }^{56}$ Here, Justice Story announced the trust fund doctrine, holding that directors of a liquidating bank held corporate assets in "trust" for creditors of the bank. Justice Story reasoned that "stockholders have no right to any thing but the residuum of the capital stock, after payment of all the debts of the bank. The funds in their hands, therefore, have an equity attached to them, in favour of the creditors, which it is against conscience to resist." ${ }^{57}$ This equity was in the nature of a trust. The corporation's "capital stock is a trust fund for creditors,

55. See Wood v. Dummer, 30 F. Cas. 435 (C.C.D. Me. 1824) (No. 17,944); Am. Nat'l Bank of Austin v. Mortgageamerica Corp. (In re Mortgageamerica Corp.), 714 F.2d 1266 (5th Cir. 1983); Ford Motor Credit Co. v. Weaver, 680 F.2d 451, 461 (6th Cir. 1982); Johnson v. Clark (In re Johnson), 518 F.2d 246 (10th Cir. 1975); Asmussen v. Quaker City Corp., 156 A. 180 (Del. Ch. 1931).

56. 30 F. Cas. 435.

57. Id. at 439-40. 
and the stockholders, upon the division, take it subject to all equities attached to it." ${ }^{58}$

Wood is notable for at least two reasons. First, it established that duties arose upon the occurrence of an event-liquidation of the debtor. ${ }^{59}$ The duties appear not to have arisen at some point in time prior to liquidation, such as financial distress. Second, it linked duty to "residual rights" in the debtor's assets. Stockholders were entitled to the "residuum" only if debts to the plaintiff bondholders were paid in full. Unpaid creditors succeeded to the shareholders' residual rights, such as they were. An equity in favor of creditors attached to these assets (the residue) not because of any contract between the bank and its creditors, but instead because a contrary result would have been "against conscience."

Limited to its facts, Wood might simply have stood for the proposition that bank directors will be liable if they receive or distribute assets to shareholders before creditors are repaid in full. It might therefore have also reflected the special role that banks have long played in our system. Thus Wood might not have been taken as strong precedent on the duties of corporate directors in general. ${ }^{60}$

The case was not so limited. Wood's trust fund rule was briefly expanded in the mid-nineteenth century, in Curran v. Arkansas. ${ }^{61}$ There, it appears that the Supreme Court viewed the trust as arising at an even earlier time than liquidation: upon corporate formation. Forty years later, however, the Court pared the rule back considerably. In Hollins थ. Brierfield Coal $\mathcal{E}$ Iron

58. Id. at 437. Wood was not the first case to so hold. Justice Story cited a number of prior English and U.S. decisions to similar effect. See id. at $437 \&$ n.2 (citing Hill v. Simpson, 7 Ves. 152; Moses v. Murgatroyd, 1 Johns. Ch. 119 (1814); Dexter v. Stewart, 7 Johns. Ch. 52 (1823); Shepherd v. McEvers, 4 Johns. Ch. 136 (1819); Long v. Majestre, 1 Johns. Ch. 305 (1814); Riddle v. Mandeville, 9 U.S. (5 Cranch) 322 (1809); Russell v. Clark's Ex'rs, 11 U.S. (7 Cranch) 69 (1812)).

59. See Barnett, supra note 2, at 446; Beveridge, supra note 2, at 598-600.

60. Although Wood is routinely cited in support of the proposition that directors of a liquidating corporation owe fiduciary duties to creditors, see, e.g., Reif v. Equitable Life Assur. Soc'y, 197 N.E. 278, 280 (N.Y. 1935) (crediting Justice Story as the source of the trust fund doctrine), the case itself may have been somewhat aberrant. As Professor Stilson observes, the case may have turned on the nature of the debtor (a bank) and unusually bad lawyering for the plaintiffs. See Stilson, supra note 2, at 81 (suggesting Wood "resulted from ... dissolution of a bank-a special form of public corporation-and the failure of plaintiffs counsel to properly plead for relief"). Whether it should matter that the debtor was a bank is an interesting question. The plaintiffs in Wood were noteholders, not depositors. Banks are often viewed as being subject to special burdens vis-à-vis depositors, who usually have very little capacity to police bank activities. See Eric J. Gouvin, Of Hungry Wolves and Horizontal Conflicts: Rethinking the Justifications for Bank Holding Company Liability, 1999 ILL. L. REV. 949, 959-62 (discussing the "special" nature of banks).

61. 56 U.S. (15 How.) 304 (1853). 
Co., ${ }^{62}$ the Court held that liquidation-not corporate formation-would trigger an equitable duty to creditors. ${ }^{63}$ Nevertheless, as with Wood and Curran, duties to creditors arose upon the occurrence of an event, not the development of a condition.

More recent decisions go other ways, recognizing the impression of a trust upon the condition of insolvency, rather than the occurrence of a particular event. ${ }^{64}$ In New York Credit Men's Adjustment Bureau Inc. v. Weiss, ${ }^{65}$ for example, a trustee in bankruptcy sued two directors of a New York corporation for failing to obtain maximum value in selling the corporation's assets. $^{66}$ The action was based upon a New York statute ${ }^{67}$ which created a cause of action against directors for neglect or failure to perform their duties $^{68}$ Having attempted to cut costs and otherwise salvage the business, the directors determined that the business was not viable, and that they would have to liquidate it, which they did at a public auction. ${ }^{69}$ Although the assets had cost the debtor corporation approximately $\$ 60,000$, and had a book value in excess of $\$ 70,000$, the auction netted only $\$ 20,000$, which was paid to the bankruptcy trustee. ${ }^{70}$

Despite the absence of fraud or self-dealing by the directors, the New York Court of Appeals held that the bankruptcy trustee's case against the directors should not be dismissed." The court noted that "[i]f the corporation was insolvent at that time [of the alleged breach of duty,] it is clear that

62. 150 U.S. $371(1893)$.

63. Id. at 383 ("Whatever of trust there is arises from the peculiar and diverse equitable rights of the stockholders as against the corporation in its property and their conditional liability to its creditors."). See also Stilson, supra note 2, at 85 (discussing Hollins).

64. See, e.g., People v. Metro. Sur. Co., 98 N.E. 412 (N.Y. 1912); Heaney v. Riddle, 23 A.2d 456 (Pa. 1942); N.Y. Credit Men's Adjustment Bureau, Inc. v. Weiss, 110 N.E.2d 397 (N.Y. 1953); Clarkson Co. v. Shaheen, 660 F.2d 506, 512 (2d Cir. 1981) (New York law) (superseded by state statute); FDIC v. Sea Pines Co., 692 F.2d 973, 977 (4th Cir. 1982) (South Carolina law).

65. 110 N.E.2d 397 (N.Y. 1953).

66. Id. at 397 .

67. Id. 397-98. The plaintiff relied on section 60 of the New York General Corporation Law. Id. Section 60 states in pertinent part:

An action may be brought against one or more of the directors or officers of a corporation to procure judgment for the following relief or any part thereof:

$\cdots$

To compel them to pay to the corporation, or to its creditors, any money and the value of any property, which they have acquired to themselves, or transferred to others, or lost, or wasted, by or through any neglect of or failure to perform or other violation of their duties.

N.Y. BUS. CORP. LAW $\S 60$ (Consol. (1943)), re-enacted and modified in N.Y. BUS. CORP. LAW $\S 720$ (Consol. $1986 \&$ Supp. 1993).

68. Weiss, 110 N.E.2d at 397.

69. Id. at 398.

70. Id. at 399 .

71. See id. at 400 . 
[the] defendants, as officers and directors thereof, were to be considered as though trustees of the [corporation's] property for the corporate creditorbeneficiaries." by a different ("non-negligent") disposition of the property, the directors could be held liable for the difference, regardless of their good faith or motive in the transaction. ${ }^{73}$

The trust fund cases have enjoyed little academic support. The chief criticism is that the trust fund remedy is usually redundant when combined with other existing creditors' remedies, such as claims of fraudulent conveyance or unlawful dividend distribution. ${ }^{74}$ Under the various fraudulent transfer acts, for example, a transfer is avoidable if made with actual intent to hinder, delay or defraud creditors, or, regardless of intent, if made for less than adequate consideration, while the corporation is insolvent. ${ }^{75}$ Similarly, most corporation statutes hold directors liable for dividends or other distributions of corporate property that are either made while the corporation is insolvent or that cause insolvency. ${ }^{76}$

72. Id. at 398 (emphasis added).

73. See id. The rule enunciated in Weiss would appear to apply even if the corporation was technically solvent, if insolvency was imminent. See id. Weiss also suggests that director selfdealing is not the only basis for imposing fiduciary-like liability on directors. However, at least some courts believe that directors of the distressed firm do not breach a duty to creditors unless the directors have personally benefited from a transaction. For example, the court in St. James Capital Corp. v. Pallet Recycling Assocs., 589 N.W.2d 511 (Minn. Ct. App. 1999), observed that holding directors liable to creditors under a general negligence duty of care would "seriously erode the limited liability ... granted by the corporate structure." Id. at 515. More recently, the United States District Court for the Eastern District of Virginia observed that "self-dealing is uniformly present in cases from other jurisdictions" on directorial duties to creditors. Bank of America v. Musselman, 222 F.Supp.2d 792, 799-800 (E.D. Va. 2002). Neither the St. James Capital nor Musselman courts acknowledged the Weiss decision, or the more recent decision in Brandt $v$. Hicks, Muse (In re Healthco International, Inc.), 208 B.R. 288, 300 (Bankr. D. Mass. 1997), where, as discussed below, directors were held liable to creditors for breaching the duty of care, among other things.

74. See, e.g., Stilson, supra note 2, at 87; Beveridge, Jr., supra note 2, at 593-95, 621 (1994) (citing Reif v. Equitable Life Assur. Soc'y, 197 N.E. 278, 280 (N.Y. 1935) for the observation that the trust fund doctrine is "often ... repudiated as a fiction unsound in principle and vexing in business practice").

75. Every state has enacted one of the uniform fraudulent transfer laws. See UNIF. FRAUDULENT CONVEYANCE ACT, 7A U.L.A. 2 (1918); UNIF. FRAUDULENT TRANSFER ACT, 7A U.L.A. 266 (1984), or a predecessor statute with similar effect. See, e.g., VA. CODE ANN. \$ 55-81 (Michie 1995). The Bankruptcy Code also contains its own prohibition on fraudulent transfers. 11 U.S.C. $\$ 548(2000)$.

76. Section 174 of the Delaware General Corporation Law (DGCL), for example, provides that directors who willfully or negligently approve the payment of a dividend in excess of the levels permitted by section 170 of the DGCL are jointly and severally liable for a period of six years following payment of the unlawful dividend to (i) the corporation and (ii) if the corporation dissolves or becomes insolvent, its creditors. DEL. CODE ANN. tit. $8 \S 174$ (1991). Section 
The trust fund cases also vacillate on whether duties to creditors are triggered by a condition or the occurrence of an event. ${ }^{77}$ In some cases (Wood), the trust arose upon the occurrence of a discrete event-incorporation, liquidation, dissolution, or the commencement of insolvency proceedings. In others (Weiss), the trust arose upon the condition of insolvency. No particular theory is advanced in these decisions as to whether one approach is better than the other. It appears, however, that eventbased duties have the virtue of clarity, while condition-based duties provide more appropriate incentives to directors of the distressed corporation.

For example, if directors owe duties to creditors only in the (unlikely) event that the directors supervise liquidation, they will certainly know when duty arises, and to some extent even control the events that lead to the duty. Yet, the very fact that duty is triggered by causing certain events may deter directors from doing so. In other words, if directors know that liquidating the company will lead them to become fiduciaries for creditors (perhaps in addition to shareholders), they may understandably be expected to leave that task for someone else, such as a bankruptcy trustee. The bright line of the event-based duty would perhaps be an incentive to resign from the board rather than take appropriate corrective action.

Condition-based duties, by contrast, may lead to more appropriate directorial incentives, if only because duty will not necessarily act as a deterrent to what may be better decisionmaking. Since distress usually precedes liquidation, directors will be more likely to refrain from permitting that condition to develop. Condition-based duties are also somewhat more reflective of the practical economics of corporate and commercial life, since many distressed corporations do not liquidate, but rather reorganize. Linking directorial duties to the development of a condition certainly presents problems, however. Determining solvency in "real time" can be extremely difficult, as complex corporate assets and liabilities often escape concrete valuation. ${ }^{78}$ This absence of clarity may leave directors in the unenviable position of being unwitting fiduciaries for creditors.

2.02(b)(4) of the Model Business Corporation Act similarly penalizes directors for unlawful distributions. MODEL BUS. CORP. ACT ANN. § 2.02(b)(4) (2002).

77. The various approaches to timing are described in Shaffer supra note 2, at 546 . See generally J. Ronald Trost \& Roger G. Schwartz Fiduciary Duties of Directors in the Chapter 11 and Insolvency Contexts (with a Note on the Fiduciary Duties of Counsel for the Debtor-in-Possession), SE71 ALI-ABA 265 (2000).

78. See discussion in Part II.B.1, infra. 


\section{b. Credit Lyonnais-The "Vicinity" of Insolvency}

If decisions that link directorial duties to financial condition create uncertainty, they at least have the virtue of being rooted in some observable phenomena, such as distress. The landmark decision in Credit Lyonnais v. Pathe Communications, ${ }^{79}$ however, has no such virtue. There, the Delaware Chancery court announced that directors of a corporation "in the vicinity of insolvency," owed a duty to creditors "to exercise judgment in an informed, good faith effort to maximize the corporation's long-term wealth creating capacity. ${ }^{, 80}$ Because it is virtually impossible to know the location of the "vicinity of insolvency," Credit Lyonnais moved beyond the event/condition paradigm to an unmapped (perhaps unmappable) coordinate in the cartography of corporate finance. Not surprisingly, the decision was greeted with chagrin. ${ }^{81}$

Credit Lyonnais commenced as an action under section 225 of the Delaware General Corporation Law. ${ }^{82}$ The principal plaintiff, Credit Lyonnais Bank Nederland (CLBN), sued for a declaration of the lawful membership of the board of directors of MGM-Pathe Communications Company (MGM), a Delaware corporation. CLBN was a major lender both to MGM and to MGM's parent, Pathe Communications Corporation (PCC). The principal defendant was Giancarlo Parretti, who indirectly owned most of the stock of $\mathrm{MGM}^{83}$

The case arose out of the leveraged buyout (LBO) of MGM/UA Communications Company by Parretti's company, PCC, financed by CLBN ${ }^{84}$

79. Credit Lyonnais Bank Nederland, N.V. v. Pathe Communications Corp., No. 12150, 1991 Del. Ch. LEXIS 215, at*108-*09 (Del. Ch. Dec. 30, 1991).

80. See id.

81. John C. Coffee, Jr., Court Has a New Idea on Directors' Duty, NAT'L L. J., Mar. 2, 1992, at 18; Daniel J. Winnike, Credit Lyonnais: An Aberration or an Enhancement of Creditors' Rights in Delaware?, 6 INSIGHTS, JULY 1992, at 31; "Footnote of the Year" Has Lawyers Wondering About the Zone of Insolvency, 24 SEC. REG. \& L. REP. 388 (1992).

82. Credit Lyonnais, 1991 Del. Ch. LEXIS 215, at*1. Section 225 of the Delaware General Corporation Law provides in relevant part as follows:

Upon application of any stockholder or director ... the Court of Chancery may hear and

determine the validity of any election of any director ... and the right of any person to

hold such office, and, in case any such office is claimed by more than 1 person may determine the person entitled thereto .... .

DEL. CODE ANN. tit. 8 \& 225(a) (1991).

83. Credit Lyonnais, 1991 Del. Ch. LEXIS 215 , at *1-*2.

84. See id. at *7-*8. The court viewed the transaction as "typical" of the profligate nature of LBOs occurring at the end of the 1980s. "It was very highly leveraged ... and the price appears to have been high. In another respect, however, it was not typical [in that] it involved a private sale to a person not associated with MGM and resulted almost immediately in a liquidity crisis for the company." Id. at *8. 
After the LBO failed, MGM was forced into bankruptcy. ${ }^{85}$ As part of the strategy to have the bankruptcy case dismissed, CLBN and Parretti entered into a restructuring agreement which, among other things, placed an MGM designee, Alan Ladd, in charge of both day-to-day and important operational decisions. ${ }^{86}$ Although Parretti retained his controlling shares of MGM stock, he ceded most of his power as shareholder to CLBN and Ladd. ${ }^{87}$

Despite the restructuring agreement, it appears that Parretti persisted in attempting to control MGM ${ }^{88}$ Believing that Parretti was in breach of the restructuring agreement, CLBN exercised its right to take control of Parretti's stock, and voted the stock to remove Parretti and his designees from the board, and to replace them with those selected by CLBN. ${ }^{89}$ CLBN then sought judicial confirmation of its appointments and an injunction enforcing the restructuring agreement in the litigation that produced the Credit Lyonnais opinion. ${ }^{90}$

Parretti asserted a variety of counterclaims against CLBN, including two alleging that CLBN and Ladd had breached a duty to Parretti. ${ }^{91}$ First, Parretti argued that the bank and its team breached a duty by causing MGM to enter into severance agreements with certain members of the Ladd team. These severance agreements, which appeared to function like golden parachutes, would be triggered if Parretti regained control of MGM. Parretti asserted that these payments "represented a tax upon the shareholders' exercise of their right to elect the board and thus constituted a breach of duty." ${ }^{92}$

85. Id.

86. See id. at $* 32-* 33$.

87. See id. at $* 33$. Although Parretti retained the right to appoint three of the five members of MGM's board of directors, the board's power was significantly diminished because the restructuring agreement also created an executive committee, controlled by Ladd. See id. The executive committee was to have all of the powers and the duties permissible under the DGCL, and in most respects to act as the board of directors for MGM. Id. at *36 n.22.

88. See id. at *35 *70.

89. See id. at $* 70$.

90. See id.

91. See id. at *97-*98. Technically, Parretti claimed that the duty ran to PCC, which was the 98.5 percent shareholder of MGM. Since Parretti controlled PCC, I will refer to the owner of MGM's shares as Parretti.

92. Id. at *106. One could say that these contracts had the effect of entrenching management. Whether managerial entrenchment violates a duty is, itself, a subject of some study. Chancellor Allen (the author of the Credit Lyonnais opinion) observed in a recent article that, in addition to loyalty and care, a third class of duty may be characterized as the 'noentrenchment' duty: Even when directors "have no direct pecuniary interest in the transaction but have an 'entrenchment' interest, i.e., an interest in protecting their existing control of the corporation" they may, under Revlon, breach a duty of loyalty. See William T. Allen et al., Function Over Form: A Reassessment of Standards of Review in Delaware Corporation Law, 56 BUS. LAW. 1287, 1290 (2001). 
Chancellor William Allen summarily disposed of this claim. "It is," he observed "an oddity of these facts that the change in control that the contracts contemplated is one that would return control back to an existing controlling shareholder, but I don't see that circumstance as necessarily material." ${ }^{\prime 3}$ Thus, the severance agreements did not have "a substantial impact upon the exercise of the stockholders' franchise right (or in this case as affecting the stockholders['] ability otherwise to regain corporate control). ${ }^{.94}$

Second, Parretti claimed that the executive committee-with which the bank chose to share its contractual power to veto asset sales-"delayed and impeded the sale" of certain of MGM's assets, thereby delaying MGM's ability to repay CLBN, among other creditors. ${ }^{95}$ CLBN's team allegedly breached a duty to Parretti "by failing to facilitate sale transactions that Parretti sought in order to help him regain control.".96

Chancellor Allen also rejected this claim. He began his analysis here by noting, parenthetically, that the sale Parretti proposed would have been futile: "In fact," Chancellor Allen observed, "those proposed transactions were too little, too late ...."97 Thus, the bank team breached no duty to PCC or Parretti. ${ }^{98}$ Ignoring the question of whether the business judgment rule would or should have been available to protect decisions of the executive committee, Chancellor Allen wrote that "[u]nder any approach, I find that the Executive Committee decisions were valid and did not represent a breach of duty.... [There is] persuasive evidence that the Ladd management group acted prudently with respect to these transactions from the point of view of MGM. ${ }^{199}$

If Chancellor Allen had said no more than this, Credit Lyonnais would probably not have been a terribly important or controversial decision. However, Chancellor Allen then went on to announce what appears to have been a new, and ill-defined, set of duties owed by directors to or for the benefit of corporate creditors:

At least where a corporation is operating in the vicinity of insolvency, a board of directors is not merely the agent of the residue risk bearers, but owes its duty to the corporate enterprise. The Ladd management [team] was not disloyal in not immediately facilitating whatever asset sales were in the financial best interest of the controlling stockholder. In managing the business affairs of MGM, Mr. Ladd, and those he

93. Credit Lyonnais, 1991 Del. Ch. LEXIS 215, at *107.

94. Id

95. See id. at $* 106$.

96. Id. at $* 107$.

97. Id.

98. See id. at *108.

99. Id. at *108. 
appointed owed their supervening loyalty to MGM, the corporate entity. It was not disloyal for them to consider carefully the corporation's interest in the [proposed asset sales] .... This I conclude they did. Mr. Parretti had gotten himself into a corner. He needed to liquidate assets to raise capital. Ladd and his team could reasonably suspect that he might be inclined to accept fire-sale prices. But the MGM board or its executive committee had an obligation to the community of interest[s] that sustained the corporation, to exercise judgment in an informed, good faith effort to maximize the corporation's long-term wealth creating capacity. ${ }^{100}$

Chancellor Allen thus appears to suggest that directors of a financially distressed corporation have a duty not solely to shareholders, but to the "community of interests" that "sustained the corporation."

\section{c. Critic Lyonnais}

Credit Lyonnais has received much attention, most of it critical. The chief criticism is that the holding of the case-if there is one-creates uncertainty. ${ }^{101}$ Uncertainty is viewed as a function of both timing and economics. Thus, there has been much discussion of when a duty to creditors arises, ${ }^{102}$ and what kind of financial distress might occasion such a duty. ${ }^{103}$

Viewed in terms of timing and financial condition, Credit Lyonnais was something of a breakthrough. It moved the point at which duties to creditors arise to an earlier time than previously imagined by the event/condition paradigm. Under Credit Lyonnais, neither an event nor a condition need occur for a duty to creditors to arise. Merely being "in the vicinity" of a condition will suffice. This condition will axiomatically arise prior to insolvency, although at what point is hardly clear. ${ }^{104}$

While the principal purpose of this Article is to determine which creditors should benefit from a directorial duty, the timing problems created

100. Id. at *108-*09 (footnotes omitted).

101. Barnett, supra note 2, at 465 (characterizing the vicinity of insolvency as a "fuzzy concept"); Barondes, supra note 2, at 72; Hartman, supra note 2, at 1766; Lin, supra note 2, at 1512 (characterizing the vicinity of insolvency as "ill-defined"); Morris, supra note 2, at 67-68; McDonnell, supra note 2, at 178; Nicholson, supra note 2, at 575 (viewing the vicinity of insolvency exception as "regrettably ambiguous in its timing and scope"); Rao supra note 2, at 62-64 (viewing the vicinity of insolvency as "broad and ambiguous"); Schwarcz, supra note 7, at 672 (noting the valuation difficulties); Shaffer, supra note 2, at 512-20 (noting the complexities of defining corporate insolvency).

102. Shaffer, supra note 2, at 546; Trost, supra note 77 , at 290.

103. See, e.g., Rao, supra note 2, at 62 ("The terms 'financial distress' and 'insolvency' are broad and ambiguous.").

104. This is one reason that I decline to define the kind of distress needed to give rise to duties to creditors. 
by Credit Lyonnais warrant consideration. The creditors that would benefit from a duty would likely be determined by the timing and circumstances under which duties arise. Determining the identities of the low VCE creditors discussed in the introduction to this Article will likely be more difficult when a firm is marginally solvent than when it commences a liquidation. The decision to liquidate will usually flow from a recognition that the firm is so overwhelmed by known liabilities that it cannot continue. When a firm is marginally solvent, by contrast, many claims, including those that may lead to the conclusion that the firm is distressed, will be contingent and/or unliquidated. For example, the firm may not be currently liable for a mass tort, even though it is subject to a suit that would lead to a judgment well in excess of firm assets if upheld on appeal. Do duties to creditors arise when suit is commenced? When judgment is entered? At some prior time, when the harm is done? At any of these times, the very liabilities that might lead to insolvency (or marginal insolvency) would be most difficult to determine, both in terms of the amount and the identity of the creditor. ${ }^{105}$

Notwithstanding ambiguity about timing, a central though unarticulated feature of the event/condition paradigm is a particular view of the relationship between duty and priority in right of payment. There is an assumption from Wood through Credit Lyonnais that as the firm deteriorates financially, creditors displace shareholders as residual rights bearers. "[W] hen a corporation enters the zone of insolvency," the U.S. District Court for the district of Delaware recently observed, "the creditors-and not just the shareholders-are residual risk bearers whose recovery is dependent upon business decisions of the directors." ${ }^{\text {"106 }}$ Creditors are in a sense subrogated to the rights of shareholders of the distressed firm. The directors are, that court noted, "playing with the creditors['] money."107

Yet this is true only if creditors have a prior (and better) entitlement to firm assets in the first place. In other words, it is priority in right of payment that stands behind the determination that directors of the distressed firm owe duties to creditors.

105. As discussed in Part IV.B.3, infra, the term "claim" is typically defined quite broadly, to include contingent and unliquidated claims. See, e.g., 11 U.S.C. § 101(5) (2000) (defining claim).

106. Official Comm. of Unsecured Creditors of Hechinger Inv. Co. of Del. Inc. ex rel. Hechinger Inv. Co. of Del. Inc. v. Fleet Retail Fin. Group, 274 B.R. 71, 89 (D. Del. 2002).

107. Id. A similar sentiment appears in United Kingdom law. See Andrew Keay, The Duty of Directors to Take Account of Creditors' Interests: Has It Any Role to Play? J. Bus. L. 379, 385 (July 2002) ("If a company is insolvent or doubtfully solvent 'the interests of the company are in reality the interests of existing creditors alone."') (footnote omitted). 


\section{The Efficiency Paradigm}

Priority and duty also plot a parallel course through the second important explanation of directorial duties to creditors, the efficiency paradigm. Unlike prior cases (and most commentary) on duties to creditors, Credit Lyonnais explicitly oriented its analysis of options available to directors of the distressed corporation around a model of economic efficiency. Whether Chancellor Allen chose the right model, and what that model might mean, have formed the basis of most of the better academic writing about Credit Lyonnais.

In a now famous footnote Chancellor Allen set forth what has become a standard organizing structure for any efficiency analysis in the corporate distress context. ${ }^{1.8}$ There, he suggested that the board of a distressed corporation could take one of three courses: (i) a very risky course, with a low probability of success, that would produce the greatest return, paying creditors in full and leaving significant equity for shareholders (path 1); (ii) a moderately risky course that would offer a higher probability of success but a lower payoff, so that creditors would be paid in full, leaving a lower return on equity (path 2); or (iii) a least risky course in which creditors are virtually certain to be paid in full, but which would leave little or no equity (path 3). ${ }^{109}$

108. See generally Credit Lyonnais Bank Nederland, N.V. v. Pathe Communications Corp., No. 12150, 1991 Del. Ch. LEXIS 215 n.55 (Del. Ch. Dec. 30, 1991).

109. This is a simplified explanation of the footnote, which offers a hypothetical in order to show that "the possibility of insolvency can do curious things to incentives, exposing creditors to risks of opportunistic behavior and creating complexities for directors." Id. at *108 n.55. The hypothetical assumes a corporation with a single asset-a significant judgment against a solvent corporation. The judgment is on appeal. The corporate plaintiff has only a single class of creditors, bondholders owed $\$ 12$ million. $l d$. at $* 108$.

Chancellor Allen then suggests three possible outcomes, with varying degrees of likelihood: (i) 25 percent chance of affirmance, (ii) 70 percent chance of modification, and (iii) 5 percent chance of reversal. Id. After discounting for these possible outcomes, he suggests that the board would assume that the current value of the judgment was $\$ 15.55$ million. Id. This would leave equity of around $\$ 3.55$ million after satisfaction of the $\$ 12$ million claims of the bondholders. Id.

The problem posed in the hypothetical was this: What sort of settlement offer should the directors accept, and on what basis? A settlement offer of $\$ 12.5$ million or $\$ 17.5$ million would, Chancellor Allen surmised, be rejected by a board that viewed itself as solely bound to act on behalf of shareholders because shareholders would view any offer of less than $\$ 21.75$ million as inadequate. Id. at * $108 \mathrm{n} .55$. Chancellor Allen came to this surmise based on the discounted values of the various possible outcomes of the appeal;

[T]he litigation alternative, with its $25 \%$ probability of a $\$ 39$ million outcome to [the shareholders] ( $\$ 51$ million - $\$ 12$ million [=] $\$ 39$ million) has an expected value to the residual risk bearer of $\$ 9.75$ million ( $\$ 39$ million x $25 \%$ chance of affirmance), substantially greater than the $\$ 5.5$ million available to them in the settlement.

Id. at $* 108$ n. 55 . 
The great bulk of academic literature on duties to creditors focuses on this trilogy of options, and considers it principally from an economic perspective: Which of these options is most "efficient"? Efficiency analyses can thus be organized into three categories, which roughly parallel the three choices suggested in Credit Lyonnais: (i) shareholder maximization (approximating path 1); (ii) entity maximization (approximating path 2); or (iii) creditor maximization (approximating path 3 ).

What efficiency means in this context is not entirely clear. ${ }^{110}$ Nor is it clear that economic concepts of efficiency will lead to satisfactory directorial decisionmaking ex ante, or fair and equitable scrutiny ex post. Nevertheless, it is clear that in many respects the efficiency analysis is asking a much more subtle and important question: By asking for whom firm value should be maximized (whose interests should have primacy) the efficiency paradigm is asking, to whom should duty run? Or, to use the jargon, should the directorial duty to maximize value "shift" to creditors or remain with shareholders?

\section{a. Shareholder Maximization-No Shift}

The shareholder maximization norm is the dominant theoretical approach to directorial duties within and without the insolvency context. ${ }^{111}$ On this view,

\footnotetext{
Wittingly or not, Chancellor Allen was postulating an economic solution to the problem presented in In re Central Ice Cream Co., 59 B.R. 476, 488 (Bankr. N.D. Ill. 1985), affd, 62 B.R. 357 (N.D. Ill. 1986), where the debtor's sole asset was a verdict against McDonald's Corporation for $\$ 52$ million. Before McDonald's motion for judgment notwithstanding the verdict was decided, McDonald's offered $\$ 15.5$ million in settlement. Id. at 482-83. That amount was sufficient to pay creditors in full, but left the estate with only $\$ 1$ million to $\$ 3$ million, the bulk of which probably would have been applied to expenses of administration. The bankruptcy court approved the settlement over the objection of shareholders. Id. at 492; see also Lynn M. LoPucki \& William C. Whitford, Corporate Govemance in the Bankruptcy Reorganization of Large, Publicly Held Companies, 141 U. PA. L. REV. 669, 784 n.368 (1993) (discussing the Central Ice Cream case).

110. The analysis of economic efficiency usually begins with a recitation of the theories of R.H. Coase. See Coase, supra note 34, at 386. Coase, of course, taught that "the distinguishing mark of the firm is the supersession of ... price...." Id. at 389. For other important foundational works in this approach, see Michael C. Jensen \& William H. Meckling, Theory of the Firm: Managerial Behavior, Agency Costs, and Ounership Structure, 3 J. FIN. ECON. 305, 308-10 (1976).

111. See MiCHAEL P. DOOLEY, FUNDAMENTALS OF CORPORATION LAW 97 (1995) (suggesting that scholars "generally agree[ ] ... that management's principal fiduciary duty is to maximize the return to the common shareholders"); Bainbridge, Board as Nexus, supra note 35, at 5 ("[M]ost corporate law scholars today embrace some variant of shareholder primacy."); Margaret M. Blair \& Lynn A. Stout, A Team Production Theory of Corporate Law, 85 VA. L. REV. 247, 287 (1999) (" $[M]$ ost contemporary corporate scholars tend to assume that directors' proper role is to maximize the economic interests of the corporation's shareholders.") [hereinafter Blair \& Stout, Team Production Theoryl; FRANK H. EASTERBROOK \& DANIEL R. FISCHEL, THE ECONOMIC STRUCTURE OF CORPORATE LAW, 90-91 (1991) [hereinafter EASTERBROOK \& FiSCHEL, ECONOMIC Structure]; Daniel R. Fischel, The Corporate Govemance Movement, 35 VAND. L. REV. 1259, 1263-65 (1982); Jonathan R. Macey, An Economic Analysis of the Various Rationales for
} 
all efforts of firm participants-for example, directors and officers-should be directed toward producing the greatest return to those who hold the stock of the company. ${ }^{112}$ Courts should assume that parties ex ante would have structured their affairs in the most efficient way possible which, in turn, means that directorial efforts should be geared towards shareholders.

On the shareholder maximization view, directors should be concerned primarily with producing maximum value for shareholders because, "[a]s the residual claimants, the shareholders are the group with the appropriate incentives ... to make discretionary decisions." ${ }^{113}$ As residual claimants, shareholders are said to "incur most of the marginal costs [and] [t]herefore have the right incentives to exercise discretion."114 All other claimants-those characterized as having "fixed claims on the [corporate] income stream"115 — should receive far less in the way of benefit from any given undertaking by the firm. The assumption seems to be that if the corporation can generate sufficient wealth to pay shareholders, then it is reasonable to infer that all prior stakeholders-including creditors—have been, or will be, paid, too.

Perhaps more importantly, directorial efforts should run exclusively to shareholders, at least while the firm is solvent. That is, independent of whether one calls the obligation contractual, fiduciary, or something else, the only beneficiaries should be shareholders. ${ }^{116}$ Thus, efforts of the directors of a

Making Shareholders the Exclusive Beneficiaries of Corporate Fiduciary Duties, 21 STETSON L. REV. 23, 23-24 (1991) [hereinafter Macey, Exclusive Beneficiaries].

112. See A.A. Berle, Jr., Corporate Powers as Powers in Trust, 44 HARV. L. REV. 1049, 1049 (1931) ("IA]ll powers granted to a corporation ... [are] at all times exercisable only for the ratable benefit of all the shareholders as their interest appears."); see also ADOLPH A. BERLE \& Gardiner C. Means, THe Modern Corporation and Private Property (4th ed., Harcourt, Brace \& World, Inc. 1968) (1932). Shareholder maximization (or "primacy" in the words of Berle and Means) is sometimes contrasted with "managerialism," the view that corporate officers (managers) - rather than directors-are the primary figures around which the law should channel corporate efforts. See e.g., AlFred D. CHANDLER, JR., THE VISIBLE HAND: THE MANAGERIAL REVOLUTION IN AMERICAN BUSINESS (1977); William W. Bratton, The New Economic Theory of the Firm: Critical Perspectives from History, 41 STAN. L. REV. 1471, 1474-80 (1989).

113. Easterbrook \& Fischel, Voting, supra note 31, at 403; see also Jonathan R. Macey, Externalities, Firm-Specific Capital Investments, and the Legal Treatment of Fundamental Corporate Changes, 1989 DUKE L.J. 173, 175 (1989).

114. Id.

115. Easterbrook \& Fischel, Voting, supra note 31, at 403.

116. See, e.g., Deborah A. DeMott, Beyond Metaphor: An Analysis of Fiduciary Obligation, 1988 DUKE L.J. 879, 917 (treating the interests of a corporation as identical to the interests of its shareholders); Daniel J.H. Greenwood, Fictional Shareholders: For Whom Are Corporate Managers Trustees, Revisited, 69 S. CAL. L. REV. 1021, 1023 (1996) ("[V]irtually the sole task of corporate law is to ensure that managers act as agents for the shareholder owners."); Jonathan R. Macey \& Geoffrey P. Miller, Corporate Stakeholders: A Contractual Perspective, 43 U. TORONTO L.J. 401 (1993); David Millon, Communitarians, Contractarians, and the Crisis in Corporate Law, 50 WASH. \& LEE L. REV. 1373, 1374 (1993) (“'S]hareholder primacy has served as corporate law's governing 
financially healthy firm should run exclusively to benefit shareholders, and no one else. ${ }^{117}$

The literature on directors' duties to creditors embraces shareholder maximization warmly. The leading example of this approach appears in a 1993 article by Laura Lin, arguing that the "most promising"118 solution to the problems posed by Credit Lyonnais would require directors of the distressed corporation" to "maximize shareholder interests regardless of the firm's financial condition."120 Only if creditors "contract specifically for directors to maximize the company's value" would directors have a duty to do anything other than maximize shareholder value. ${ }^{121}$ Thus, they should presumptively take the high risk/high reward path (path 1), because shareholders would have the most to gain and the least to lose from such a choice (their upside being unlimited, and their costs already sunk). Unless creditors obtained an

norm for much of this century."); Roberta Romano, Corporate Law and Corporate Governance, 5 INDUS. CORP. CHANGE 277, 279 (1996) ("[T]he board represents the interests of shareholders and not other constituents."); D. Gordon Smith, The Shareholder Primacy Norm, 23 J. CORP. L. 277, 280 (1998) ("The assumption that the shareholder primacy norm is a major factor in the ordinary business decisions of boards of directors of modern, publicly traded corporations is pervasive in modern corporate law scholarship."); Committee on Corporate Laws, ABA, Other Constituencies Statutes: Potential for Confusion, 45 BUS. LAW. 2253, 2269 (1990).

117. This position is sometimes bolstered by the claim that shareholders "own" the corporation. A famous example from the popular press is Milton Friedman, The Social Responsibility of Business Is to Increase Its Profits, N.Y. TIMES MAG., Sept. 13, 1970, at 32, 32-33, 122-26 (characterizing corporate shareholders as "the owners of the business"). Lynn Stout provides a withering critique of this view. Lynn A. Stout, Bad and Not-So-Bad Arguments for Shareholder Primacy, 75 S. CAL. L. Rev. 1189, 1191 (2002) ("A lawyer would know that the shareholders do not, in fact, own the corporation. Rather they own a type of corporate security commonly called 'stock.") [hereinafter Stout, Not-So-Bad]. See also Stephen M. Bainbridge, In Defense of the Shareholder Wealth Maximization Norm: A Reply to Professor Green, 50 WASH. \& LEE L. REV. 1423, 1427-28 (1993).

Stout suggests that, while most arguments for shareholder primacy "are, as a positive matter, inaccurate, incorrect, and unpersuasive to the careful and neutral observer," Stout, Not-So-Bad, supra, at 1190, the best justification for the position comes from a recognition that it provides a "second-best solution that is good for all the stakeholders in the firm, because it limits what might otherwise be the runaway agency costs that might be incurred by all if directors were not held to a clear and easily observed metric of good corporate governance." Id. at 1200.

118. Lin, supra note 2, at 1510.

119. Like me, and many other writers, Lin ignores the difficulty of defining insolvency. See id. at 1498-95; Barondes, supra note 2, passim.

120. Lin, supra note 2, at 1500 . Lin's position is actually somewhat unclear. Although she views shareholder maximization as the "most promising" approach, the introduction to the article states that "directors should maximize the company's value even when the company is in financial distress." Id. at 1487 (emphasis supplied). This sounds much more like path 2 than path 1 . Nevertheless, since she does not develop or argue for path 2, my sense is that she prefers path 1 .

121. Id. 
agreement that directors would, on financial distress, act for their benefit, creditors would have no basis for suit against the directors. ${ }^{122}$

This rule would, Lin acknowledges, place the costs and risks of contracting and monitoring on creditors. ${ }^{123}$ Nevertheless, she argues that creditors are in the best position to absorb these costs: "[B]anks and other commercial lenders usually specialize in providing funds to companies in certain industries ... [and are thus able] to evaluate and monitor the firm's major decisions." ${ }^{124}$ Moreover, these lenders "have the expertise to appraise both the firm-specific and industry-specific risks (such as the adequacy of the corporate borrower's financial ratios) and to negotiate tailor-made provisions to protect their own interests." ${ }^{\text {125 }}$ Finally, "fewer lenders are involved for each term loan and for each issuance of privately placed debt securities. These creditors have [a] greater incentive to monitor managerial compliance with the loan agreement because of their larger economic stake in the transaction."126

The obvious problem here is that Lin assumes the existence of only one type of creditor-one with high levels of volition and cognition. As discussed in Part III, low VCE creditors will not usually have significant expertise in the debtor's industry (nor would that expertise necessarily help them much). They will likely not have had the opportunity to negotiate tailor-made provisions for their protection or to monitor the debtor or its managers.

122. This proposal is curious, for several reasons. First, it is not clear what it means for directors to agree to maximize firm value. If it means that the corporation should agree to maintain a certain level of profitability, it is obviously correct. It is obvious because financial covenants are virtually universal features of loan agreements and bond indentures. If, instead, it means that directors themselves should agree to incur liability to creditors if the directors fail to maximize value for them, Lin asserts a more interesting, but troublesome, proposition. It seems highly unlikely that directors would ever agree to incur such liability; directors (understandably) do not view themselves as guarantors of corporate performance.

Second, it is not clear how such agreements by directors would fare against the duties or other obligations ordinarily owed to shareholders. The shareholder primacy norm ordinarily requires directors to maximize firm value for the benefit of shareholders. Directors should not be permitted to deviate from this orientation without good reason. It is not clear from Lin's discussion how or why contracting with creditors in the way she suggests is consonant with the shareholder maximization position she apparently embraces.

123. Lin, supra note 2, at 1501-02. She claims, oddly, that "creditors probably would not have bargained for business strategies aimed at minimizing risk even if management presented the option at the outset." Id. at 1501 . This seems wrong. The many covenants common in loan agreements and bond indentures on cash flow, asset/liability ratios, solvency, extraordinary transactions, etc. all contradict Lin's claim. See generally Clifford W. Smith, Jr. \& Jerold B. Warner, On Financial Contracting: An Analysis of Bond Covenants, 7 J. FIN. ECON. 117 (1979).

124. Lin, supra note 2, at 1502.

125. Id.

126. Id. Professor Stilson takes a similar approach. See Stilson, supra note 2, at 104, 114. 
In any case, it should be noted that shareholder maximization in general has long had its critics. Some question its propriety as a norm. ${ }^{127}$ Others question its merits on efficiency grounds. ${ }^{128}$ For example, a recent article by Thomas Smith argues that, if the goal is economic efficiency, shareholder primacy is self-defeating because rational investors-cognizant of the Capital Asset Pricing Model (CAPM) ${ }^{129}$-recognize that they should be invested in the entire spectrum of corporate obligations, and not just equity. ${ }^{130}$ Still others have observed that justifying shareholder primacy on grounds that shareholders are residual claimants is simply not the way the real world works, ${ }^{131}$ or that it is really limited in application to one set of circumstances: when, as in Van Gorkom or Revlon, there is a contest for control of the firm. ${ }^{132}$

\section{b. Entity Maximization-Expanding Duties}

Whatever its merits, shareholder maximization is not the only approach directors may take when considering how to guide the distressed firm. Rather, a number of authors-and perhaps Chancellor Allen in Credit Lyonnais-believe that directors have a duty to maximize the value of the entity when it is in or near financial distress. In other words, they should take path 2 of Credit Lyonnais and recognize that duty should not remain solely with shareholders, but should instead expand to embrace creditors as well. ${ }^{133}$

127. See, e.g., David Millon, New Game Plan or Business as Usual? A Critique of the Team Production Model of Corporate Law, 86 VA. L. ReV. 1001, 1001-04 (2000); Stout, Not-So-Bad, supra note 117 , at 1190.

128. See, e.g., Margaret M. Blair \& Lynn A. Stout, Director Accountability and the Mediating Role of the Corporate Board, 79 WASH. U. L.Q. 403, 407 (2001); Bruce Chapman, Trust, Economic Rationality, and the Corporate Fiduciary Obligation, 43 U. TORONTO L.J. 547, 568-88 (1993); John C. Coffee, Jr., The Uncertain Case for Takeover Reform: An Essay on Stockholders, Stakeholders and Bust-Ups, 1988 WIS. L. REV. 435,439 (1988); G. Mitu Gulati et al., Connected Contracts, 47 UCLA L. REV. 887, 943 (2000).

129. See Sinith supra note 34, at 117. The Capital Asset Pricing Model (CAPM) is explained in greater detail in BURTON G. MALKIEL, A RANDOM WALK DOWN WALL STREET 251-76 (1996).

130. See Smith, supra note 34, at 217 ("Investors who are rational in the CAPM sense would hypothetically agree to a gap-filling principle, but it would not be to 'maximize shareholder value"').

131. See Peter Coy, High Turnover, High Risk, Bus. WK., Apr. 11, 2002, at 24 ("[T]heory [of shareholder primacy] doesn't match reality.").

132. See Smith, supra note 116, at 279-80 ("The shareholder primacy norm is nearly irrelevant to the ordinary business decisions of modern corporations .... Outside the takeover context ... [the shareholder primacy norm] is muted by the business judgment rule."). Of course, bankruptcy may in fact place the firm "in play," albeit for very different reasons than those envisioned by Van Gorkom and Revlon.

133. See Credit Lyonnais Bank Nederland, N.V. v. Pathe Communications Corp., No. 12150, 1991 Del. Ch. LEXIS 215, at *107-*09 (Del. Ch. Dec. 30, 1991). 
Recall that Credit Lyonnais did not counsel directors to take path 1 (the shareholder maximization path, with the greatest potential returns, but imposing the greatest potential loss on creditors) or path 3 (the least risky path, with the greatest assurance that creditors will be repaid). Rather, Chancellor Allen suggested that directors should reject both extremes and take the middle course (path 2) ${ }^{134}$ This would only be possible, Chancellor Allen observed:

[B]y directors who are capable of conceiving of the corporation as a legal and economic entity. Such directors will recognize that in managing the business affairs of a solvent corporation in the vicinity of insolvency, circumstances may arise when the right (both the efficient and the fair) course to follow for the corporation may diverge from the choice that the stockholders (or the creditors, or the employees, or any single group interested in the corporation) would make if given the opportunity to act. ${ }^{135}$

This language suggests that directors of the marginally solvent corporation should act not with the interests of a single constituency or class of constituents in mind, but instead with those of the entire corporate enterprise in mind. The entity-or the community of interests it represents-should have primacy.

A number of writers have argued that, when a firm is distressed, entity maximization is the only way to assure the most efficient result. ${ }^{136}$ Thus, following Chancellor Allen's analysis, these writers suggest that the riskiest course of action (path 1) would actually lead to decisions that are inefficient because they are excessively risky. Excessive risk-taking would follow from the fact that shareholders have the least to lose and the most to gain from

134. Id. at *108 n.55 ("[O]ne should in this hypothetical accept the best settlement offer available providing it is greater than $\$ 15.55$ million, and one below that amount should be rejected.").

135. Id.

136. See Gregory Scott Crespi, Rethinking Corporate Fiduciary Duties: The Inefficiency of the Shareholder Primacy Norm, SMU L. REV. 141, 152-53 (2002); Smith, supra note 34, at 218. In a recent article, Alon Chaver and Jesse Fried refine this approach by arguing that entity-value maximization must account for both "performance" and "payment" creditors, a distinction apparently aimed at recognizing differences between claims that are liquidated and unliquidated. See Alon Chaver \& Jesse Fried, Managers' Fiduciary Duty upon the Firm's Insolvency: Accounting for Performance Creditors, 55 VAND. L. REV. 1813 (2002). As discussed below, recognizing that not all creditors are the same is laudable, and fills an important gap in our understanding of the relationship between debt and duty. It is not, however, clear that the distinction Chaver and Fried draw teaches much. For purposes of an efficiency analysis, it is not clear why the distinction matters. Bankruptcy law, and most other insolvency-related laws, already recognize the need to value present and future-arising claims. See, e.g., 11 U.S.C. $\$ 502(\mathrm{c})(1)(2000)$ (providing for an estimation of contingent and unliquidated claims in bankruptcy). In any event, as will be demonstrated below, duty should be a response to imbalances of power, not to the amount or contingency of claims against the corporation. 
any particular course of action. Inefficiency would flow from the recklessness of playing with other peoples' (creditors') money. For equal and opposite reasons, inefficiency would also haunt giving creditors primacy (path 3). If directors followed the third Credit Lyonnais path, and only took actions that assured repayment of creditors, they would make excessively cautious investments, thereby leaving value unrealized. Inefficiency would be a function of taking too little risk. ${ }^{137}$

Thus, as Gregory Scott Crespi argues, if duties ran to the corporation as a whole, rather than to a particular constituency-for example, shareholders or creditors-duty "would preclude corporate pursuit of vicinity of insolvency projects that would have positive impacts on shareholder wealth but negative impacts on overall corporate wealth." ${ }^{\text {"138 }}$ Crespi bases his argument on Professor Smith's recent claim (discussed above) that shareholder primacy (or any particular primacy) is inefficient on the CAPM. ${ }^{139}$ Rather, rational investors should always be invested in the entire spectrum of corporate obligations, and so should be indifferent to any particular position.

Efficiency concerns are not the only basis for the entity maximization position. Other recent discussions about duty in the corporate context suggest that "team production" may be akin to entity maximization and should inform directorial decisionmaking. ${ }^{140}$ Team production occurs when two or more individuals must each contribute valuable resources to produce a single, nonseparable output. ${ }^{141}$ Under the team production approach, directors are viewed not as shareholders' exclusive agents, but as agents for the entire corporate team. This "team consists of all who make firm-specific investments and expect a share of the resulting output, including not just shareholders but also managers, employees, and possibly other groups as well., ${ }^{142}$

Team production is generally viewed as a response not to problems of duty but to agency cost (the costs of feckless or faithless agents). Nevertheless,

137. Creditor maximization is nevertheless the prevailing choice of courts. See Schwarcz, supra note 7 , at $667-68$.

138. Crespi, supra note 136, at 148.

139. See id. at 143 ("My analysis builds directly upon a recent and important article by Thomas Smith.") (citing Smith, supra note 34).

140. Blair \& Stout, Team Production Theory, supra note 111; Margaret M. Blair \& Lynn A. Stout, Team Production in Business Organizations: An Introduction, 24 J. Corp. L. 743, 745 (1999) (describing the "team production" problem). See generally Symposium, Team Production in Business Organizations, 24 J. CORP. L. 743 (1999).

141. Blair \& Stout, Team Production Theory, supra note 111, at 265-76 (discussing the team production contracting problem); see also CHARLES R. O'KELLEY, JR. \& ROBERT B. THOMPSON, CORPORATIONS AND OTHER BUSINESS ASSOCIATIONS: CASES AND MATERIALS 7-9 (3d ed. 1999) (discussing team production in firms).

142. Blair \& Stout, Trust, supra note 39, at 1757, n.45 (citing Blair \& Stout, Team Production 
it also suggests that directors take a certain posture toward corporate participants other than shareholders. Margaret Blair and Lynn Stout have thus suggested that it may explain the expanding duties view of Credit Lyonnais. ${ }^{143}$ Implicit in the team production model is the assumption that no particular group has primacy. Rather, corporate directors are simply "mediating hierarchs whose job is to balance team members' competing interests in a fashion that keeps everyone happy enough that the productive coalition stays together."144 Thus, the question becomes how much power- "fiat" in the words of one author ${ }^{145}$-directors should have while remaining immune from later judicial scrutiny.

The entity maximization view has a certain appeal, on both efficiency and fairness grounds. ${ }^{146}$ If one distills business reality down to certain understandings of rational economic behavior, path 2 would be most efficient, because it does the best job of marrying risk and reward: It cancels out the excess risk of path 1 and the excess caution of path 3. Moreover, by encouraging concern for all corporate constituents, or at least immunizing directors from the claims of any single group, one senses a certain kind of fairness. Like Goldilocks, Chancellor Allen might say that path 2 is neither too hot nor too cold, but just right. By expanding duty to embrace the entire "community of interests," path 2 would strike a happy medium in terms both economic and normative.

Tempting as it may be, the entity maximization approach creates enormous difficulties. First, even if one accepts that this is merely a model, it is not at all clear that it does more than restate the formalistic truism that directors owe duties to the firm and not (necessarily) to its particular constituents. That is, while we may often speak as if directors owe duties to or for the benefit of shareholders, it is well known that, in the first instance, they owe their duty to the corporation itself, even though it may be a fictitious

Theory, supra note 111, at 276-87). It is not clear whether "other groups" would include low VCE creditors, such as tort claimants and taxing authorities.

143. See Blair \& Stout, Team Production Theory, supra note 111, at 297 ("II]nsolvency can impose terrible costs on other members of the corporate coalition-in particular, employees and creditors-who stand to lose all or part of their firm-specific investment.").

144. Id. at 280-301.

145. Bainbridge, Board as Nexus, supra note 35, at 6 .

146. Indeed, Chancellor Allen supports his preference for entity maximization on both sets of grounds. See Credit Lyonnais Bank Nederland, N.V. v. Pathe Communications Corp., No. 12150, 1991 Del. Ch. LEXIS 215, at *108 n.55 (Del. Ch. Dec. 30, 1991) ("the right (both the efficient and the fair) course to follow for the corporation....") (emphasis added). 
entity ${ }^{147}$ While this may "tend[ ] towards mindless formalism," ${ }^{118}$ it nevertheless repeats an axiom that is true, independent of financial condition. ${ }^{149}$

Second, one must contend with the problem, observed in Credit Lyonnais, that creditors and shareholders of the distressed firm often have antithetical interests. ${ }^{150}$ The oppositional nature of these interests presents the potential for double binds that are inherently unfair to directors, and that have yet to enjoy a satisfactory judicial response. For example, in Brandt v. Hicks, Muse $\mathbb{B}$ Co. (In re Healthoo International, Inc.), ${ }^{151}$ a case that followed in the wake of Credit Lyonnais, the Bankruptcy Court for the District of Massachusetts held that directors of a solvent corporation breached a duty of care to creditors by approving a leveraged buyout that ultimately failed, and led to bankruptcy. ${ }^{152}$ The court was not moved by the directors' claims that they were forced to approve the LBO by such shareholder maximization decisions as Van Gorkom and Revlon. These duties to shareholders did not apply, the court reasoned, because even though the company had been the subject of a proxy contest, "[n]o bidding war was going on for Healthco." "153

"Moreover and most important," Judge Queenan reasoned:

[T]he Delaware court did not say in Revlon, nor has it said in any other decision, that directors have an obligation to benefit stockholders at the expense of creditors. To the contrary, as we have seen, the

147. See Official Comm. of Unsecured Creditors v. R.F. Lafferty \& Co., 267 F.3d 340, 348 (3d Cir. 2001) ("[I]njury to the corporate body is legally distinct from an injury to another person.").

148. Bainbridge, Board as Nexus, supra note 35, at 16.

149. It is a proposition with at least some current academic support. See id. at 16 ("[P]erhaps some deference should be shown the corporation's status as a legal person."); Mark J. Roe, Bankruptcy and Debt: A New Model for Corporate Reorganization, 83 COLUM. L. REV. 527, 583 (1983) (improper directorial action in insolvency context "might be avoided by a concept of corporate duty of officers and directors to the abstract firm, not just to its shareholders.").

150. See, e.g., Barondes, supra note 2, at 55; Victor Brudney, Corporate Bondholders and Debtor Opportunism: In Bad Times and Good, 105 HARV. L. REV. 1821, 1837 n.49 (1992) [hereinafter Brudney, Corporate Bondholders] ("[T]he conflict between the interests of stockholders and bondholders does not permit management to be the agent of both in a manner consistent with fiduciary principles."); Rao, supra note 2 , at 56 ("[N]one of the extant control devices can fully harmonize the interests of managers [who will prefer protecting creditors] and shareholders."); Stilson, supra note 2 , at 5 ("[C]ase law fails to address whether the duty to creditors gains ascendancy over, or operates as a complement to, traditionalist directorial obligations to stockholders.").

Commencing a case under Chapter 11 of the Bankruptcy Code may not eliminate the conflict. Lynn LoPucki and William Whitford observe that in large company bankruptcies, "[incumbent managers'] decisions were often between courses of action that would serve either the interests of their shareholders or the interests of their creditors, one at the expense of the other." LoPucki \& Whitford, supra note 109, at 672.

151. 208 B.R. 288 (Bankr. D. Mass. 1997), aff d, 310 F.3d 9 (1st Cir. 2002).

152. Id. at 300,305 .

153. Id. at 300-01. This seems wrong. The leveraged buyout was consummated as a protective strategy in the face of an impending hostile bid for control, evidenced by the proxy contest. 
Delaware courts recognize that directors breach their fiduciary obligations when they authorize a transaction which prejudices creditors. ${ }^{154}$

In short, to say that duty runs only to the entity and not to its constituents masks the reality that directorial decisions in this context will often benefit one group at the expense of another, and the group harmed may be inspired to sue for breach of duty. It is, as a recent article discussing a somewhat different problem suggests, "dangerous to ignore the reality that firms can transact only through individuals." 155

Third, entity maximization may mean that we read the duty of care entirely out of corporate law when the firm is distressed. That is, by freeing directors from having to act on behalf of any particular group, we are perhaps saying that they are immune from ex post judicial determinations that their actions or omissions breached a duty of care to that group. ${ }^{156}$ By a parity of reasoning, the entity maximization view may instead mean that the duty of care is understood in exclusively economic terms: Did the act or omission maximize entity wealth? If so, the directors should be immune from suit. If not, perhaps the directors should have something to worry about. In either case, the actual care, diligence, and competence of directors would not matter; only the result would count.

These problems with the entity maximization position may help to explain at least one ambiguity in Credit Lyonnais: Which duty-care or loyalty-was at issue? Recall that Chancellor Allen began the duty discussion by observing that he was going to "pass over the question whether the existence of this conflict affects the availability of the business judgment form

154. Id. at 301. This is not so. Many Delaware decisions hold that corporate directors can-and perhaps should-make decisions that benefit shareholders at the expense of corporate creditors. A typical statement appears in Katz v. Oak Industries Inc.:

It is the obligation of directors to attempt, within the law, to maximize the long-run interests of the corporation's stockholders; that they may sometimes do so "at the expense" of others (even assuming that a transaction which one may refuse to enter into can meaningfully be said to be at his expense) does not for that reason constitute a breach of duty. It seems likely that corporate restructurings designed to maximize shareholder values may in some instances have the effect of requiring bondholders to bear greater risk of loss and thus in effect transfer economic value from bondholders to stockholders.

Katz v. Oak Indus. Inc., 508 A.2d 873, 879 (Del. Ch. 1986) (citations omitted); see also United States v. Jolly, 102 F.3d 46, 48 (2d Cir. 1996); Metropolitan Life Ins. Co. v. RJR Nabisco, Inc. 716 F. Supp. 1504, 1524-25 (S.D.N.Y. 1989); Simons v. Cogan, 549 A.2d 300, 303-04 (Del. 1988).

155. Gulati et al., supra note 128 , at 891 .

156. The duty of loyalty may, of course, remain robust because directors should not benefit themselves at the expense of the corporation. This would then be consistent with the views of certain courts that directors should never be liable for a breach of duty to creditors absent selfdealing. See supra note 73. 
of judicial review of controversial executive committee decisions."157 This language suggests that, even though he may have passed over it, he had in mind a duty of care, since the business judgment rule is a defense only to that cause of action. ${ }^{158}$ Curiously, this absolution flowed from the fact that the bank-appointed directors were not "disloyal" to Parretti, the majority shareholder, by declining to sell assets at "fire sale prices." little to do with maximizing value. The failure to maximize value is usually the root of the claim that directors breached a duty of care, not loyalty. ${ }^{160}$ In the end, Chancellor Allen appears to have punted: "Under any approach, I find that the executive committee decisions were valid and did not represent a breach of duty." ${ }^{\text {"161 }}$

A final factor compounds the problematic nature of the entity maximization view of Credit Lyonnais: Chancellor Allen's punt may have been a fake. While Credit Lyonnais may counsel path 2, that is not in fact what the decision does. ${ }^{162}$ Rather than promoting entity primacy-and the expanding duty model-the holding of Credit Lyonnais appears more consistent with a creditor primacy model, meaning that duty should shift exclusively to creditors.

This becomes clear when considering the result of the case, which was that the bank-which was in the unusual position of controlling the company-was, in fact, entitled to do as it wished to maximize its self-interest (selling off assets to pay debts) without necessarily maximizing value for the majority shareholder. Moreover, Chancellor Allen's conclusion that the bank was acting in the interests of the entire corporate community seems implausible, if only because the bank was acting antithetically to the expressed desires of the principal shareholder, obviously a member of the corporate community. ${ }^{163}$ Rather, consistent with the restructuring agreement, the bank was simply trying to get paid.

In other words, while Credit Lyonnais may sound as if it advocates an expansive view of duty, it in fact seems to hold that duty truly shifts to creditors, who are to be permitted (at least on the odd facts of the case) to control

157. Credit Lyonnais Bank Nederland, N.V. v. Pathe Communications Corp., No. 12150, 1991 Del. Ch. LEXIS 215, at *108 (Del. Ch. Dec. 30, 1991).

158. See supra notes 14-19 and accompanying text.

159. Credit Lyonnais, 1991 Del. Ch. LEXIS 215, at *109.

160. See Revlon, Inc. v. MacAndrews \& Forbes Holdings, Inc., 506 A.2d 173, 175-76 (Del. 1985); Smith v. Van Gorkom, 488 A.2d 858, 893 (Del. 1985).

161. Credit Lyonnais, 1991 Del. Ch. LEXIS 215, at *108.

162. In other words, it may be the worst kind of dicta-not simply irrelevant to the holding, but actually contrary to it.

163. Reading between the lines, it would seem that Chancellor Allen was rightly disgusted with Parretti's behavior. It is not, however, clear why Parretti's repugnance warranted a new approach to directorial duties. 
the corporation and to take the actions they deem best, without apparent regard to the interests of shareholders. Thus, if one believes the rule of Credit Lyonnais is in the result, rather than the footnotes, the case may not mean that directors have a duty to the entire distressed corporate entity. Rather, they should act in the best interests of creditors, whatever those might be. In other words, it might really stand not for entity maximization, but for creditor maximization.

\section{c. Creditor Maximization-True Shift}

Although generally viewed as inefficient, the creditor maximization model apparently dominates most judicial decisions. ${ }^{164}$ In a sense, creditor maximization reflects the general view that fiduciary duties shift to creditors rather than expand to embrace the entire community of corporate stakeholders. ${ }^{165}$ Implicit in the shifting duties view is the understanding that no residual duties run to shareholders, at least so long as the firm is distressed. ${ }^{166}$

Creditor maximization is viewed as inefficient for either or both of two reasons. First, as noted above, it may lead to underinvestment of firm resources. Directors concerned only about protecting the interests of creditors will, the economic thinking goes, ignore other, potentially more lucrative but risky investments, thereby foregoing potential value for shareholders. Taken to its logical conclusion, creditor maximization should mean that liquidation rather than reorganization becomes the norm; liquidation of the marginally solvent firm is, axiomatically, the only way to assure that creditors are paid in full.

Yet, compelling liquidation at insolvency (or perhaps some other kind of distress) raises serious problems, principally because it is an affront to the basic policy goals of Chapter 11 of the Bankruptcy Code, the fullest statutory regime for managing distressed firms. ${ }^{167}$ True, many respected academics would urge Congress to reformulate Chapter 11 to reduce the costs and delay of

164. See sources cited supra note 53 .

165. See, e.g., Lin, supra note 2, at 1501-02.

166. Although this Article is principally concerned with pre-bankruptcy behavior, it should be noted that in bankruptcy, "alignment of management is clearly a function of solvency," and that "managements of insolvent companies aligned with creditors far more frequently than they aligned with shareholders." LoPucki \& Whitford, supra note 109 , at 745 . Whether these same conclusions would or should hold for directors prior to bankruptcy is another matter and is, of course, the subject of this Article.

167. See H.R. REP. NO. 95-595, at 220 (1977), reprinted in 1978 U.S.C.C.A.N. 5963, 6179 ("The premise of a business reorganization [under Chapter 11] is that assets that are used for production in the industry for which they were designed are more valuable than those same assets sold for scrap."); 123 CONG. REC. H35, 444 (daily ed. Oct. 27, 1977) (statement of Rep. Rodino) ("For businesses, [Chapter 11] facilitates reorganization, protecting investments, and jobs."). 
reorganization. ${ }^{168}$ Nevertheless, it seems unlikely that even these skeptics would require directors-at penalty of personal liability—to liquidate fragile but going concerns at the onset of financial distress.

Second, duties to creditors will often be redundant with other protections arising by contract or by operation of law. The strongest example of redundancy arises where a high VCE creditor, such as a bank or a debenture holder, has a negotiated contract with the debtor. The whole point of the loan agreement or bond indenture is to protect the creditor from a failure to direct corporate efforts to maximize firm value consistent with creditor expectations. The same can be said of statutory or common law creditor protections, such as unlawful distribution or fraudulent conveyance.

Nevertheless, free from the ambiguities of the entity maximization position, creditor maximization has the virtue of a certain kind of moral clarity. It does not matter what might be best for shareholders or even the entity as such (assuming that determination is plausible). The only job is to make sure that creditors are paid.

Notwithstanding this clarity, courts that take the creditor maximization position appear prone to distorting the traditional scope and content of directorial duties. Consider Healthco again, where the business judgment rule was effectively diluted, and the duty of loyalty expanded. ${ }^{169}$ None of the Healthco directors was permitted to invoke the protection of the business judgment rule, even those who were not selling shareholders. ${ }^{170}$ This rendered the duty of care much more potent than is usually the case. ${ }^{171}$ Moreover, the nonselling shareholder directors were also found to have breached the duty of loyalty when they voted in favor of the LBO. "A director's obligation of loyalty to his corporation is not," Judge Queenan observed, "limited to subordinating his own financial interests to those of the corporation. It necessarily encompasses a duty not to place another director's financial interest above the interests of the corporation. ${ }^{172}$

168. See THOMAS H. JACKSON, THE LOGIC AND LimitS OF BANKRUPTCY LAW 209-24 (1986); Douglas G. Baird, The Uneasy Case for Corporate Reorganizations, 15 J. LEGAL STUD. 127, 128 (1986); Roe, supra note 149, at 600-02. A principal means of doing so would be to increase the frequency with which marginal firms are liquidated rather than reorganized.

169. See Brandt v. Hicks, Muse \& Co. (In re Healthco, Int'l, Inc.), 208 B.R. 288, 306-11 (Bankr. D. Mass. 1997).

170. Id. at 306.

171. Id. at 303 (stating that even shareholders who had no material interest in the transaction had "the burden of proving the LBO's fairness to the corporation ... without protection of the business judgment rule.").

172. Id. A curiosity of Healthco is that its rule would seem to use against disinterested directors the very device-cleansing votes-intended to protect them.

Healthco was not the first case to hold a director liable for breach of the duty of loyalty, even though she did not gain economically from the transaction. In Rosebud Corp. v. Boggio, 561 P.2d 
Credit Lyonnais contains its own distortions. Recall that the opinion appears intentionally vague on which duties were in question. ${ }^{173}$ However, if it was the duty of loyalty, then Credit Lyonnais offered a diluted version of it, because it is not clear that the bank-appointed directors should have passed muster. Rather, it would appear that the bank was keenly "interested" in most of the transactions the bank-appointed directors approved, including the asset sales discussed above. ${ }^{174}$ Indeed, the workout agreement would have made no sense except as a means of assuring the bank of repayment. The bank was, therefore, on both sides of many of the transactions in question-it controlled the company and it benefited from the transactions it caused.

Nor does it appear that the Credit Lyonnais transactions were cleansed by the support of informed, independent directors. Although Parretti, the controlling shareholder, had the nominal right to elect three of the five members of the board, most of the important powers of the board had been delegated to an executive committee controlled by the bank's designee, Alan Ladd, pursuant to the workout agreement. Thus, this committee, and not the entire "disinterested" board, undertook most of the actions Parretti challenged; there were no independent directors to cleanse the transactions. In any case, under the workout agreement, the bank had the right to take Parretti's stock if it believed Parretti was in breach. So, it seems highly unlikely that a majority of disinterested directors approved the transactions.

Whatever the merits of creditor maximization, efficiency analyses in general have limited value. First, and most obviously, it seems a bit simplistic to imagine that the directors of the distressed corporation would have the luxury of these choices. Distress will often mean that directors lack the time or the opportunity to recognize or to choose between various competing options. Sometimes, it is the (perceived) absence of choice that causes the

367, 369 (Colo. Ct. App. 1977), a payee on a promissory note sued the corporate maker and its two directors. The two directors had caused the corporate-debtor to sell its assets. Id. One of the directors had converted the sale proceeds, while the other had simply approved the transactions. Id. at 373 . Both were held to have breached a duty of loyalty. Id. A similar result, on a slightly different theory, was obtained in Francis v. United Jersey Bank, 432 A.2d 814, 826, 829 (N.J. 1981) (holding the director of a reinsurance company liable in negligence for failure to detect and halt corporate defalcation).

173. See supra notes 157-161 and accompanying text.

174. Compare Aronson v. Lewis, 473 A.2d 805, 812 (Del. 1984) ("[D]irectors can neither appear on both sides of a transaction nor expect to derive any personal financial benefit from it in the sense of self-dealing, as opposed to a benefit which devolves upon the corporation or all stockholders generally.") with Pogostin v. Rice, 480 A.2d 619, 624 (Del. 1984) ("Directorial interest exists whenever divided loyalties are present, or a director either has received, or is entitled to receive, a personal financial benefit from the challenged transaction which is not equally shared by the stockholders."). 
distress. By assuming away all the messiness of reality, the Credit Lyonnais trilogy, and in particular path 2, propose an approach that may be too elegant to have value in the real world.

It is thus not surprising that there is a rich literature questioning the underlying assumption that human beings are rational in the ways imagined by free market economists. ${ }^{175}$ Even those sympathetic to the free market project recognize that human intelligence is obviously imperfect: Our knowledge and rationality are always "bounded."176 There are, of course, normative critiques as well: Giving efficiency primacy causes us to neglect other, perhaps more important, values, such as fairness. ${ }^{177}$

The response to these criticisms is simple: Efficiency analysis offers a model for understanding, and perhaps predicting, human behavior in certain circumstances. Like all models, it is necessarily imperfect and reductive. Nevertheless, it contains analytic appeal. We understand this concept of efficiency, even if we do not believe it to be completely accurate or fair. We can imagine ex ante directors and ex post courts benefiting from the compositional elegance of the Credit Lyonnais trilogy: There will usually be a range of choices (no matter how limited) and directors should probably be permitted to take the middle one.

Perhaps the most important facet of the efficiency paradigm is that, like the event/condition paradigm, priority plays a central but inchoate role. All three maximization orientations presume that creditors are, or would become, the residual claimants against the distressed corporation, displacing shareholders. Yet this will be true largely by virtue of the received model of priority: creditors first, then shareholders. Creditors can become the residual claimants only if one believes that their claims to the distressed firm's assets are prior to those of presumptively junior classes like shareholders.

This, then, frames the question: Why should priority matter to duty? Extracontractual duties could just as easily arise for other reasons, such as those that appear to inform duty in the shareholder context--volition, cognition, and exit. Or, we could say that duty is merely a windfall to creditors, whose expectations should be fully protected by contract, creditors' remedies, or accepted commercial conceits (such as generalized notions of priority). Why

175. A good recent discussion of the problems with rational choice theory appears in W. Bradley Wendel, Mixed Signals: Rational-Choice Theories of Social Norms and the Pragmatics of Explanation, 77 IND. L.J. 1 (2002).

176. See Oliver E. Williamson, Transaction Cost Economics, in 1 HANDBOOK OF INDUSTRIAL ORGANIZATION 135, 138-40 (Richard Schmalensee \& Robert D. Willig eds., 1989). The term "bounded rationality" comes from HERBERT A. SIMON, MODELS OF MAN 196 (1957).

177. See, e.g., Kent Greenfield \& John E. Nilsson, Gradgrind's Education: Using Dickens and Aristotle to Understand (and Replace?) the Business Judgment Rule, 63 BROOK. L. REV. 799 passim (1997). 
should residual claimant status bring with it the baggage of duty, especially since, as discussed in the next section, priority would appear to serve different purposes than duty, and to have its own doctrinal problems?

\section{PROBLEMS WITH PRIORITY}

The prior part suggested that the major explanations of directorial duties to creditors turn on a particular, although unstated, construction of priority in right of payment: Duty runs to creditors of the distressed firm because they - not shareholders-are residual claimants. This part assesses problems which render priority as doctrine an incomplete basis for understanding directorial duties.

\section{A. Priority as a Distributional Doctrine}

In its essence, priority is a distributional doctrine. As such, it addresses different problems than does duty. Modern concerns about priority appear to have developed as a response to perceived abuses in the railroad reorganizations of the late nineteenth and early twentieth centuries, when senior creditors and shareholders often froze out general unsecured creditors. ${ }^{178}$ Because unsecured creditors were to be paid in full before shareholders on a general theory of priority, permitting shareholders to receive or retain property in the face of an unsecured creditor shortfall violated what has come to be known as the absolute priority rule (the APR). ${ }^{179}$

The contours and meaning of the APR have received considerable academic attention. ${ }^{180}$ Although said to be "universal," rule has also been criticized in the reorganization context as being none of those three things (absolute, about priority, or a rule). Thus, the bankruptcy reorganization process is replete with exceptions to absolute priority. The doctrine of necessity, for example, is frequently invoked in bankruptcy cases to permit certain creditors to obtain priority over others with whom they should share ratably. ${ }^{182}$ Similarly, Bankruptcy Code $\$ 364(d)$ permits the

178. See Douglas G. Baird \& Thomas H. Jackson, Bargaining After the Fall and the Contours of the Absolute Priority Rule, 55 U. CHI. L. REV. 738, 739-40 (1988).

179. The term was apparently coined by James C. Bonbright and Milton M. Bergerman. See James C. Bonbright \& Milton M. Bergerman, Two Rival Theories of Priority Rights of Security Holders in a Corporate Reorganization, 28 COLUM. L. REV. 127, 130 (1928).

180. Much of our understanding about the absolute priority rule (APR) comes from the famous essay by Walter Blum. See generally Walter J. Blum, The Law and Language of Corporate Reorganizations, 17 U. CHI. L. REV. 565 (1950).

181. See Wewoka Petroleum Corp. v. Gilmore, 319 P.2d 285, 289 (Okla. 1957).

182. See Russell A. Eisenberg \& Frances F. Gecker, The Doctrine of Necessity and Its Parameters, 73 MARQ. L. REv. 1 (1989); see also In re CoServ, L.L.C., 273 B.R. 487, $492-93$ (Bankr. N.D. Tex. 
bankruptcy court to authorize the debtor to borrow money secured by a senior or equal lien on property of the estate that is subject to a valid lien. ${ }^{183}$ Perhaps most important for our purposes, plans of corporate reorganization under Chapter 11 of the United States Bankruptcy Code ${ }^{184}$ often deviate from the APR. ${ }^{185}$

A reorganization plan is the judicially approved contract between the debtor and its various stakeholders. These plans often deviate from absolute priority by permitting shareholders to retain an interest in the reorganized debtor, even though some dissenting creditors are not paid in full. Sometimes this occurs because enough creditors effectively agree to permit equity holders to retain a stake in the company. Other times, it happens by virtue of what is somewhat euphemistically referred to as the "new value exception"

2002); In re Just for Feet, Inc., 242 B.R. 821, 826 (D. Del. 1999); In re NVR L.P., 147 B.R. 126, $127-$ 28 (Bankr. E.D. Va. 1992); In re Fin. News Network Inc., 134 B.R. 732, 735-36 (Bankr. S.D.N.Y. 1991); In re Eagle-Picher Industries, Inc., 124 B.R. 1021, 1023 (Bankr. S.D. Ohio 1991). Those who invoke it do not always succeed. See Capital Factors, Inc. v. Kmart Corp., 291 B.R. 818, 825 (N.D.Ill. 2003) (reversing bankruptcy court orders approving payments made under doctrine of necessity).

183. Section 364(d) provides as follows

(d)(1) The court, after notice and a hearing, may authorize the obtaining of credit or the incurring of debt secured by a senior or equal lien on property of the estate that is subject to a lien only if-

(A) the trustee is unable to obtain such credit otherwise; and

(B) there is adequate protection of the interest of the holder of the lien on the property of the estate on which such senior or equal lien is proposed to be granted.

(2) In any hearing under this subsection, the trustee has the burden of proof on the issue of adequate protection.

11 U.S.C. $\$ 364$ (d) (2000).

184. See 11 U.S.C. $\$ \$ 101-1330(2000)$.

185. See JULIAN R. FRANKS \& WALTER N. TOROUS, HOW FIRMS FARE IN WORKOUTS AND CHAPTER 11 REORGANizATIONS 15 (John E. Anderson Grad. Sch. of Mgmt. at UCLA No. 1-91, 1991) ("[A]ll firms in our Chapter 11 sample experience deviations from the rules of absolute priority."); Allan C. Eberhart et al., Security Pricing and Deviations from the Absolute Priority Rule in Bankruptcy Proceedings, 45 J. FIN. 1457, 1458 (1990) (finding deviations from the APR represent 7.6 percent of the total amount awarded to all claimants); Julian R. Franks \& Walter N. Torous, An Empirical Investigation of U.S. Firms in Reorganization, 44 J. FiN. 747, 754-55 (1989); Jerome R. Kerkman, The Debtor in Full Control: A Case for Adoption of the Trustee System, 70 MARQ. L. REV. 159, 160-65 (1987); Lynn M. LoPucki \& William C. Whitford, Bargaining over Equity's Share in the Bankruptcy Reorganization of Large, Publicly Held Companies, 139 U. PA. L. REV. 125, $141-42,166$ (1990) [hereinafter LoPucki \& Whitford, Bargaining] (reporting deviations from the APR in favor of equity in 30 of 43 cases (67 percent)). See generally EXECUTIVE OFFICE FOR U.S.

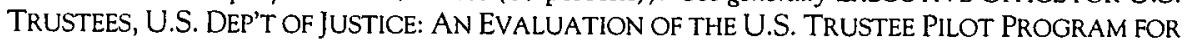
BANKR. ADMIN. 39-87 (1983); Lynn M. LoPucki, The Debtor in Full Control-Systems Failure Under Chapter 11 of the Bankruptcy Code? (Pts. 1 \& 2), 57 AM. BANKR. L.J. 99 (1983) (reporting on an empirical study focusing on the effects of the 1978 changes in bankruptcy reorganization processes); Lawrence A. Weiss, Bankruptcy Resolution: Direct Costs and Violation of Priority of Claims, 27 J. FIN. ECON. 285, 294 (1990) (finding priority rules violated in 78 percent of the twenty-four Chapter 11 reorganizations studied). 
to the APR, whereby pre-bankruptcy shareholders can repurchase their interest in the debtor by injecting some new value into it. ${ }^{186}$

If priority plays an attenuated role in many reorganizations, it is curious that priority should control the vector of duty prior to bankruptcy. First, because priority is a distributional doctrine with perhaps more in terrorem than actual force, it may not have a great deal of meaning to directors seeking to cure a distressed firm. Indeed, a key assumption of the opinion in Credit Lyomnais - and probably of most corporate directors-is that the firm will remain a going concern; directors will not distribute anything, to creditors or anyone else, except in the ordinary course, once the firm is returned to solvency. Priority is properly viewed as a concept relegated to liquidation or bankruptcy reorganization. To consider priority at all may be an admission of defeat to many directors.

Second, even if directors believed that their duties should follow priority, it is not clear that the patterns of priority are sufficiently predictable to guide them in their decisionmaking. Put another way, because the APR is so often honored in the breach, it may be difficult for directors, ex ante, to know how priority rules would apply to corporate stakeholders ex post. Perhaps the key point here is that, at the moment that it matters most-the "vicinity of insolvency"-it will usually be difficult, if not impossible, to know whether the corporation will be able to reorganize, or whether it will have

186. The "new value exception" has permitted courts to approve a plan as "fair and equitable," notwithstanding that old equity would retain some or all of their equity interests, and that creditors would not be paid in full under the plan if the old equity made a contribution to the reorganized debtor "in money or in money's worth" reasonably equivalent to the equity interests retained under the plan. The exception appears to derive from Case v. Los Angeles Lumber Products, Co., 308 U.S. 106, 122 (1939). Courts have debated whether the new value exception survived the enactment of the Bankruptcy Code, because the APR was included in the stature without a statutory new value exception. Compare Bonner Mall P'ship v. U.S. Bancorp Mortgage Co. (In re Bonner Mall P'ship), 2 F.3d 899, 907-17 (9th Cir. 1993) (holding that the new value exception survived enactment of the Bankruptcy Code), motion to vacate denied and case dismissed as moot, 513 U.S. 18 (1994), and Teamsters Nat'l Freight Indus. Negotiating Comm. v. U.S. Truck Co. (In re U.S. Truck Co.), 800 F. 2d 581, 588 (6th Cir. 1986), with In re Woodbrook Assocs., 19 F.3d $312,319-20$ (7th Cir. 1994) (reserving ruling on the viability of the new value exception).

Although the Supreme Court dodged the opportunity to address the matter in Norwest Bank Worthington v. Ahlers, 485 U.S. 197 (1988), it may have pared the new value exception back recently in Bank of American National Trust 8 Savings Association v. 203 N. LaSalle St. Partmership, 526 U.S. 434,458 n.28 (1999). While the Court did not fully explain the state of the new value exception in La Salle, the Court did decide that the plan proposed by the debtor in that case could not satisfy the APR because of the absence of a market-based valuation mechanism. Id. at 458. Nevertheless, the new value exception may persist, especially in cases involving smaller or privately held corporate debtors, or where valuation has been determined by some kind of market mechanism. See Hieu T. Hoang, Comment, The New Value Exception to the Absolute Priority Rule After In te 203 N. LaSalle Street Partnership: What Should Bankruptcy Courts Do, and How Can Congress Help?, 149 U. PA. L. REV. 581, 596-612 (2000). 
to liquidate. ${ }^{187}$ Thus, in that moment, directors may have no idea to whom their duties run because the shadow cast by priority-and therefore, the vector of duty that apparently follows it-is simply too obscure to form the basis of any intelligent judgment. ${ }^{188}$

\section{B. Priority and Valuation}

These problems with priority are exacerbated by the fact that firm valuation is a moving target, both because solvency is a malleable concept, and because increasingly complex corporate assets and obligations intentionally obscure or manipulate priority.

\section{Solvency as a Moving Target}

As a distributional doctrine, priority must have some important link to solvency. The problem, however, is that absent an actual liquidation of all of the corporation's assets, it will often be difficult to know the true value of the large corporation, and therefore to know who the real residual claimants are. Valuing a large, complex business for reorganization purposes is difficult and expensive-“"'a guess compounded by an estimate." 189 Valuation will be critical to any nonconsensual reorganization plan, and rough estimates of

187. Indeed, the distinction between liquidation and reorganization is not especially stark. Corporate debtors frequently liquidate some-or even most-of their assets in the process of reorganization. Does this mean that they have or have not reorganized? See Lynn M. LoPucki \& William C. Whitford, Patterns in the Bankruptcy Reorganization of Large, Publicly Held Companies, 78 CORNELL L. REV. 597, 605 (1993) ("Bankruptcy analysts often characterize particular bankruptcy cases as reorganizations or liquidations. This distinction is of limited usefulness with respect to large, publicly held companies. Nearly all of them liquidate some assets and a few liquidate all assets.") (footnote omitted).

188. Problems with priority in the bankruptcy context are often made worse by the rules on the creation of stakeholder classes for purposes of voting on (and receiving distributions under) the plan. Sections 1122 and 1123 of the Bankruptcy Code give the plan proponent wide range to create classes of stakeholders in the debtor. 11 U.S.C. $\$ \$ 1122-1123(2000)$. The only limit is that, to be classified together, claims or interests must be substantially similar. Plan proponents can obtain significant strategic advantages by classifying stakeholders creatively, although they are prohibited from gerrymandering the classification of claims in order to obtain a favorable plan vote. See John Hancock Mutual Life Ins. Co. v. Route 37 Bus. Park Assocs., 987 F.2d 154, 159, 161 (3d Cir. 1993); Phoenix Mutual Life Ins. Co. v. Greystone III Joint Venture (In re Greystone III Joint Venture), 948 F.2d 134, 139 (5th Cir.1991), cert. denied, 506 U.S. 821, 822 (1992); see also G. Eric Brunstad, Jr. \& Mike Sigal, Competitive Choice Theory and the Unresolved Doctrines of Classification and Unfair Discrimination in Business Reorganizations Under the Bankruptcy Code, 55 BUS. LAW. 1 (1999).

189. Peter F. Coogan, Confirmation of a Plan Under the Bankruptcy Code, 32 CASE W. RES. L. REV. 301, 313 n.2 (1982) (citing statement in H.R. REP. No. 95-598, at 225 (1978), reprinted in 1978 U.S.C.C.A.N. 6181, 6184). 
value are routinely offered in all reorganizations, for a variety of purposes. ${ }^{190}$ Yet, for the most part, consent displaces valuation of the corporation. With sufficient support from creditors and shareholders, a plan of reorganization may be approved even over the objections of a certain number of holdouts. ${ }^{191}$

The discussion of valuation and duty is usually organized around the difficulty of determining when a corporation is insolvent, a problem Credit Lyonnais made materially more difficult by suggesting that duties shift (or expand) well before bankruptcy, once the corporation is "in the vicinity" of insolvency, an uncertain point on the financial map. ${ }^{192}$ It is, of course, clear that solvency, like valuation, is an exceedingly complex and difficult determination to make. ${ }^{193}$

Lawyers generally recognize two different-sometimes inconsistent-tests for solvency. On the one hand, the equitable test treats a firm as insolvent when it cannot pay its debts as they come due in the ordinary course. ${ }^{1.4}$ This test cannot be taken too literally, since many corporations fail for any number of reasons to pay some debts in the ordinary course. ${ }^{195}$ On the other hand, there is the bankruptcy test, under which a corporate debtor is insolvent when the sum of its debts exceeds the fair value of its assets. ${ }^{196}$

The bankruptcy test of solvency presents its own problems. First, it applies only to the extent that a bankruptcy case (or other insolvency proceeding) has commenced. Second, and more important, it is becoming increasingly difficult to ascribe stable valuations to many important, complex

190. For example, plans of reorganization are usually supported by a liquidation analysis, whereby the plan proponent purports to show that all dissenting stakeholders are treated better under the plan than they would be in a Chapter 7 liquidation of the debtor, thus satisfying the best interest of creditors' test. See In re PWS Holding Corp., 228 F.3d 224, 250 (3d Cir. 2000) (rejecting a "best interests of creditors" challenge under $\$ 1129(\mathrm{a})(7)$ because appellant "failed to challenge the Debtors' liquidation analysis."). But it would be difficult to claim that these analyses actually define the value of the debtor, especially when it is reorganized. As LoPucki and Whitford suggest,

$[\mathrm{H}]$ olders of underwater claims and interests... derive at least part of their bargaining leverage in plan negotiations from their ability to dispute the value of the assets continued in their current use, and therefore the value of the reorganization securities that would be issued if the company were reorganized rather than liquidated. Even if market values are available, parties in interest are permitted to argue that they are incorrect.

LoPucki \& Whitford, supra note 109, at 685.

191. See 11 U.S.C. $\$ \$ 1126$ (c)-(d), 1129(b) (2000).

192. See supra notes 103, 119.

193. See, e.g., Rao, supra note 2, at 62 ("The terms 'financial distress' and 'insolvency' are broad and ambiguous.").

194. See, e.g., REV. MODEL BUS. CORP. ACT $\$ 6.40$ (c)(1) (1991).

195. See, e.g., Nahman v. Jacks (In re Jacks), 243 B.R. 385, 390 (Bankr. C.D. Cal. 1999) (failure to pay a single creditor is insufficient to show insolvency and thus trigger a fiduciary duty to creditors), aff d in part, rev'd in part, 266 B.R. 728 (9th Cir. 2001).

196. 11 U.S.C. $\$ 101(32)(A)(2000)$. 
assets and liabilities. There can be wide yet legitimate differences of opinion on the value of common intangible assets, such as intellectual property and data. ${ }^{197}$ To the extent that debtors hold in their portfolios complex financial instruments, ${ }^{198}$ such as derivatives, valuations will be even more difficult. ${ }^{199}$ The problem of retroactive insolvency-the result of downward restatements or corrections of prior financial statements-compounds these problems, because it means companies may have been insolvent on a book basis long before directors knew that the corporation was in distress. ${ }^{200}$ Directors of Enron and WorldCom, among others, have recently learned this the hard way.

\section{The Debt/Equity Paradigm}

In the same way that solvency may be difficult to determine, the rights of various corporate claimants may also be moving targets. This is because it is often difficult to tell whether a corporate obligation is debt, equity, or some combination of the two. Corporations frequently issue paper that exhibits features of both debt and equity. ${ }^{201}$ Venture capitalists, among others, often seek

197. See generally Jonathan C. Lipson, Financing Information Technologies: Faimess and Function, 2001 WIS. L. REV. 1067 (discussing valuations of intangible property).

198. I use the term "instrument" loosely. These sorts of obligations will usually not be negotiable instruments under U.C.C. Article 3 because, among other reasons, they are not a "promise or order to pay a fixed amount of money." See U.C.C. \$ 3-104(a) (2001).

199. Jerry W. Markham, "Confederate Bonds," "General Custer," and the Regulation of Derivative Financial Instruments, 25 SETON HALL L. REV. 1, 29-31 (1994) (discussing valuation problems with derivatives). A leading example of the volatility of derivatives is Long-Term Capital Group. See Carol J. Loomis, A House Built on Sand, FORTUNE, Oct. 26, 1998, at 110. Long-Term Capital made highly leveraged bets on the historical interest rate spread between risky bonds and U.S. Treasury securities. It ran into trouble when it lost these bets due to the apparently unanticipated implosion of Russia's financial markets. Investors in Russian markets pulled out and invested instead in U.S. Treasury securities. As the value of Treasury securities went up, LongTerm's value declined. See Steven Lipin et al., Bailout Blues: How a Big Hedge Fund Marketed Its Expertise and Shrouded Its Risks, WALL ST. J., Sept. 25, 1998, at A1.

200. See Rao, supra note 2, at 63-64, 67 ("[O]nce a firm seeks the protection of bankruptcy, its balance sheet may be retroactively restated through write-offs and write-downs of assets to show that it was insolvent at some point before the filing. This retroactive restatement ... may create serious complications for both the creditors and the agents [e.g., directors] of the firm."); Barondes, supra note 2 , at 72 .

201. See, e.g., Ellen Engel et al., Debt-Equity Hybrid Securities, 37 J. ACCT. REs. 249 (1999) (studying Monthly Income Preferred Shares (MIPS) and other securities that were treated as debt for tax purposes, but not for rating agency and accounting purposes); Louis S. Freeman \& Matthew A. Stevens, Tax Consequences of Business and Investment Driven Uses of Financial Products, in TAX STRATEGIES FOR CORPORATE ACQUISITIONS, DISPOSITIONS, SPIN-OFFS, JOINT VENTURES, FinanCINGS, REORGanizations \& RESTRUCTURINGS 2001, 9 (PLI Tax Law and Estate Planning Course Handbook Series No. J0-004I, 2001); Joseph A. Grundfest, The Limited Future of Unlimited Liability: A Capital Markets Perspective, 102 YALE L.J. 387, 405-08 (1992) (discussing "exotic hybrid debt-equity instruments"); Katherine Pratt, The Debt-Equity Distinction in a Second-Best World, 53 VAND. L. REV. 1055, 1080-88 (2000) (discussing debt-equity hybrids). 
and obtain preferred stock that may convert to subordinated debt of the issuer under certain circumstances. ${ }^{202}$ Similarly, redemption debt-a corporation's purchase of its shares with debt issued to the selling shareholder-frequently results in ambiguous treatment as a matter of priority. ${ }^{203}$ And, once a firm is in distress, speculators will often acquire creditors' claims against the corporation believing that these claims will convert to equity in the reorganized debtor. ${ }^{204}$

Modern corporate finance theory may share, and perhaps heighten, these ambiguities. The Modigliani/Miller theorem, for example, teaches that in a perfect market investors should be indifferent to firm capital structure (priority) because the cost of capital invested in one form will counteract the cost of capital in another form. ${ }^{205}$ The Modigliani/Miller theory is often the starting point for analyzing the puzzle of priority in a slightly different but related

202. See generally Lawrence E. Mitchell, The Puzzling Paradox of Preferred Stock (And Why We Should Care About It), 51 Bus. LAw. 443 (1996); Robert B. Robbins \& Barton Clark, The Board's Fiduciary Duty to Preferred Stockholders, 7 INSIGHTS, Nov. 1993, at 18.

203. Most courts will treat the redemption debt as a junior obligation to make a distribution on stock, rather than as a senior claim entitled to priority with other creditors. See, e.g., Weisman v. Goss (In re Hawaii Corp.), 694 F.2d 179 (9th Cir. 1982); Robinson v. Wangemann, 75 F.2d 756 (5th Cir. 1935); Ferrari v. Family Mut. Sav. Bank (In re New Era Packaging, Inc.), 186 B.R. 329 (Bankr. D. Mass. 1995); In re SPM Mfg. Corp., 163 B.R. 411 (Bankr. D. Mass. 1994); In re Dino \& Artie's Automatic Transmission Co., 68 B.R. 264 (Bankr. S.D.N.Y. 1986); Liebowitz v. Columbia Packing Co., 56 B.R. 222 (D. Mass. 1985), aff d per curiam, 802 F.2d 439 (1st Cir. 1986). As these courts see it, to give the redemption claim parity with the claims of other creditors offends the priority which creditors should enjoy over stockholders in bankruptcy. E.g., Wangemann, 75 F.2d at 757-58. Other courts believe subordination requires misconduct on the part of the claimant. See In re Stem-SlegmanPrins Co., 86 B.R. 994, 1000 (Bankr. W.D. Mo. 1988). Others examine state corporate law. If there is a statute which prohibits the corporation from paying for its own shares out of capital, these courts subordinate the redemption claim to other claims. See, e.g., La Grand Steel Products Co. v. Goldberg (In re Poole, McGonigle \& Dick, Inc.), 796 F.2d 318, 323 (9th Cir. 1986), amended by, 804 F.2d 576 (9th Cir. 1986) (applying statute prohibiting purchase or payment for corporation's own shares when purchase or payment would make it insolvent); Gold v. Lippman (In re Flying Mailmen Service, Inc.), 539 F.2d 866, 869 (2d Cir. 1976) (applying statute permitting purchase of own shares "except when currently the corporation is insolvent or would thereby be made insolvent"); McConnell v. Estate of W.H. Butler, 402 F.2d 362 (9th Cir. 1968) (applying statute permitting "payment" to extent of current earned surplus); In re Trimble Co., 339 F.2d 838 (3d Cir. 1964), appeal after remand, 479 F.2d 103 (3d Cir. 1973) (construing statute unspecific on time of purchase to apply to time of payment). See also Mountain State Steel Foundries, Inc. v. Comm'r, 284 F.2d 737, 745 n.3 (4th Cir. 1960) (applying statute permitting corporation to "use its funds" for purchase of its own shares when this would not cause impairment of capital; court held interest deductions permissible so long as capital not impaired).

204. See William W. Bratton, Jr., The Economics and Jurisprudence of Convertible Bonds, 1984 WIS. L. REV. 667, 735-39; Jeremy I. Bulow et al., Distinguishing Debt from Equity in the Junk Bond Era, in Debt, TAXES, AND CORPORATE Restructuring 135, 135 (John B. Shoven \& Joel Waldfogel eds., 1990) (characterizing junk bonds as "equity in drag").

205. Franco Modigliani \& Merton H. Miller, The Cost of Capital, Corporation Finance and the Theory of Investment, 48 AM. ECON. REV. 261, 267-70 (1958). 
context, personal property secured financing. ${ }^{206}$ Like Modigliani/Miller, the Capital Asset Pricing Model discussed above also suggests that priority may be of limited use. ${ }^{207}$

These problems with priority do not, of course, lead inexorably to the conclusion that priority doctrine should be abandoned. Priority is a helpful, if fuzzy, way to order claims against a corporation. Rather, the problem is that it is an incomplete basis for determining the vector of duty that arises upon firm distress. How incomplete is made clear in the next part, where the deeper, and better, bases for directorial duties are set forth.

\section{VOLITION, COGNITION, AND EXIT}

Part I of this paper described in general terms the two major academic approaches to duty: the contractarian and the anticontractarian. As discussed above, contractarians tend to argue that duty as such is neither meaningful nor useful in the corporate context. Rather, contract, broadly understood, provides a far better positive and normative explanation of what is often called duty. The anticontractarians live up to their name, and retort that certain obligations in the corporate context-for example, loyalty-cannot be contracted away.

This debate has persisted for many years and shows no strong evidence of resolution. ${ }^{208}$ Rather, like the combatants in Vietnam, both sides appear to have declared victory and moved on to other endeavors. This is unfortunate because beneath the surface, one sees grounds far better than priority for recognizing (or not recognizing) duties to creditors: power imbalances expressed as disparities of volition, cognition, and exit.

\section{A. Power and Duty}

To be sure, contractarians and anticontractarians have different views about the relative significance of these three factors. Anticontractarians tend

206. See, e.g., Claire A. Hill, Is Secured Debt Efficient?, 80 TEX. L. REV. 1117, 1118 n.6 (2002) (observing that if one accepts the Modigliani/Miller theorem, "the task becomes identifying the realworld frictions and costs that make complex and costly transaction structures such as secured debt worthwhile."). Modigliani/Miller is not without its critics. Paul Milgrom and John Roberts, for example, observe that, like other economic theories, it may be too elegant to be instructive about the real world. See PAUl MILGROM \& JOHN ROBERTS, ECONOMICS, ORGANIZATION AND MANAGEMENT 504 (1992) ("Changing the financing of the firm changes incentives, and the resulting real changes in behavior affect the returns that are generated.").

207. See discussion supra Part I.B.2.a.

208. It may, however, change its appearance. See, e.g., Richard H. McAdams, Signaling Discount Rates: Law, Noms, and Economic Methodology, 110 YALE L.J. 625, 625-26 (2001) (describing law and social norms as a "new trend" in law and economics). 
to be far more susceptible than contractarians to arguments that disparities in volition and cognition matter. Contractarians, by contrast, would appear more concerned about the power imbalance reflected in a relationship for which the market provides no exit.

Anticontractarian concerns about volition and cognition are perhaps most eloquently expressed in the work of Victor Brudney. ${ }^{209}$ He has, for example, argued that widely dispersed shareholders of a publicly held company usually lack the volition to negotiate meaningful charter or other provisions with corporate directors and officers. ${ }^{210}$ Even if they have the right to attend and vote at a shareholders' meeting, the matters for consideration are usually not the ones of significance to the shareholders. In fact, many important corporate transactions can occur without any shareholder input whatsoever, a state of affairs that has occasionally led to admonition from the Delaware Chancery Court. ${ }^{211}$ "At most," Brudney writes,

[S]tockholders vote for directors, and they must rely on directors to act for them to hire and renew the "contracts" of managers. In that process, it is plain that stockholders have little knowledge and less choice in selection, retention, or determination of the terms of employment of either directors or executives. ${ }^{212}$

Nor do widely dispersed shareholders enjoy meaningful levels of cognition. ${ }^{213}$ The public issuance of securities under the $1933 \mathrm{Act}^{214}$ and the registration of companies under the $1934 \mathrm{Act}^{215}$ may, in theory, produce

209. See, e.g., Brudney, Corporate Governance, supra note 37 , at 1406 , stating that:

It is erroneous to use the term "contract" to describe dispersed stockholders' relation to the original owner or to corporate management, if by doing so the user assimilates the assumptions about parties' volition and cognition in conventionally bargained and closed buy-sell contracts to the circumstances that attend the connection between purchase or sale of stock and the long term, open ended contracts between management and its corporation. Id. (footnotes omitted).

210. Id. at 1406, 1412 ("Scattered stockholders cannot, and do not, negotiate with owners who go public (or with management-either executives or directors) over hiring managers, over the terms of their employment, or over their retention.").

211. See, e.g., City Capital Assocs. Ltd. P'ship v. Interco, Inc., 551 A.2d 787, 797 (Del. Ch. 1988) (discussing threats to the voluntariness of shareholders' choices); AC Acquisitions Corp. v. Anderson, Clayton \& Co., 519 A.2d 103, 114-15 (Del. Ch. 1986) (holding that the company had made a coercive "self-tender" that could "deprive shareholders of an option that may as likely as not be the more attractive alternative"); Lacos Land Co. v. Arden Group, Inc., 517 A.2d 271, 27576 (Del. Ch. 1986) (holding that "the proxy statement upon which the vote was solicited Ifrom shareholders] was materially misleading" and that the shareholders were coerced into acceptance); see also Eisenberg v. Chicago Milwaukee Corp., 537 A.2d 1051, 1063 (Del. Ch. 1987) (enjoining a stock issuer's self-tender offer due to its coercive nature).

212. Brudney, Corporate Governance, supra note 37, at 1412-13.

213. See id. at 1405.

214. 15 U.S.C. $\$ \$ 77 a-77$ aa (2002 Supp.).

215. 15 U.S.C. $\$ \S 78 \mathrm{a}$ et seq. (2002 Supp.). 
significant quantities of information about the securities and the company, respectively. But even if the information is accurate, it is not at all clear that it will be meaningful to individual shareholders. The boundedness of rationality means that even diligent shareholders will have a limited capacity to understand the functioning of the company. In any case, public shareholders tend to discount the probability of future unpleasantries. ${ }^{216}$ Moreover, investing significant time and expense to gather and process such information may be economically irrational. ${ }^{217}$ In any event, public shareholders will generally have far less information than will the directors and officers who make the important corporate decisions. For this reason, disparities in access to information and the ability to use it would appear to be central to the recognition of a duty. ${ }^{218}$ John Coffee, for example, argues that information production should be the guiding principle for courts trying to resolve disputes about duty. ${ }^{219}$

Concerns about volition and cognition recognize the normative challenges posed by certain kinds of power imbalances. Corporate insiders have greater power on this account because they-and not widely dispersed public shareholders-control most corporate decisions and information.

Although we tend to assume that contractarians tolerate no talk of duty, there is on that approach one power imbalance that may require the intercession of duty: when there is no meaningful ability to exit the corporate relationship. Thus, Easterbrook and Fischel, perhaps the most ardent of contractarians, grudgingly acknowledge that "persons counseling purchases of ... illiquid investments owe stronger duties to their clients than persons counseling purchases of stock traded over the counter, and persons selling stock traded on a national exchange owe almost no duties (beyond avoiding churning). This is indeed the pattern.,220 In her response to the Easterbrook and Fischel piece, Roberta Romano observes that the availability of exit via a secondary market may be critical to the strength of any given set of duties: "The

216. See, e.g., Eisenberg, supra note 38, at 1465 ("“[E]vidence tends to confirm[ ] there is a tendency to underestimate uncertainties.") (quoting Kenneth Arrow, Risk Perception in Psychology and Economics, 20 ECON. INQUIRY 1, 5 (1982)).

217. See, e.g., Brudney, Contract and Duty, supra note 42, at $623 \mathrm{n} .76$ ("Rational apathy precludes dispersed stockholders from acquiring the relevant information that the model contracting party would seek.").

218. See, e.g., Frankel, Fiduciary Duties, supra note 38, at 1244 ("[I]n fiduciary law, the duty of loyalty is grounded in asymmetric information.").

219. Coffee, supra note 37, at 1619 n.1 (courts should "seek[ ] to create ex ante incentives for the disclosure of private information.").

220. Easterbrook \& Fischel, Contract and Fiduciary Duty, supra note 31, at 437. 
relations identified as imposing stricter duties are those in which market forces, in one or both dimensions, are not robust. ${ }^{\prime 221}$

Thus, while they may not agree that the traditional duties of loyalty and care exist independent of contract, contractarians would seem to support the notion that exclusion from secondary markets-exit-is grounds to supplement the contractual relationship of the parties. Here too, power imbalance can explain the extracontractual obligation (whether or not called duty). Being trapped in an economic relationship implies a certain kind of vulnerability to the predations of the stronger party.

The rhetoric of vulnerability also appears central to a recent article by Margaret Blair and Lynn Stout which is, itself, perhaps the purest exploration of the relationship between power and duty in the corporate context. ${ }^{222}$ Blair and Stout argue that "what can make a norms-based theory of corporate law both powerful and persuasive... is the empirical phenomenon of trust behavior. ${ }^{223}$ Blair and Stout start from the position that "trust" describes a relationship where one party (the "trusting" actor) "make[s] herself vulnerable to the trusted actor in circumstances in which the trusted actor could benefit from taking advantage of the trusting actor's vulnerability. ${ }^{1224}$ They draw their picture of trust from models developed by organizational and social theorists, who have long argued that the rational-actor model underpinning most contractarian thought is seriously misguided. ${ }^{225}$ Rather, they argue, trust is a learned behavior highly dependent on social context. It can be-and often is-a norm that permeates behavior in the corporate context. ${ }^{226}$ Implicit in the vulnerability of the trusting party is a recognition that the imbalance of power, however construed, is grounds for imposing a duty on the trusted party.

221. Roberta Romano, Comment on Easterbrook and Fischel, "Contract and Fiduciary Duty," $36 \mathrm{~J}$. L. \& ECON. 447, 449 (1993). Perhaps reflecting a similar sentiment, Royce Barondes has recognized the disadvantages experienced by trade creditors, where the market for their claims is viewed as inefficient. See Barondes, supra note 2, at 90-98.

222. See Blair \& Stout, Trust, supra note 39.

223. Id. at 1794 .

224. Id. at 1746. The full description of trust is thus:

First, trust involves at least two actors-the actor who trusts and the actor who is trusted.

Second, the trusting actor must deliberately make herself vulnerable to the trusted actor in circumstances in which the trusted actor could benefit from taking advantage of the trusting actor's vulnerability. Third, the trusting actor must make herself vulnerable in the belief or expectation that the trusted actor will in fact behave "trustworthily" - that is, refrain from exploiting the trusting actor's vulnerability. Trust and trustworthiness accordingly are closely linked, with the former depending upon an expectation of the latter. Id. at $1745-46$.

225. Id. at 1750-57, nn. 51-53,1764 ("[A] behavioral model of trust that relies solely on calculative self-interest is likely to miss much if not most of the phenomenon it attempts to describe.").

226. Id. at $1766-69$. 
Concerns about imbalances of power also play a central role in two bodies of academic discourse related to, but distinct from, the discussion about duty in the corporate context. First, there is a rich literature on the fate of "non-adjusting creditors" in the context of secured personal property finance. ${ }^{227}$ In these discussions, nonadjusting (or weakly adjusting) creditors are those creditors who-like the low VCE creditors discussed in this Article-do not choose to extend credit to the corporation, and so cannot through pricing or other market mechanisms adjust their rights against the debtor, even if the debtor fully encumbers its assets.

Like the discussion about directorial duty, the debate about the propriety of giving a single secured creditor full priority in the debtor's assets, to the (alleged) detriment of nonadjusting creditors rests on varying levels of concern about power imbalances. Proponents of full priority (who often resemble-and may be-contractarians) argue that all parties (even nonadjusting creditors) are better off if the debtor is ex ante permitted to grant full priority in its assets to a single lender. ${ }^{228}$ The lender would presumably extend credit sufficient to justify any costs borne by nonadjusting creditors. Because, on the full priority view, debtors have the power conferred by contract and property law to convey all of their assets, they have the power to encumber them fully. ${ }^{229}$ We should not be unduly sympathetic to nonadjusting creditors, even though they may be in weaker positions, ${ }^{230}$ because this would weaken "bedrock" institutions of property and contract, ${ }^{231}$ and may lead to economic inefficiency.

Opponents of full priority, by contrast, appear to have a temperament similar to anticontractarians, and argue that full priority simply transfers costs to those in the weakest position to protect themselves-nonadjusting creditors. ${ }^{232}$ As Lynn LoPucki has argued, "The ability to victimize involuntary

227. Symposium issues of the Comell Law Review and the Virginia Law Review offer revealing glimpses into this debate. See Symposium, The Priority of Secured Debt, 82 CORNELL L. REV. 1279 (1997); Symposium on the Revision of Article 9 of the Uniform Commercial Code, 80 VA. L. REV. 1783 (1994). A good recent treatment of the issue appears in Hill, supra note 206. The term "nonadjusting creditors" comes from Lucian Arye Bebchuk \& Jesse M. Fried, The Uneasy Case for the Priority of Secured Claims in Bankruptcy, 105 YALE L.J. 857, 864 (1996).

228. See, e.g., Steven L. Schwarcz, The Easy Case for the Prionity of Secured Claims in Bankruptcy, 47 DUKE L.J. 425 (1997).

229. Steven L. Harris \& Charles W. Mooney, Jr., A Property-Based Theory of Security Interests: Taking Debtors' Choices Seriously, 80 VA. L. REV. 2021, 2034 (1994).

230. See id. at 2045 (arguing that those sympathetic to nonadjusting creditors "are uneasy about the apparent power and influence that secured creditors may wield over a debtor's fortunes").

231. See id. at 2047-48.

232. See, e.g., Lynn M. LoPucki, The Unsecured Creditor's Bargain, 80 VA. L. REV. 1887 (1994). 
creditors may in significant part explain 'why secured credit is such a widespread phenomenon.",233

The second related discussion emanates from the proposal, often associated with Henry Hannsman and Reinier Kraakman, that shareholders should have unlimited liability for corporate torts. ${ }^{234}$ Their principal argument for abrogating limited shareholder liability is economic: Limited shareholder liability causes corporations, and by inference their shareholders, to take something resembling path 1 , and to overinvest in excessively risky activities whose costs are externalized-borne by others who may not be compensated for loss when the risks are realized. ${ }^{235} \mathrm{~A}$ minor motif here is the recognition that tort creditors are involuntary creditors and so, on my account, would lack volition. ${ }^{236}$ The imbalance in volition, in other words, would be grounds for holding shareholders liable for corporate torts.

Nina Mendelson's recent refinement further emphasizes the role that power imbalance plays in this discussion. She has suggested that only "controlling" shareholders should bear unlimited liability for corporate torts. ${ }^{237}$ The virtue of such a rule, she argues, is that it "would focus vicarious liability for corporate torts and tort-like statutory violations only on the shareholder

233. Id. at 1897; see also Elizabeth Warren, Making Policy with Imperfect Information: The Article 9 Full Prionity Debates, 82 CORNELL L. REV. 1373, 1389 (1997) ("II]n a full-priority system, secured creditors win, trade creditors and employees may win or lose, and tort victims lose."). Some have also observed that full priority is foreign to other similar systems and to other components of our own system. See id. at 1384.

234. Henry Hansmann \& Reinier Kraakman, Toward Unlimited Shareholder Liability for Corporate Torts, 100 YALE L.J 1879 (1991). Abrogating limited liability was not original to Hansmann and Kraakman. Others had previously made similar suggestions. See, e.g., Phillip I. Blumberg, Limited Liability and Corporate Groups, 11 J. CORP. LAW 573, 576 (1986); Alan Schwartz, Products Liability, Corporate Structure, and Bankruptcy: Toxic Substances and the Remote Risk Relationship, 14 J. LEGAL STUD. 689, 716-17 (1985) (advocating abolition of limited liability for "knowable [tort] risks"); Note, Should Shareholders Be Personally Liable for the Torts of Their Corporations?, 76 YALE L.J. 1190, 1196-1201 (1967) (advocating unlimited liability for closely-held corporations). See also Stephen Bainbridge, Abolishing Veil Piercing, 26 IOWA J. CORP. L. 479, 527-34 (2001) (suggesting permissibility of rule that allocates tort liability within a corporate group under enterprise liability theory).

235. See, e.g., Blumberg, supra note 234, at 576 ("'E]ven economists convinced of the utility of limited liability... concede that limited liability raises serious problems because it enables the enterprise to externalize its costs.").

236. Hansmann and Kraakman argue that shareholders should be liable to "involuntary" (low volition) creditors because-

The critical question is whether the victim was able, prior to the injury, to assess the risks she took in dealing with the firm and to decline to deal if those risks seemed excessive in comparison with the net advantages she otherwise derived from the transaction. In other words, the question is whether the victim can reasonably be understood to have contracted with the firm in substantial awareness of the risks of injury involved. Hansmann \& Kraakman, supra note 234, at 1921.

237. See Nina A. Mendelson, A Control-Based Approach to Shareholder Liability for Corporate Torts, 102 COLUM. L. REV. 1203, 1204-08 (2002). 
with the capacity to control the corporation.".238 A shareholder would exercise control for this purpose if the shareholder "possessed significant ownership and if it exercised 'actual control' over a corporation's activities by virtue of that ownership." ${ }^{239}$ An implication of Mendelson's proposal is that the imbalance of volition (and perhaps cognition) - the greater power wielded by the controlling shareholder-is the better basis for imposing liability. ${ }^{240}$

There is, of course, not complete identity between the debate about duty, on the one hand, and the discussions about full priority and unlimited shareholder liability, on the other. For example, discussions about personal property secured lending do not generally consider what it means for a corporation to be an entity, an undercurrent in the corporate law duty debate. The unlimited shareholder liability discussion spends a fair amount of time on its procedural implications, which is a less pressing problem in the duty context. It is nevertheless apparent that all three share.concerns about power imbalances that might flow from disparities in volition, cognition, and exit. It is therefore curious that none of these three sets of discourse have crosspollinated to consider a common concern, directorial duties to creditors.

\section{B. Volition, Cognition, and Exit: Contract and Creditors}

Virtually all commentators appear to agree that these kinds of power imbalances may be remedied by contract, understood in a certain way. Indeed,

\footnotetext{
238. Id. at 1206 .

239. Id. at 1272. Under Mendelson's proposal, shareholder capacity to control-as opposed to actual control-would appear relevant to the imposition of liability:

Exercise of "actual control" over even some aspects of corporate operations would be relevant to the question of whether the shareholder possessed the "capacity to control" the risky activity, even if the actual control was unrelated to the operations that resulted in a tort or statutory violation. The exercise of actual control by virtue of ownership suggests the ability to control the corporation in other respects, either by involvement in the selection of the corporation's board of directors, the exercise of authority over significant asset Id. sales, or participation in other major corporate decisions.
}

240. There are both theoretical and practical problems for any regime that seeks to impose unlimited shareholder liability. At a theoretical level, contractarians have observed that exposing shareholders to unlimited liability for corporate torts may simply deter the efficient deployment of capital. See, e.g., James J. White, Corporate Judgment Proofing: A Response to Lynn LoPucki's The Death of Liability, 107 YALE L.J. 1363, 1388 n.97 (1998). See generally EASTERBROOK \& FISCHEL, ECONOMIC STRUCTURE, supra note 111, at 41-44 (listing advantages of limited liability); Frank H. Easterbrook \& Daniel R. Fischel, Limited Liability and the Corporation, $52 \mathrm{U}$. CHI. L. REv. 89, 104 (1985) ("[M]odifying limited liability has its costs...."). At a practical level, courts that embrace a rule of unlimited shareholder liability would have to grapple with rules of apportionment, contribution, reimbursement, and indemnification, all of which would be made materially more difficult as the number of shareholders increased. See Hansmann \& Kraakman, supra note 234, at 1893-96 (addressing various procedural obstacles to unlimited shareholder liability). 
one way to view the debate about duty is not as if it were about corporate law or duty, per se, but instead about contract: When are persons in such a relationship that contract (however understood) can, or should, be deemed to express fully their rights, inter se? The more volition, cognition, and exit parties have, the closer they are to being viewed as contractual participants of equal dignity. ${ }^{241}$ Thus, to the extent a corporate stakeholder's rights are truly expressed by enforceable contracts, both contractarians and anticontractarians would seem content to excise or to abandon fiduciary duty. This may explain why both contractarians and anticontractarians appear to resist recognizing duties to creditors: In the eyes of these scholars, all creditors benefit from contract or other express rights at law that should protect them in ways that render fiduciary duty unnecessary.

Contractarians, for example, would probably argue that creditors should never benefit from a fiduciary duty. ${ }^{242}$ Recall that, to contractarians, fiduciary duty is not a meaningful or valuable concept, certainly not where a contract is as explicit as it usually is in the lending context. Unlike shareholders, the costs of specifying and monitoring borrower behavior are viewed as comparatively easy and cheap. Moreover, the whole point of most provisions in a credit agreement or bond indenture, for example, is to make explicit the rules that will maximize the likelihood that the lender will be repaid.

A typical recitation is thus:

[B]ondholders can draft elaborately detailed contracts to protect themselves from transactions that upset the original understanding between themselves and the firm. For example, bond indentures often limit the ability of an issuer to borrow, merge, pay dividends, repurchase stock, issue preferred stock, sell assets, or engage in transactions with affiliate companies. While these provisions do little to protect shareholders (and indeed might be deleterious to their interests), they do much to

241. Determining acceptable levels of volition and cognition may not be easy. As Victor Brudney has observed,

Demonstrating the degree of cognition and volition by parties that is adequate to support the concept of contract which has the implied legal consequences of autonomy requires solution of complex and intractable problems. First, it requires a theory or definition of the requisite "adequacy" of each party's knowledge and volition, and of the symmetrical availability to them of access to information and freedom of choice. Second, it requires some empirical showing in transactional or institutional contexts of the parties' "adequate" and symmetrical access to information and to alternatives for choice.

Brudney, Corporate Govemance, supra note 37, at 1405 (footnote omitted).

242. See Easterbrook \& Fischel, Contract and Duty, supra note 31, at 437 ("Managers owe fiduciary duties to equity investors, but not debt investors or employees, because these claimants can contract at low cost, while the costs of specification are prohibitively high for the residual claimants."). 
protect bondholders and other fixed claimants against wealth transfers by other corporate interests. ${ }^{243}$

To the contractarian, fiduciary concepts applied to corporate creditors add nothing, and may subtract a great deal, as they impose unnecessary costs on capital formation transactions. For example, those who would be directors would understandably be reluctant to agree to take on the job if they understood that they were liable as fiduciaries to corporate creditors. The costs imposed by these additional duties would flow, inevitably, back to shareholders in one of two ways. The corporation might have to pay these directors more in fees (to reflect the increased risks of service) or might have to pay more for increased insurance coverage to protect the directors. Alternatively, recognizing this form of duty would result in a net decrease in value to shareholders - and perhaps all corporate constituents-because if the corporation did not pay increased directors' fees or insurance premiums, "better" directors would choose not to serve. Thus, only lower quality directors would serve in these riskier positions. Shareholders would be deprived of the value of the service of better directors. ${ }^{244}$

Although anticontractarians seem willing to recognize a much wider role for duty in the corporate context than do contractarians, they, too, would likely balk at requiring directors of the distressed corporation to act as fiduciaries for corporate creditors. ${ }^{245}$ Rather, duties should run exclusively to or for the benefit of shareholders because shareholders are "unable to specify the opportunistic behavior against which [they] need[ ] protection" and lack the ability "to monitor the decisions being made under such restrictions or enforce compliance with those terms. ${ }^{1246}$ Widely dispersed bondholders, by contrast, may lack the leverage of a single bank, but they nevertheless enjoy contractual protections in a bond indenture that far exceed any contractual

243. Macey, Exclusive Beneficiaries, supra note 111, at 38. Although a typical statement of the contractarian position on fiduciary duties to creditors, it is, in itself, rather opaque. It is not, for example, clear how such provisions would actually prevent forbidden wealth transfers, other than by creating a cause of action for breach of contract.

244. There is, of course, an economic response to this. Modigliani/Miller should predict that, while recognizing a duty to creditors will result in an immediate cost to directors and shareholders, those costs should ultimately be offset by correlative reductions in the costs of credit. See Modigliani \& Miller, supra note 205. For example, if banks and bondholders understand that they benefit from a fiduciary duty in addition to the expressly negotiated terms of the lending contract, they should reduce the cost of borrowing to reflect the increased security of the loan. Equilibrium would, in other words, compensate for the cost associated with recognition of a duty.

245. Brudney, Contract and Duty, supra note 42 , at $611, n .41$ ("[M] anagement's agency or fiduciary obligations should run to stockholders rather than to the others.").

246. Id. at 612 . 
protections likely to benefit shareholders. ${ }^{247}$ Thus, although some have suggested that corporate bondholders might be appropriate beneficiaries of a fiduciary duty, the prevailing view seems to be that they should not. ${ }^{248}$

In short, neither contractarians nor anticontractarians would seem to believe that creditors should benefit from a fiduciary duty. ${ }^{249}$ The problem, however, is that this ignores the fact that not all claims of creditors arise by virtue of anything resembling a contract. The same power imbalances that plague other corporate relationships-and for which some would suggest duty is a remedy-also haunt certain creditors. Many creditors have comparatively low levels of volition, cognition, and exit and so would seem, on concerns about these things, to warrant the imposition of extracontractual duties.

\section{Low VCE Creditors}

Four categories of claimants may, for reasons of law or markets (or both), have low levels of volition, cognition, and exit, and so should benefit from some sort of fiduciary duty from directors of the distressed corporation: (i) tort creditors; (ii) certain terminated employees; (iii) taxing authorities; and (iv) certain trade creditors. ${ }^{250}$

\section{a. Tort Creditors}

Most literature on directors' duties to creditors assumes that creditors' claims always arise contractually. ${ }^{251}$ This is simply false. It would be difficult to say that tort creditors' claims are contractual in any meaningful legal sense. Most of those who claim to be victims of corporate torts would probably not characterize their rights as arising consensually. Indeed, for this reason, even a

247. Cf. Brudney, Corporate Bondholders, supra note 150, at 1829-30 (distinguishing limited volition of widely dispersed bondholders from that of single-source lenders such as banks).

248. See supra note 42 .

249. See Blair \& Stout, Team Production Theory, supra note 111, at 287.

Despite their many differences and disagreements, both the law and economics scholars and their progressive opponents share a common assumption: that, as a descriptive matter, American corporate law follows the shareholder primacy model. In other words, both camps believe that directors are controlled by, and owe extracontractual legal duties only to, shareholders.

Id. (footnote omitted). In fairness, this statement may implicitly apply only to directors of the corporation that is not in financial distress. It may be that anticontractarians would sympathize with the proposal here (to recognize directorial duties to low VCE creditors of the distressed corporation). To this point, however, none has made that argument.

250. This list is not exhaustive or exclusive. Indeed, it may not be especially accurate. It is intended simply to be illustrative.

251. See, e.g., Lin, supra note 2, at 1501-06. See generally sources cited supra note 34. 
proponent of limiting directors' duties might agree that tort creditors' lack of volition presents grounds for recognizing a duty. ${ }^{252}$

Nor will tort creditors have much cognition. They usually know little about the corporate tortfeasor, and may not even know much about the torts committed against them. Corporate officers and directors, by contrast, will usually know much more about the underlying tort, as well as the corporation's ability and willingness to satisfy tort judgments.

Finally, tort creditors have no meaningful way to exit the corporate relationship. Unlike the claims of banks and bondholders, rules on champerty and maintenance usually forbid the sale of personal injury tort claims. ${ }^{253}$ Even if these prohibitions were eliminated, it is not clear that a robust market for these claims would develop, as their value would likely be difficult to determine. ${ }^{254}$

252. Barondes, supra note 2, at 100 ("Tort claimants generally do not have the opportunity to negotiate for the right to benefit from a fiduciary duty imposed on directors. These involuntary creditors may present the most compelling situation calling for increased creditors' rights.").

253. See, e.g., ME. REV. STAT. ANN. tit. 17-A, \& 516(3) (West 1964) (making "champerty" a Class $E$ crime under Maine law). Sometimes assignments of intangible rights such as tort claims are held to be champertous because the assignee will acquire the right to sue for legal judgment. See, e.g., Johnson v. Sellers, 84 P.2d 744, 751 (Wyo. 1938) (hearing a claim that the purchase of land with the intent to bring suit should be voided as champertous). Similarly, the assignment of choses in action-that is, the sale of the right to sue to a disinterested party - often has been disallowed as entailing the champertous sale of a legal judgment. See, e.g., Roberts v. Holland \& Hart, 857 P.2d 492, 495-96 (Colo. Ct. App. 1993) (prohibiting assignment of legal malpractice claims, in part because such assignment would "promote champerty").

Champerty and maintenance would appear to be neither common nor especially potent causes of action, however. See Macke Laundry Serv. Ltd. P'ship v. Jetz Serv. Co., 931 S.W.2d 166, 171 n.1 (Mo. Ct. App. 1996) ("[T]he common law actions of [champerty and maintenance] are rare in modern times, having been replaced by the causes of action of abuse of process, wrongful initiation of litigation and malicious prosecution."). There are, not surprisingly, calls to eliminate or materially dilute these ancient doctrines. See, e.g., Donald L. Abraham, Investor-Financed Lawsuits: A Proposal to Remove Two Barriers to an Alternative Form of Litigation Financing, 43 SYRACUSE L. REV. 1297, 1303-08 (1992); Paul Bond, Making Champerty Work: An Invitation to State Action, 150 U. PA. L. REV. $1297,1297-98$ (2002). Of course, even if champerty and maintenance were eliminated, it is not clear that a robust market for tort claims would necessarily develop. In any event, it does not exist today.

254. An interesting claim by Charles Mooney may increase the pressure felt to recognize duties to tort creditors. In a recent article in the Stanford Law Review, Mooney argued that debtors that incur tort liability while in financial distress actually commit constructive fraudulent conveyances, at least under the current and generally accepted statutory formulations. See Charles W. Mooney, Jr., Judgment Proofing, Bankruptcy Policy, and the Dark Side of Tort Liability, 52 STAN. L. REV. 73, 75 (1999). This would be because the debt (tort liability) was incurred without receiving fair value in exchange, and while the corporation was insolvent. Thus, on this theory, many tort claims would be avoidable (meaning noncompensable) should a debtor enter bankruptcy. If Mooney's view is correct, then it is easy to imagine that tort creditors would have an even greater incentive to pursue the corporate-tortfeasor's directors. Without recourse to the debtor, the directors become an even more attractive source of recovery. 


\section{b. Terminated Employees}

Like tort creditors, certain terminated employees will suffer from comparatively low levels of volition, cognition, and exit. Low level, at-will employees who become creditors because their wages remain unpaid probably do not choose to be creditors in any meaningful sense. Nor are they likely to know much about the corporation or its willingness or ability to satisfy their claims. As with tort claims, there are typically prohibitions on the sale or hypothecation of wage claims.

The problem here will be that not all employee-creditors are similarly situated. Some employees will have more fully negotiated contracts than others. Many elite employees-corporate officers, for example-usually have fairly elaborate contracts that specify the rights and obligations of the parties. It is difficult to argue that the terminated chief executive officer suffered from a lack of volition or cognition, even if he cannot sell his unpaid-wage claims against the corporation to a third party. ${ }^{255}$

More difficult still will be the rights of organized employees that are parties to collective bargaining agreements. Collective bargaining agreements, like employment agreements for more elite employees, are usually fairly intensively negotiated, often by reasonably sophisticated representatives. While union members themselves may not always be especially sophisticated, their representatives should be. They will also often seek and obtain significant amounts of nonpublic information about the corporate employer in the course of negotiations. As to these employees, volition and cognition would likely be in fair supply. ${ }^{256}$

255. To the extent corporate officers are compensated with stock or options to purchase stock that is listed on a public market, the officers would be said to have exit. To the extent their shares cannot be sold or traded at a given point in time because, for example, the options have not vested or the Securities Act holding periods have not expired, the questions become more interesting.

256. There has nevertheless been no shortage of argument in favor of recognizing special-that is to say extracontractual-duties running from corporate employers to corporate employees. See, e.g., Kent Greenfield, The Place of Workers in Corporate Law, 39 B.C. L. REV. 283, 321-26 (1998) (arguing that market defects make contracts between labor and the corporation inefficient and criticizing the assumption that contract norms should be the basis for public policy since "the ability of parties to bargain is a function of their preexisting entitlements and wealth"); Kent Greenfield, The Unjustified Absence of Federal Fraud Protection in the Labor Market, 107 YALE L.J. 715, 717-22 (1997); Duncan Kennedy, Distributive and Patermalist Motives in Contract and Tort Law, with Special Reference to Compulsory Terms and Unequal Bargaining Power, 41 MD. L. REV. 563, 630 (1982); Marleen A. O'Connor, Restructuring the Corporation's Nexus of Contracts: Recognizing a Fiduciary Duty to Protect Displaced Workers, 69 N.C. L. REV. 1189 (1991); Marleen A. O'Connor, Promoting Economic Justice in Plant Closings: Exploring the Fiduciary/Contract Law Distinction to Enforce Implicit Employment Agreements, in PROGRESSIVE CoRPORATE LAW 219 (Lawrence E. Mitchell ed., 1995); Terry A. O'Neill, Employees' Duty of Loyalty and the Corporate Constituency Debate, 25 CONN. L. REV. 681, 685-86 (1993) (promoting fiduciary duty from employer to employee). 


\section{c. Taxing Authorities}

When taxes are not paid, taxing authorities become creditors. Although taxing authorities may not be the most sympathetic of the characters discussed thus far, they nevertheless often lack volition, cognition, and exit. Legislatures generally impose taxes without regard to the effect that they may have on a given taxpayer. While legislatures obviously choose to do this in some way, it would be difficult to say that they have done so in a way that rises to the level of contract required to displace a fiduciary duty. ${ }^{257}$ Certainly, taxing authorities know little about most creditors most of the time, at least until an audit or tax dispute. Nor are taxing authorities able to sell their claims into a secondary market. ${ }^{258}$

\section{d. Certain Trade Creditors}

Trade creditors-those who sell goods or services to a debtor on unsecured, short-term credit-present a challenging case for low VCE creditor status. On the one hand, they are often viewed as lacking the sophistication (that is, volition and cognition) of bondholders and institutional creditors. ${ }^{259}$ Smaller trade creditors may be at such a significant negotiating disadvantage with a debtor that they may be said to lack volition and cognition, especially if they are parties to output or long-term relational contracts. ${ }^{260}$ On the other hand,

There are, however, many who argue that we should recognize no such duties. See EASTERBROOK \& FISCHEL, ECONOMIC STRUCTURE, supra note 111, at 23 (stating that all parties to corporate "contract" can protect themselves through negotiation); Macey, Exclusive Beneficiaries, supra note 111, at 36, 42 (arguing that workers and other nonshareholder constituencies can protect themselves through contract or through the political process).

In a fundamental sense, this is simply a discrete elaboration of the nexus of contracts debate, with anticontractarians arguing that employees lack some combination of volition and/or cognition, and contractarians arguing that contract provides all the protection anyone reasonably needs.

257. Indeed, it is the involuntary nature of tax claims that caused Congress to give them priority once the taxpayer/debtor is in bankruptcy. See H.R. REP. NO. 95-595, at 190 (1977), reprinted in 1978 U.S.C.C.A.N. 5963, 6150 (taxing authorities are given priority because they are "involuntary" creditors).

258. This is not to say that secondary markets for tax claims will never develop or do not exist in primitive form now. See, e.g., Hill, supra note 206, at 1153, n.171 (discussing securitization of New York City's tax receivables "via a unique structure in which it essentially 'leased' out the receivables' collections rather than sold them because it was subject to regulations that would have required cumbersome approvals for an outright sale"). Outside the tax context, of course, states-as-creditors would appear to have ample opportunities for exit. A market could develop for tax claims, as it has for claims of states arising under the Tobacco Master Settlement Agreement. See NATIONAL CENTER for Policy analysis, SeCuritization Puts TOBacco Settlement Money at Risk, http://www.ncpa.org/iss/sta/2003/pd031 103a.html (last viewed Mar. 18, 2003).

259. See Barondes, supra note 2, at 88; see also Harvey, supra note 42, at 1025 n.8.

260. See generally lan R. Macneil, Relational Contract Theory: Challenges and Queries, 94 Nw. U. L. REV. 877 (2000) (discussing unique problems of relational contracts). 
some are in fact quite sophisticated-Martha Stewart, for example, is a trade creditor of Kmart. ${ }^{261}$

The best argument against placing trade creditors in the low VCE category is that market mechanisms may protect them. First, they should be able to refuse to sell to the debtor if they know that the debtor is in distress, although this may cause significant pain to the small creditor. Second, unlike tort and tax claims, there is a fairly well established market for trade claims. That said, the secondary market for these claims tends to discount them significantly, suggesting that the market may not be such an effective protection after all. ${ }^{262}$

These categories of creditors are intended to be illustrative, not definitive. There may well be tort creditors who have high levels of volition and cognition, even though they may lack a right of exit. It would be difficult, for example, to claim that Pennzoil, a tort creditor of Texaco, was a low VCE creditor. The same can be said for all of these categories. Nor are the categories exhaustive. I have undoubtedly missed some; others, unanticipated today, may arise in the future. The critical issue is not the nature of the claim, but the nature of the claimant, and its relationship to the corporate debtor.

\section{High VCE Creditors}

Low VCE creditors stand in contrast to the more obviously contractual creditors of the corporate debtor. High VCE creditors may include banks, commercial paper purchasers, or bondholders (the latter of whom have received more consideration on the fiduciary duty question than any others). These creditors, by and large, have contracts that have been heavily negotiated and that tend to express most of the important rights of the parties; if they did not haggle over each covenant, they at least have levels of volition, cognition, and exit that would make it difficult to believe that they need the protection of directorial duties.

Banks, for example, typically demand and receive extraordinary amounts of information about their borrowers. ${ }^{263}$ This information then forms the basis of the many representations, warranties, and covenants of the borrower in the loan agreement. All of these terms are usually heavily negotiated; if they are not, the bank, rather than the borrower, usually dictates the terms. Moreover, there

261. See Will Martha Dump Kmart?, http://money.cnn.com/2002/01/17/ceos/v_martha_stewart/ index.htm (Jan. 17, 2002) ("Kmart's best-known supplier is Martha Stewart, whose housewares and other products have been a big draw for Kmart shoppers, pulling in \$1.5 billion last year.").

262. For a discussion of limits on the marketability of trade claims, see Barondes, supra note 2 , at $90-98$.

263. I include in this category nonbank lenders that perform a substantially similar lending function, such as General Electric Capital Corporation. 
is a fairly robust secondary market for these loans, whether in whole or as participations. Banks therefore have a ready exit from the corporate relationship. ${ }^{264}$

Bondholders, too, often enjoy high levels of volition, cognition, and opportunities for exit. Publicly traded bonds are rated through a fairly sophisticated process controlled by "nationally recognized statistical rating organization[s]," such as Moody's and Standard \& Poor's. ${ }^{265}$ Ratings do not, of course, guarantee payment. They are simply an assessment of the creditworthiness of the issuer of the bonds. ${ }^{266}$ Nevertheless, ratings, along with the significant amounts of information provided in order to register publicly traded bonds with the Securities and Exchange Commission, assure a fairly high level of disclosure, which in turn promotes cognition. ${ }^{267}$ The fact that bonds are usually traded publicly means, by definition, that there is a meaningful method of exit.

As suggested above, trade creditors sometimes present a somewhat more difficult case for low VCE creditor status. It is likely that the larger, more sophisticated trade creditors- the General Electrics, IBMs, and Martha Stewarts of the world-probably do not need duty. ${ }^{268}$ They all have the benefit of contracts that have been negotiated with some care by informed professionals. Often, they have access to a secondary market in the event the debtor commences a Chapter 11 case that would have more value for them than for other, smaller trade creditors, because their creditworthiness would make the claim itself a less risky purchase. ${ }^{269}$

264. Often, exit will be provided by access to the securitization market. See 1 SECURITIZATION OF FinANCIAL ASSETS \& 3.09, at 3-52 to 3-53 (Jason H. P. Kravitt ed., 2d ed. 1999 \& 2000-1 Supp.) (discussing sales of loans into securitization transactions).

265. See Steven L. Schwarcz, Private Ordering of Public Markets: The Rating Agency Paradox, 2002 U. ILL. L. REV. 1, 4-7 (2002).

266. Id. at 6 ("A rating is an assessment of the likelihood of timely payment on securities.") (citing Salomon B. Samson \& Gail I. Hessol, Ultimate Recovery in Ratings: A Conceptual Framework, S\&P CREDIT WEEK, Nov. 6, 1996, at 25).

267. The Metropolitan Life court began its analysis by observing that the plaintiff bondholders were "among the country's most sophisticated financial institutions, as familiar with the Wall Street investment community and the securities market as American consumers are with the Oreo cookies and Winston cigarettes made by defendant RJR Nabisco, Inc." See Metro. Life Ins. Co. v. RJR Nabisco, Inc., 716 F. Supp. 1504, 1505 (S.D.N.Y. 1989).

268. Until recently, it appeared that Stewart had been able to fend for herself in the Kmart bankruptcy. See Kmart to Keep Martha Stewart, Other Lines, http://www.clickondetroit.com/det/ news/stories/news-131297720020320-060343.html (Mar. 20, 2002) ("The retailer is allowed to continue its licensing agreements and pay outstanding debts to the five major brands. Kmart owes nearly $\$ 132,000$ to Kathy Ireland, $\$ 1.5$ million to Jaclyn Smith supplier GH Productions and $\$ 12.3$ million to Martha Stewart. The five brands account for roughly $\$ 1.7$ billion in annual gross sales, Kmart said."). In April 2003, however, the U.S. District Court for the Northern District of Illinois reversed the Bankruptcy Court orders in the Kmart case approving these payments. See Capital Factors, Inc. v. Kmart Corp., 291 B.R. 818, 825 (N.D.Ill. 2003).

269. For a discussion of trade creditors, see supra Part III.B.1.d. 
Nor would low VCE creditors be any of the other more sophisticated, volitional creditors that a corporate debtor may have. These high VCE creditors may include licensors, lessors, insurers, personal guarantors, holders of convertible preferred stock, etc. The key here, as with determining who should be treated as a low VCE creditor, is to focus not on the kind of claim-bond or tort-but instead on the circumstances and relationships giving rise to it.

\section{IMPLICATIONS AND FURTHER INQUIRY}

Recognizing duties to creditors based on comparative levels of volition, cognition, and exit has a number of implications, some likely to be more welcome than others. Those that are less welcome may be appropriate subjects for further study.

\section{A. Virtues}

The virtues are fairly straightforward. First, if directors of the distressed firm owe duties only to low VCE creditors, they should no longer have to worry about duties to high VCE creditors. A casual reader of this Article may think I have advocated for the creation of new duties. Nothing, however, could be further from the truth. As discussed above, it is amply clear that courts will hold directors liable to creditors for breach of duty. I suggest that, in the future, they should be more thoughtful about which creditors should benefit from fiduciary duties.

This may, in turn, effect a kind of efficiency in two ways. First, it would deter high VCE creditors from relying on duplicative remedies (contract plus duty plus statutory creditors' remedies). Second, it may free courts from the pressure they seem to feel to pursue the apparently inefficient path of creditor maximization. Most courts confronted with a claim that directors breached a fiduciary duty to creditors appear to follow this path, notwithstanding its apparent inefficiency, which may mean that directors should be excessively cautious in governing the distressed firm. ${ }^{270}$ In either case, high VCE creditors usually contract for all the maximization they want; they do not need judicial intercession to maximize firm value for their benefit.

Finally, and more subtly, orienting duty in this way relaxes the role of priority, and ties duty to its normative base. Although priority does matter in the discussion of duty, it is not apparent that it is the best or only basis for treating directors as fiduciaries for creditors. Rather, the power imbalances that

270. For a discussion of the inefficiency of creditor maximization, see supra Part I.B.2.c. 
generally give rise to duties—differences in volition, cognition, and exit-should govern the vector of duties, even to creditors.

B. Further Inquiry

It is equally clear, however, that the proposal contained in this Article raises several questions, some of which may warrant further inquiry. A short list follows.

\section{The Proper Role of Priority and Contract}

If duties to creditors of the distressed firm should flow largely (or exclusively) based on volition, cognition, and exit, what should remain of priority and contract? This breaks down into two subsidiary questions. First, low VCE creditors will always have these attributes, even if the firm is solvent. Why should directors owe duties to them only when the firm is distressed? And by a parity of reasoning, shouldn't duties to shareholders be sliced along similar lines? Sophisticated institutional shareholders, for example, have high levels of volition, cognition, and exit; widows and orphans do not. Should we not, on the theory advanced here, say that institutional shareholders (like banks and bondholders) deserve no fiduciary duty?

Second, certain low VCE creditors benefit from special priority rights, under the Bankruptcy Code and other bodies of law. Under the Bankruptcy Code, state and federal tax claims, for example, often enjoy priority in payment over other claims ${ }^{271}$ and cannot be discharged. ${ }^{272}$ I have argued elsewhere that shifts in sovereign immunity doctrine may add ammunition to the arsenal of privileges that states enjoy against a debtor in bankruptcy, effectively giving state claims rights equivalent to priority. ${ }^{273}$ Similarly, some states provide that shareholders may be personally liable for unpaid wages. ${ }^{274}$

Third, if priority should continue to matter, what directorial duties should run to holders of other, more specialized, rights in a corporate debtor? Should the unsophisticated holder of highly illiquid preferred stock benefit

271. See 11 U.S.C. $\$ 507(a)(8)$ (2002) (giving priority to claims of "governmental units," for certain classes of taxes). Those classes of taxes include income taxes, id. $\S 507(\mathrm{a})(8)(\mathrm{A})$, property taxes, id. \&507(a)(8)(B), employment taxes, id. §507(a)(8)(D), and excise taxes, id. \&507(a)(8)(E).

272. Id. \$523(a)(1) ("A discharge under section ... 1141 ... of this title does not discharge an individual debtor from any debt ... for a tax.").

273. See Jonathan C. Lipson, Fighting Fiction with Fiction-The New Federalism in (A Tobacco Company) Bankruptcy, 78 WASH. U. L.Q. 1271 (2000).

274. For example, New York imposes liability on shareholders for employee wage claims if the corporation fails to satisfy those claims. N.Y. BUS. CORP. LAW $\$ \$ 103 \& 630$ (McKinney 1986). See also Grossman v. Sendor, 392 N.Y.S.2d 997, 999 (Sup. Ct. 1977). 
from a fiduciary duty? What about creditors with security interests in the debtor's property? Neither type of rights holder would be among the cast of characters that is typically said to benefit from a fiduciary duty (common shareholders and unsecured creditors). Yet, they too, could suffer from imbalances of volition, cognition and exit.

The questions as to what should remain of priority and contract are legitimate, and deserve further analysis. Preliminary answers might flow from the observation that priority should matter; it should simply not be the only thing that matters in understanding directorial duties to creditors. How much it should matter remains to be seen. So, too, for contract; in the case of institutional or preferred shareholders holding for their own account, the answer may be that their high levels of volition, cognition, and exit render duty unnecessary.

\section{Problems with Volition, Cognition, and Exit}

While volition, cognition, and exit are important considerations in recognizing duty, they bring their own problems with them. First, and most obviously, the terms volition and cognition are heavily freighted with complex implications. As noted in the Introduction, ${ }^{275} \mathrm{I}$ use these terms in a common sense way, because it seems reasonably clear that, while these terms are quite nuanced, recognizing the need to make distinctions based on them requires little subtlety. That is not to say, however, that the very good work being done on volition and cognition in their deeper senses is inapplicable here. ${ }^{276}$ Indeed, those studies may bring insight to the problems addressed here.

Second, it may be difficult-ex ante or ex post-to determine whether these power imbalances exist and, if so, whether they are sufficient to justify the imposition of a fiduciary duty. A related problem is that these concerns effectively trade on weakness, perhaps encouraging creditors to exchange their wolf's clothes for those of the sheep. It is, as others have observed, troubling that our law frequently asks those who seek its protection to make themselves out to be imbeciles or incompetents. ${ }^{277}$ This is, in many respects, a problem intrinsic to equitable rights and remedies: We frequently ask judges to make difficult decisions without the guidance of clear rules, but based instead on their overall surmise of the parties' relationships and behavior. As such, the

275. See note 4, supra.

276. See, e.g., Carl S. Bjerre, Secured Transactions Inside Out: Negative Pledge Covenants, Property and Perfection, 84 CORNELL L. REV. 305, 353 (1999); Larry T. Garvin, Adequate Assurance of Performance: Of Risk, Duress, and Cognition, 69 U. CoLO. L. REV. 71 (1998).

277. See, e.g., Duncan Kennedy, Form and Substance in Private Law Adjudication, 89 HARV. L. REV. 1685 (1976). 
nature and role of volition, cognition, and exit will remain important areas of further inquiry.

Third, I have so far been silent about the comparative levels of volition, cognition, and exit needed for imposition of a duty. More to the point, I have avoided stating whether these three things should be understood conjunctively or disjunctively. It is certainly possible to imagine a creditor with a high level of volition but no right of exit (perhaps taxing authorities). Similarly, it is easy to imagine a creditor with high cognition but no volition (the Pennzoil/Texaco example). Should the failure to establish all three-volition, cognition, and exit-free directors of worrying about duties as to this creditor?

These, too, are matters for further inquiry, although I am inclined to be restrictive, and treat volition, cognition, and exit conjunctively (meaning that duty would run only to creditors lacking all three).

\section{Contingent and Unliquidated Claims}

A third area for further inquiry involves claims that are contingent and/ or unliquidated. These are claims (often in tort) that may exist in the present, because the debtor has already committed the tort, but which have not yet made themselves manifest. The Bankruptcy Code and most relevant state statutes define "claim" in the broadest possible way, to include rights against a debtor "whether or not such right is reduced to judgment, liquidated, unliquidated, fixed, contingent, matured, [or] unmatured ...."278 Indeed, the Bankruptcy Code (among others) expressly contemplates the resolution of such claims in the bankruptcy process, providing mechanisms whereby claims that are contingent and/or unliquidated may be resolved notwithstanding their uncertain state. ${ }^{279}$ Examples from the real world have included

278. 11 U.S.C. $\$ 101(5)(A)(2000)$. The uniform statutes that proscribe fraudulent conveyances contain similarly broad definitions. See, e.g., UNIF. FRAUDULENT CONVEYANCE ACT $\$ 1$ (1999) (defining "debt" to "include[ ] any legal liability, whether matured or unmatured, liquidated or unliquidated, absolute, fixed or contingent"); UNIF. FRAUDULENT TRANSFER ACT § 1(3) (1984) (defining "claim" to "mean[ ] a right to payment, whether or not the right is reduced to judgment, liquidated, unliquidated, fixed, contingent, matured, unmatured, disputed, undisputed, legal, equitable, secured, or unsecured").

279. Bankruptcy Code $\$ 502$ (c)(1), for example, permits a bankruptcy court to estimate contingent and unliquidated claims for allowance purposes. 11 U.S.C. \$ 502(c)(1) (2002). Bankruptcy courts do not generally have jurisdiction, however, to determine liability for personal injury tort or wrongful death claims. See 28 U.S.C. $\$ 157$ (b)(2)(B) (2000) (permitting bankruptcy courts to estimate claims for certain purposes, "but not the liquidation or estimation of contingent or unliquidated personal injury tort or wrongful death claims against the estate for purposes of distribution in a [bankruptcy] case."). Similarly, bankruptcy courts lack jurisdiction to try such claims. See §157(b)(5) ("The district court shall order that personal injury tort and wrongful death claims shall be tried in the district court in which the bankruptcy case is pending, or in the district court in the district in which the claim arose, as determined by the district court in which the bankruptcy case is pending."). 
liability arising from asbestos, ${ }^{280}$ breast implants, ${ }^{281}$ and the Dalkon Shield birth control device. ${ }^{282}$ Bankruptcy scholars recognize that these long tail claims present some of the greatest challenges to both bankruptcy policy and tort remedies. ${ }^{283}$

But before bankruptcy, it will often be the case that the corporation has already incurred significant contingent tort liabilities. Indeed, such claims are often the principal reason for financial distress. ${ }^{284}$ Under Credit Lyonnais, directors would presumably owe duties of care and loyalty to these tort creditors as the corporation becomes financially distressed, yet the directors may not even know that the corporation is liable to these creditors. Courts would therefore have to fashion some protection for directors of the corporation that is discovered, after the fact, to have had contingent or unliquidated tort liabilities. It may, for example, be appropriate to conclude that if the liability was not, with the exercise of reasonable prudence, discoverable by the directors, then no duties should have been owed by the directors to the tort claimants. On the other hand, directors of the distressed corporation that know, or have reason to know, that the corporation has engaged in tortious conduct should be said to owe duties of care and loyalty to those tort creditors.

There are, however, sometimes ways around these prohibitions. See, e.g., Menard-Sanford v. Mabey (In re A.H. Robins Co.), 880 F.2d 694, 699 (4th Cir. 1989) (describing Dalkon Shield claims estimation hearings).

280. See, e.g., In re Johns-Manville Corp., 36 B.R. 743, 744 (Bankr. S.D.N.Y. 1984), aff d, 52 B.R. 940 (S.D.N.Y. 1985); Owens-Illinois, Inc. v. Rapid Am. Corp. (In re Celotex Corp.), 124 F.3d 619, 622 (4th Cir. 1997); In re Eagle-Picher Indus., 197 B.R. 260, $263-64$ (Bankr. S.D. Ohio 1996); In re Keene Corp., 208 B.R. 112, 113 (Bankr. S.D.N.Y. 1997); see also Official Committee of Asbestos Personal Injury Claimants, ex rel. Estate of W.R. Grace \& Co. v. Sealed Air Corp. (In re W.R. Grace \& Co.), 281 B.R. 852 (Bankr. D. Del. 2002) (discussing the difficulty of valuing contingent and unliquidated asbestos claims for purposes of determining the solvency of the debtor).

281. See In re Dow Corning Corp., 211 B.R. 545, 551-54 (Bankr. E.D. Mich. 1997).

282. See In re A.H. Robins Co., 88 B.R. 742, 747 (E.D. Va. 1988), aff'd, 880 F.2d 694 (4th Cir. 1989), cert. denied, 493 U.S. 959 (1989).

283. See, e.g., Daniel L. Keating, Getting a Handle on Late-Manifesting Claims: A Comment, 72 WASH. U. L.Q. 1095, 1095 (1994) (arguing that contingent unliquidated claims in large Chapter 11 reorganizations present "a problem of timing and information that defies any neat solution"); Alan N. Resnick, Bankruptcy as a Vehicle for Resolving Enterprise-Threatening Mass Tort Liability, 148 U. PA. L. REV. 2045, 2081 (2000) ("Probably the most difficult challenge facing courts presiding over mass tort cases involving long-tail future claims is a determination or estimation of the aggregate amount of such claims.... Estimating future claims is especially complex when underlying liability, in addition to the magnitude of harm, is disputed.").

284. In an empirical study of the forty-three largest reorganizations of the 1980s, LoPucki and Whitford found that for two of the companies they studied (Manville Corporation and Smith International) more than two-thirds of the unsecured debt was involuntary. See Lynn M. LoPucki, The Unsecured Creditor's Bargain, 80 VA. L. REV. 1887, 1896 n.41 (1994). 


\section{Remedial Redundancy}

Another problem is suggested by the apparent redundancy of remedies. ${ }^{285}$ Creditors benefit from a wide range of causes of action against a corporate debtor and against those who receive the debtor's property when the debtor is financially distressed. These actions include fraudulent conveyance, preference, unjust enrichment, unlawful dividence distribution, and so on. Why is duty necessary or useful?

A partial response might first observe that the many courts that have found directors liable for breach of duty to creditors appear not to have been deterred by the possibility of remedial redundancy. ${ }^{286}$ These courts may have understood that while breach of duty claims sometimes overlap with avoidance actions, the identity is not one-to-one. In Healthco, for example, certain directors were liable for breach of the duty of care even though they did not themselves receive anything from the transaction that gave rise to both fraudulent conveyance and breach of duty of loyalty claims. Nor could they have been liable under any avoidance theory, as such, since they did not receive the debtor's property - they merely approved the transactions. ${ }^{287}$ True, they may have been liable on an aiding and abetting theory. But, this simply proves the civil procedure axiom that a single transaction or occurrence may give rise to multiple causes of action.

There may well be some identity between avoidance actions and loyalty claims-if the director pillaged the company, he would flunk both sets of rules. There is, however, no necessary connection between avoidance actions and breach of duty of care claims. This is because the duty of care can be breached without any transfer of property at all. For example, if the directors do nothing in the face of impending disaster, they may well be negligent. They may not,

285. See, e.g., Lin, supra note 2, at 1514-15 ("Because creditors can seek redress under fraudulent conveyance or voidable preference law should someone try to seek illicit priority, a cause of action based on breach of fiduciary duty seems to add little to the current statutory scheme.").

286. In Healthco, for example, the directors were sued under both breach of duty and other theories, including unjust enrichment. See Brandt v. Hicks, Muse \& Co. (In re Healthco Int'l, Inc.), 208 B.R. 288, 311 (Bankr. D. Mass. 1997) ("A claim for unjust enrichment exists against a fiduciary for breach of fiduciary duty.").

287. Healthco, 208 B.R. at 303 ("A director's obligation of loyalty to his corporation is not, however, limited to subordinating his own financial interests to those of the corporation. It necessarily encompasses a duty not to place another director's financial interest above the interests of the corporation."). A curiosity of Healthco is that Judge James Queenan appears to have used the very device that should have cleansed the transaction-independent director approval-against those allegedly independent directors. See id. at 303-04 (discussing the inapplicability of "cleansing" provisions under DEL. CODE ANN. tit. 8 \$ 144). 
however, have caused the corporation to transfer property that could be recaptured by an avoidance action. Here, only duty would provide a remedy. ${ }^{288}$

Nor would duty function in the boardroom in the same manner as avoidance actions. Directors of a corporation that cause it to engage in a constructive fraudulent conveyance, for example, will only be liable if they receive corporate property. If they do not receive corporate property-but simply approve a transaction that is both stupid and bad-they would not be personally liable under fraudulent conveyance or other avoidance action theories. If, however, the directors know that duty exposes them to liability, they should think twice about the potentially adverse consequences of the transaction. Duty, in other words, would deter more than director self-aggrandizement; it would also affirmatively compel directors to be prudent. As in other contexts, duty would be a gap-filler, channeling behavior in the absence of express provisions of contract or rules of law. ${ }^{289}$

Nevertheless, like all creditors, low VCE creditors do enjoy remedies apart from contract and priority (e.g., fraudulent conveyance) that may render duty duplicative. The important question here will be whether duty provides meaningful supplemental protection for low VCE creditors. How duty should interact with these other protections may warrant further consideration.

\section{The Special Problem of Securities Fraud}

Securities fraud (and similar misconduct) will also give rise to special problems, and may warrant further inquiry. It may be that bondholders sue directors and officers of the issuer not only for violations of the securities laws, but also for breach of fiduciary duties. On the approach offered here, they should easily show the absence of volition and cognition. Fraud certainly

288. Laura Lin has nevertheless argued that there is virtually a complete identity between breach of duty claims and avoidance actions. "All of the decisions in which the courts have allowed creditors to recover for breach of fiduciary duty have involved directors of an insolvent corporation diverting corporate assets for the benefit of insiders or preferred creditors." Lin, supra note 2, at 1513. Although an important part of the story, it is-and was at the time she wrote this-not so. The Weiss case, discussed at notes 65-73, supra, imposed liability on directors for breach of the duty of care simply because they could not obtain a sufficiently high price for corporate assets. See N.Y. Credit Men's Adjustment Bureau v. Weiss, 110 N.E.2d 397 (N.Y. 1953). See also discussion at note 73, supra.

289. Although it appears that Lin believes creditors should never benefit from directors' duties (absent an express contract), she correctly recognizes their power to create boardroom incentives:

[A] fiduciary duty gives creditors an additional remedy by granting them the right to recover against directors who failed to exercise due care and allowed other corporate insiders to misappropriate corporate assets at the creditors' expense. This rule would give directors proper incentives to keep themselves informed of the corporation's affairs and to monitor the firm's activities.

Lin, supra note 2 , at 1516. 
impairs exit, by causing reduced ratings, dampening the market for these bonds.

The problem here is that breach of duty claims in securities fraud actions are typically vestigial because they do not provide the most powerful class of rights and remedies against corporate stewards. Powerful rights and remedies arising upon securities fraud come not from fiduciary law, but instead from federal securities laws. ${ }^{290}$ Whether securities fraud plaintiffs are also low VCE creditors-and whether that should matter-may warrant further analysis.

\section{CONCLUSION}

This Article has looked beneath the surface of the claim that directorial duties should run to creditors when a firm is distressed. It has suggested that duty currently appears to be a function of priority in right of payment. Priority, however, is an incomplete basis for recognizing duty. Rather, a better approach is to understand that duty is a response to imbalances of power. In the corporate context, these imbalances of power are expressed as disparities of volition, cognition, and exit. In this recognition, we both prevent windfalls to creditors who warrant no duty, and focus duty more carefully on those who need it most.

290. See, e.g., Securities Exchange Act § 10(b), 15 U.S.C. \$ 78j(b) (1982); Rule 10b-5, 17 C.F.R. $\$ 240.10$ b-5 (1988).

Complicating matters is the fact that $\S 510$ (b) of the Bankruptcy Code subordinates claims arising from the "rescission of a purchase or sale of a security of the debtor .... [or] for damages arising from the purchase or sale of such a security ...." 11 U.S.C. $\$ 510$ (b) (2000); see Allen v. Geneva Steel Co. (In re Geneva Steel Co.), 281 F.3d 1173, 1182-83 (10th Cir. 2002) (using §510(b) to subordinate claims arising from post-investment fraud). The claim arising from a bond, itself, would not be subordinated by virtue of the securities fraud. See id. at 1177. The claim arising from the fraud, however, would. Id. at 1182-83. 